UNIVERSIDADE DE SÃO PAULO

ESCOLA DE ENFERMAGEM

ISABEL COMASSETTO

TEMPOS DIFÍCEIS: FAMILIARES VIVENCIANDO $O$ PROCESSO DE MORRER NO MUNDO DO HOSPITAL

2014 
ISABEL COMASSETTO

\section{TEMPOS DIFÍCEIS: FAMILIARES VIVENCIANDO O PROCESSO DE MORRER NO MUNDO DO HOSPITAL}

(Versão Corrigida, a original se encontra disponível na Biblioteca da Escola de Enfermagem da USP)

Tese apresentada ao Programa Interunidades de Doutoramento em Enfermagem da Escola de Enfermagem da Universidade de São Paulo e Escola de Enfermagem de Ribeirão Preto da Universidade de São Paulo - Curso Doutorado Interinstitucional entre a Universidade de São Paulo e Universidade Federal de Sergipe tendo como associada a Universidade Federal de Alagoas, para obtenção do título de Doutor em Ciências.

Área de Concentração: Enfermagem

Orientadora: Prof. ${ }^{a}$ Dr. ${ }^{-a}$ Ana Cristina Mancussi e Faro 
AUTORIZO A REPRODUÇÃO E DIVULGAÇÃO TOTAL OU PARCIAL DESTE TRABALHO, POR QUALQUER MEIO CONVENCIONAL OU ELETRÔNICO, PARA FINS DE ESTUDO E PESQUISA, DESDE QUE CITADA A FONTE.

Assinatura:

Data:

Catalogação na Publicação (CIP)

Biblioteca "Wanda de Aguiar Horta"

Escola de Enfermagem da Universidade de São Paulo

Comassetto, Isabel

Tempos difíceis: familiares vivenciando o processo de

Morrer no mundo do hospital / Isabel Comassetto. - São Paulo, 2014.

$127 \mathrm{p}$.

Tese (Doutorado) - Escola de Enfermagem da Universidade de São Paulo.

Orientadora: Prof ${ }^{\mathrm{a}}$. Dr ${ }^{\mathrm{a}}$. Ana Cristina Mancussi e Faro

Área de concentração: Enfermagem

1. Morte 2. Família 3. Paciente terminal I. Título. 
Nome: Isabel Comassetto

Título: Tempos difíceis: familiares vivenciando o processo de morrer no mundo do hospital

Tese apresentada ao Programa de Pós-Graduação Interunidades EEUSP-EERP da Escola de Enfermagem da Universidade de São Paulo para obtenção do título de Doutora em Ciências.

Aprovada em: 1

\section{Banca Examinadora}

Prof. Dr: Instituição:

Julgamento: Assinatura:

Prof. Dr: Instituição:

Julgamento: Assinatura:

Prof. Dr: Instituição:

Julgamento: Assinatura:

Prof. Dr: Instituição:

Julgamento: Assinatura:

Prof. Dr: Instituição:

Julgamento: Assinatura: 


\section{DEDICATÓRIA}

Dedico este trabalho

Ao mew marido, Reinaldo

Mensfithos, Nathatia e Vitor

Com quem compartithei a minha trajetória e entenderam os meus momentos de ausencia. 


\section{AGRADECIMENTOS}

À Escola de Enfermagem da Universidade de São Paulo - EEUSP, pela oportunidade concedida para a realização deste curso.

À Universidade Federal de Alagoas - UFAL, pela possibilidade concedida para a reatização deste curso. Em especial a professora Regina María dos Santos pelo apoio e confiança.

À Coordenação de Aperfeiçoamento de Pessoal de Nivel Superior - CAPES, edital 005/2009 Ação Novas Fronteiras da CAPES/MEC.

À professora Ana Cristina Mancussi e Faro, pelo acothimento e orientação, pela confiança e presença florida em cada dia compartithado, tão essencial para tornar minha trajetóría mais harmoniosa.

À professora Miriam Aparecida Barbosa Merighi que me norteou para o caminho da fenomenologia.

Aos familiares, sujeitos deste estudo, que compartitharam suas vivencias, contribuindo para a concretização deste estudo.

A toda a minha familia pelo incentivo e apoio.

À Ana Paula Nogueira de Magalhães com quem compartithei sabores e saberes em um dos momentos mais dificeis do meu caminhar.

A todos os professores deste programa pela contribuição e auxítio na minha formação profissional, em especial agradeço a professora Dulce María Rosa Gualda sempre tão atenciosa e acolhedora.

A todos que colaboraram na construção deste estudo, seja colaborando na elaboração das ideias, seja dedicando-me sua amizade, atenção e confíança na minha capacidade. 
Não cuides nem das horas nem dos anos, mas do instante de agora cuida apenas. Cuida de cada um deles, vive- $\sigma$ todo, como se $\sigma$ único fosse, ou o derradeiro.

Não é de horas ou de anos que a existência no tempo, rosa plena, desabrocha para cair, no final, emurchecida, do próprio tédio de existir, cansada.

São longos of instantes, curta a vida: um minuto não passa quase nada enquanto bem depressa correm os anos.

Dosanos, pois, não cuides, nem das horas; cuida só deste instante, único e lindo, em que o melhor de ti palpita à espera.

(Daniel Lima) 
Comassetto I. Tempos difíceis: familiares vivenciando o processo de morrer no mundo do hospital [tese]. São Paulo: Escola de Enfermagem, Universidade de São Paulo; 2014.

\section{RESUMO}

Introdução: O processo de morrer é uma experiência vinculada a considerações significativas para a existência do ser, principalmente quando sobrevêm no contexto familiar. Objetivo: compreender a experiência do familiar de pacientes em fase terminal de vida, que enfrentam o processo de morrer no mundo do hospital. Método: Com esta proposta, optei por realizar uma pesquisa qualitativa, norteada pela Fenomenologia existencial de Martin Heidegger. Os sujeitos do estudo foram 15 familiares que estavam acompanhando seus pacientes adultos, em fase terminal de vida, que enfrentavam o processo de morrer em um hospital universitário de Maceió, Alagoas. Os depoimentos foram obtidos por meio de entrevista, no período de fevereiro a maio de 2013, a partir da seguinte questão norteadora: "Conte-me como é para você vivenciar a situação do seu familiar atualmente". Resultados: Da análise dos depoimentos dos familiares emergiram três estruturas, denominadas unificações ontológicas: Manifestação de Angústia dos familiares, que envolve a possibilidade do ser assumir-se como um ser-para-a-morte; Manifestação do Cuidado e da Solicitude, que compreende o momento de cuidar como algo significativo na existência; e Ser-aí no mundo do hospital, que compreende o ser lançado no mundo onde o limite entre a vida e a morte é tão estreito. Conclusões: A compreensão do fenômeno vivido por esses familiares permitiu apreender a dimensão do sofrimento relativo à condição de estar-nomundo cuidando no processo de morrer. Aponta a relevância do tema MORTE na formação dos profissionais de saúde, sinalizando importância da reflexão dessa temática, para desenvolver uma assistência que seja compatível com a situação vivenciada pelos familiares diante da terminalidade.

PALAVRAS-CHAVE: Atitude Frente a Morte. Família. Paciente Terminal. 
Comassetto I. Tough times: families experiencing the death process in the hospital setting [thesis]. São Paulo: School of Nursing, University of São Paulo; 2014.

\begin{abstract}
Introduction: The death process is an experience linked to significant considerations to the existence of the being, mainly when they take place in the family context. Objective: To understand the experience of family members of terminal patients, who face the death process in the hospital setting. Method: A qualitative study was developed, in light of the existential phenomenology of Martin Heidegger. Study subjects were 15 family members who were accompanying adult terminal patients, who faced the death process at a teaching hospital in Maceió, Alagoas. The statements were obtained by means of interviews, between February and May of 2013, based on the following guiding question: "What is it like for you to experience the current situation of your relative?" Results: The analysis of the statements of the family members generated three structures, named ontological unifications: Manifestation of anxiety by the family members, involving the possibility of the individual assuming her/himself as a being-to-death; Manifestation of the care and concern, which comprehends the moment of caring as a meaning in the existence; and Dasein in the hospital setting, which comprehends the being inserted in a world with a narrow limit between life and death. Conclusion: The understanding of the phenomenon experienced by these family members allowed to apprehend the dimension of the suffering regarding the condition of being-in-the-world providing care in the death process. This study points to the relevance of the death theme in the education of health professionals and the need for reflecting on this issue so as to develop a compatible care to the situation experienced by families in face of this terminal situation.
\end{abstract}

Keywords: Attitude to Death. Family. Terminally III. 


\section{SUMÁRIO}

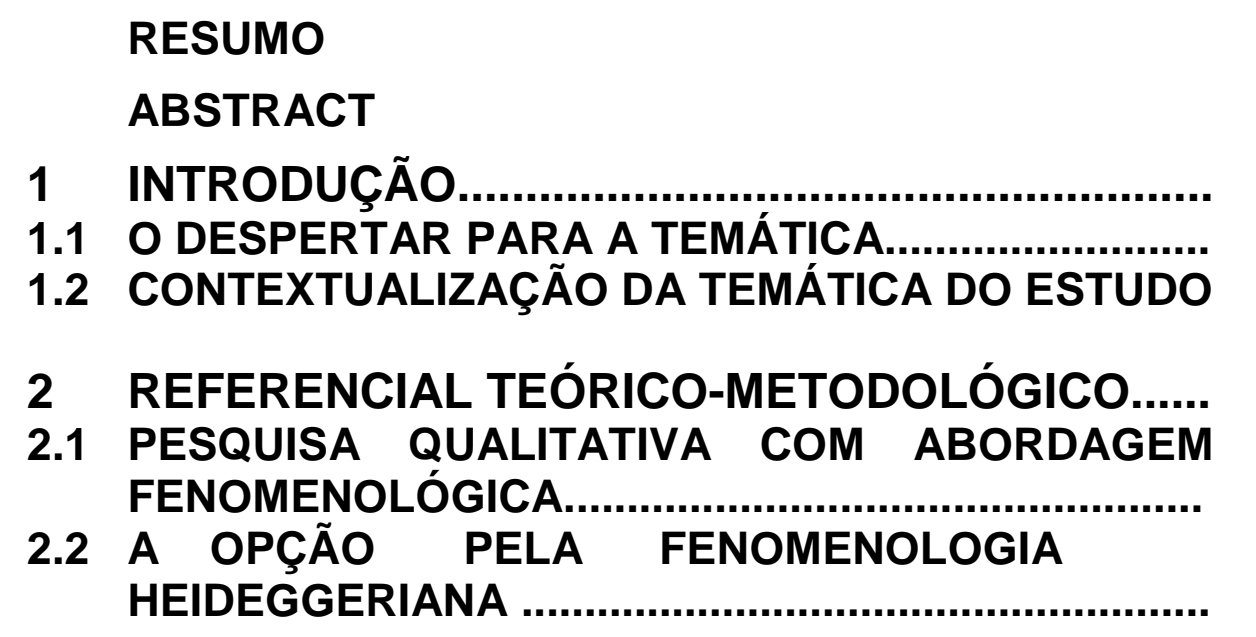

11

12

15

32

33

3 PERCORRENDO O CAMINHO METODOLÓGICO 53

3.1 CENÁRIO E REGIÃO DE INQUÉRITO....................... 54

3.2 SUJEITOS DO ESTUDO............................................ 55

3.3 PRINCÍPIOS ÉTICOS.............................................. 56

3.4 OBTENDO OS DISCURSOS................................. 57

3.5 CAMINHANDO PARA O MOMENTO DA ANÁLISE DOS DISCURSOS................................................ 57

4 TECENDO OS RESULTADOS............................ 59

4.1 APRESENTANDO OS FAMILIARES........................ 60

4.2 CONSTRUINDO OS RESULTADOS

RELACIONADOS AO FAMILIAR........................... 64

5 CONSIDERAÇÕES FINAIS....................................107

REFERÊNCIAS...................................................107

APÊNDICES...................................................... 122

APÊNDICE A- Termo de Consentimento Livre e Esclarecido.........123

ANEXOS......................................................................... 125

ANEXO A - Parecer do Comitê de Ética em Pesquisa da Escola

de Enfermagem da Universidade de São Paulo........................... 126 
1 INTRODUÇÃO 


\section{INTRODUÇÃO}

\subsection{O DESPERTAR PARA A TEMÁTICA}

Minhas inquietações diante da vivência dos familiares deramse no decorrer da minha vida profissional, quando iniciei minhas atividades na Unidade de Terapia Intensiva (UTI). Na ocasião, optei por realizar um curso de especialização em Terapia Intensiva, que me oportunizou um conhecimento teórico-prático relativo ao cuidado com o paciente crítico e a oportunidade de elaborar trabalhos científicos. Entre eles, alguns eram referentes à assistência de enfermagem aos familiares dos pacientes internados na UTI.

Acreditando que a internação na UTI pode afetar diretamente a dinâmica da família do paciente internado e gerar emoções variadas nos seus membros, surgiu meu interesse pela perspectiva subjetiva do familiar a respeito da experiência de ter um paciente internado nesse setor, gerador de tantos sentimentos conflitantes.

Baseando-me nessas considerações, entendi que seria necessário buscar subsídios para melhor qualificar os cuidados de enfermagem prestados aos familiares. Ingressei no programa de pós-graduação, a nível de mestrado. Optei por realizar um estudo fenomenológico, em uma UTI, para responder ao questionamento de como é para esses familiares a vivência de ter um membro da família internado na UTI (COMASSETTO; ENDERS, 2009).

Ao elucidar o fenômeno vivido por esses familiares, surgiu uma nova inquietação, visto que a categoria que obteve maior ênfase e chamou mais a minha atenção, neste estudo, foi a do medo da morte sentido pelo familiar do paciente internado.

O fenômeno desvelado nos depoimentos dos familiares apresentava uma intenção de negação da morte como um fato a ser consumado em casos de pacientes em que não havia mais perspectiva de melhora, percebia-se inclusive por expressões 
usadas como "indo embora" e "perder o familiar". Diante da possibilidade concreta da morte, os sentimentos de medo, de angústia, de desespero e de tristeza estavam sempre presentes, assim como certa desesperança por sentirem-se impotentes perante a possibilidade da perda do seu familiar.

Nessa época, já existia em mim uma estabilidade no enfrentamento da morte, enquanto profissional que convive com a perda do ser humano, porém faltava aporte para subsidiar o planejamento de uma assistência específica para os familiares que passam por essa experiência.

Logo após o término do mestrado, afastei-me das atividades de enfermeira assistencial e iniciei minhas atividades profissionais na docência com a enfermagem.

Ao desempenhar atividades assistenciais de enfermagem, com alunos de graduação e pós-graduação, nos setores de internação hospitalar de pacientes adultos de um hospital universitário, embora em um contexto diferente do vivido anteriormente, deparei-me novamente com a situação dos familiares de pacientes internados e que viviam supostamente as mesmas angústias que eu já havia presenciado anteriormente, relativas à possibilidade de perda de um familiar.

Tais observações conduziram-me a repensar, do mesmo modo, o meu assistir aos familiares nessa situação existencial de vivenciar a perda. A partir dessa interação, enquanto profissional docente-assistencial, emergiu no meu cotidiano o meu sendo-nomundo-com-o-familiar, que vem ao encontro do mundo-vida dentro de um hospital onde o familiar vivencia a perda diferentemente, tendo seu sentido próprio, seu modo de ser, em seu sendo-nomundo.

Portanto, nessa trajetória, enquanto enfermeira inserida na docência, volto minha atenção e intenção de responder, neste estudo, à seguinte questão norteadora: Como é a experiência vivida 
pelo familiar do paciente adulto, em fase terminal de vida, que enfrenta o processo de morrer no mundo do hospital?

Infiro-me, no parágrafo anterior, que compreenderei a vivência do familiar do paciente em fase terminal de vida. Mas, afinal, o que se entende por paciente em fase terminal de vida? Dentre as diversas definições, vou ater-me à definição de Gutierrez (2001, p.92), por considerar a resposta mais sensata a esta pergunta. $O$ autor afirma que o paciente pode ser identificado como terminal, quando todas as possibilidades de tratamento em busca das condições de saúde foram esgotadas, de tal forma que a morte iminente parece inevitável e previsível. Daí, torna-se "irrecuperável" e "caminha para a morte, sem que se consiga reverter este caminhar".

Diante do exposto, a minha proposta justifica-se pelo fato de que, estando de posse da compreensão da experiência desses familiares que vivenciam o processo de perda do seu paciente, obtenho respostas concretas em relação às suas atitudes $e$ comportamentos, a fim de conhecer suas reais necessidades de cuidado.

Assim como obtenho conhecimentos para uma melhor compreensão por parte dos enfermeiros e demais profissionais da equipe de saúde frente às decisões terapêuticas, compatíveis com as suas necessidades, visando ao bem-estar físico, mental e social, tanto do familiar em questão, quanto do paciente inserido nesse contexto. Além disso, os resultados desse estudo podem contribuir com as ações e com programas propostos pelas políticas de saúde, com a finalidade de oportunizar saúde e bem-estar ao cidadão brasileiro.

Para obter essa compreensão, é necessário imergir profundamente na vivência desses familiares, permeada por sentimentos profundos, com um reflexo cultural importante, que fundamenta o comportamento, enquanto seres humanos fragilizados 
que buscam a superação do sofrimento diante das adversidades dessa experiência.

Baseada nessas considerações, com o propósito de desvelar esse fenômeno pela ótica de quem vivencia essa experiência, optei em realizar este estudo, com o objetivo de compreender a experiência do familiar de pacientes em fase terminal de vida, que enfrentam o processo de morrer no mundo do hospital.

\subsection{CONTEXTUALIZAÇÃO DA TEMÁTICA DO ESTUDO}

Por acreditar que vivenciar o processo de morrer é uma experiência permeada por muitos conceitos, considero importante salientar que a morte vai além do conceito biológico referente à cessação das atividades biológicas necessárias à caracterização e manutenção da vida, e esteja vinculada a considerações significativas para a nossa existência, no que diz respeito ao desenvolvimento social, cultural e histórico. Portanto farei a seguir uma explanação sobre como a morte e o morrer tem habitado a existência do homem.

De posse dessa elucidação, prossigo a contextualização da temática com reflexões acerca do processo de morrer no cenário hospitalar e sobre as interfaces do cuidar do familiar diante da morte e do morrer.

\section{Falando sobre a morte e o morrer}

O nascer e o morrer são fenômenos naturais, diante dos quais todos os homens igualam-se, independentemente do seu status social, nacionalidade, cor da pele, ou crença religiosa. Entretanto o estar diante da morte é um fator gerador de angústia, vinculado à própria existência do homem (SANTOS, 2009). Assim sendo, as atitudes construídas diante da morte decorrem da consciência humana de sua finitude. 
Desse modo, a morte e o processo de morrer vêm modificando-se durante séculos, de acordo com as influências culturais e as necessidades dos homens em relação aos papéis sociais que a eles se incorporam (SALMAZO-SILVA et al., 2012). É manifesto que a sociedade passou por transformações históricas concernentes às atitudes diante da morte, sendo importante e necessário considerá-las, desde a morte vivenciada com preparo e tranquilidade, até o momento em que se transformou em temor e aflição, como a vivida nos dias atuais (SOUZA; BOEMER, 2005).

De tal modo, a morte é vista como um desafio para o homem, desde os tempos mais remotos da nossa existência, sendo manifestada de acordo com a influência sociocultural e histórica das diferentes civilizações (AGRA; ALBUQUERQUE, 2008). Assim como as dificuldades, as necessidades inerentes ao lidar com a morte atualmente também foram adquiridas por meio dessa herança cultural (ALENCAR; LACERDA; CENTA, 2005).

Com a intenção de uma aproximação e melhor compreensão histórica sobre a morte, tomo como referencial as pesquisas de Ariès (2003), historiador francês que, baseado em seus estudos sobre as culturas cristãs ocidentais da Idade Média, elaborou, entre outros, dois livros intitulados "O homem diante da morte" e "História da morte no ocidente".

Segundo Ariès (2003), havia, no início da Idade Média, uma familiaridade com a morte, denominada de "Morte domada", vista com naturalidade e possuía uma atitude familiar e próxima, como também atenuada e indiferente. Era a morte precedida de um aviso dado por signos naturais, ou por uma convicção íntima. As mortes ocorriam nas guerras, ou por doenças, permitindo ao homem conhecer a trajetória da sua morte e tomar tranquilamente suas providências.

O chamado Cerimonial do Moribundo envolvia atos, inicialmente com o lamento da vida, envolvendo uma evocação nostálgica, porém discreta, dos seres e coisas amadas. $O$ segundo 
ato compreendia o perdão dos companheiros. O cerimonial era finalizado com o terceiro ato que compreendia a absolvição sacramental.

A morte era uma cerimônia pública, e o cerimonial era organizado pelo próprio moribundo, quando todos podiam participar da despedida: parentes, amigos, vizinhos e crianças. Os ritos da morte eram aceitos e cumpridos com manifestação de tristeza e dor, porém sem caráter dramático, ou emoção excessiva. O maior temor era ter uma morte repentina, sem receber as homenagens.

Outro aspecto importante dessa antiga familiaridade com a morte era o temor da coexistência dos vivos com os mortos, tanto com o físico, pela decomposição dos corpos, como pelo aspecto psíquico. Assim, para garantir que os mortos não voltassem para perturbar os vivos, os rituais funerários eram praticados.

Entretanto, com o culto aos mártires, uma nova visão surgiu, tendo como objetivo a proteção das cidades: seus restos mortais eram enterrados nos locais onde foram construídas as igrejas. Posteriormente, para as pessoas com maior prestígio era garantido um enterro dos seus corpos nas igrejas e basílicas, obtendo maior valorização os lugares mais próximos aos altares. Aos mais pobres era destinado o pátio da igreja, local onde ficava o cemitério, uma área pública que servia como ponto de encontros e comércio.

Entre os séculos XI e XII, ocorreram mudanças sutis na solenidade do ritual da morte. É percebido um caráter mais dramático e grande carga de emoção nas classes mais instruídas. No período compreendido entre os séculos XII e XV, passa a haver uma maior conscientização quanto à própria morte.

Pequenas mudanças aconteceram, trazendo um aspecto pessoal na relação do homem com a morte, seu medo maior relacionava-se com a pós-morte. $O$ julgamento pessoal ganha ênfase com as crenças populares de não se ser salvo no juízo final, por cair em tentação, representada pelo apego às "coisas terrestres", como família e objetos materiais. 
Como forma de negar a morte, os corpos eram escondidos em caixões, e o embalsamento continuava sendo usado, a fim de manter a imagem do morto. Gradativamente, as sepulturas coletivas nas igrejas vão sendo substituídas por túmulos individuais.

No século XVI, a morte passa a ser vista como uma separação inaceitável. A morte do outro toma importância e assume um caráter dramático e complexo.

A partir do século XVIII, há uma ruptura com o antigo conceito de morte, e o homem da sociedade ocidental passa a dar um novo sentido para a morte, valorizando-se mais a do outro do que a sua própria, e a responsabilidade pelo cerimonial passa a ser da família e não mais do doente.

No século XIX, uma intolerância à separação é percebida, o sofrimento é apresentado em forma de uma dor exacerbada pelos familiares e amigos diante da morte, por ser sentida como uma ruptura, uma perda. Destaca-se um novo ritual com a visitação frequente ao túmulo do morto e o culto da lembrança. A sociedade cultua seus heróis, e os túmulos transformam-se em monumentos.

No século $X X$, surge uma nova forma de ver a morte, que se tornou escondida, ameaçadora e selvagem, que Ariès (2003) denomina de "morte interdita". Com esse novo conceito, o homem doente passa a ser poupado do sofrimento que poderia ter, ao receber informações referentes ao seu estado de saúde e consequente proximidade da sua própria morte. O lugar de morrer é deslocado para os hospitais, tidos, então, como locais onde se prestam os cuidados específicos que não são possíveis em casa, conhecidos como centros para pacientes terminais. Nesse contexto, a morte não terá os elementos dramáticos da morte ocorrida no domicílio entre os familiares.

Desde então, apesar de o tema da morte ter sido suprimido, contraditoriamente, ele esteve e permanece muito presente no início do século XXI. A morte apresenta-se simultaneamente presente, 
agressiva e sem limites. Apesar de tão próxima, sobre ela prevalece um acordo tácito para não se falar a respeito (KOVÁCS, 2005).

Portanto, convivendo com a morte interdita, essa morte escancarada define-se como sendo a morte que "invade, ocupa espaço, penetra na vida das pessoas a qualquer hora". Pode ser exemplificada como a morte violenta, os acidentes e os homicídios e a morte veiculada pela mídia. Essa morte expõe as pessoas, devido ao contexto que circunda, a proteção e o controle das consequências não são permitidos, por despertarem sentimentos variados sem tempo suficiente para reflexão e elaboração da morte (KOVÁCS, 2003, p. 140).

A morte explícita, ou velada, paira sobre a existência da vida humana. A esse respeito, Pessoa (2012) afirma que, ao considerá-la como realidade, independente dos aspectos socioculturais. A morte constituirá um fator gerador de medo que suscitará sentimentos de angústia, ansiedade, com diferentes dimensões e reações. Consoante a essa afirmação, Silva (2012) defende que o homem ocupa-se em não refletir, discutir ou aceitar sua finitude, pois, para ele, ser de natureza mortal é complexo e permeado de sentimentos de incompletude.

A seguir, passo a apresentar algumas considerações no que tange aos aspectos evidenciados sobre como é vivenciada a morte no cenário hospitalar pelos envolvidos nesse processo.

\section{Falando sobre o processo de morrer no cenário hospitalar}

Com o progresso da tecnologia acerca da área médica, novas questões sobre a vida e a morte são manifestadas atualmente. As instituições de saúde têm sido designadas como o lugar onde se deve estar para morrer. Nesse local, a morte passa a ser interferida e, por vezes, decidida pela equipe que acompanha o paciente nos cuidados em final de vida (KOVÁCS, 2008), apesar de o predomínio dos tratamentos intensivos e algumas intervenções nos pacientes 
que estão na fase terminal de vida possam ser percebidas como inadequados (VICTOR et al., 2003) e considerados invasivos e agressivos (WILLARD; LUKER, 2006).

Assim, a morte que foi mantida por muitos anos presente no cotidiano dos homens de maneira natural, atualmente se apresenta como um obstáculo a ser superado, ou, ao menos, adiado. Pessini (2009) sugere que essa característica humana da busca pelo domínio sobre a vida e sobre a morte passa a interferir, de forma intensa e crescente, na ciência médica, baseada em ações que contribuíram com o sucesso até então conquistado, porém essas ações geram situações complexas que se refletem nos questionamentos éticos acerca da morte e do morrer no contexto hospitalar.

A própria morte e até mesmo a dor, muitas vezes, escapam do controle da ciência médica e passam a ser vistas como fracasso. De tal modo que, diante da luta, para garantir o máximo prolongamento da vida, fica notório que a quantidade de vida sobrepõe-se à qualidade da vida a ser prolongada. Em decorrência disso, constitui-se a ausência do cuidado pela boa morte cultivada, assim como a aversão à "eutanásia provocada como derrota diante do inimigo, chamado morte" (PESSINI, 2009, p.40).

Essa percepção é favorecida pelo modelo biologicista que mantém a atenção voltada para a patologia, o órgão doente e os procedimentos técnicos. Como consequência desse paradigma, ocorre a desvalorização dos sentimentos e temores do paciente e dos seus familiares, influenciando, de forma direta, na maneira como vivenciam a situação da saúde-doença (SOUZA, 2012). Que, segundo Kovács (2008), os familiares passam a ser mantidos alheios aos cuidados no tratamento dos seu familiar internado.

Santa Rosa e Fontoura (2013) justificam que os profissionais não foram preparados para promover essa assistência ao paciente em final de vida, porque esse assunto assume menor importância 
pelas organizações de saúde, pois, diante da doença, o hospital é preparado como local onde se busca a esperança de sair curado.

Portanto, no ambiente hospitalar, a morte apresenta-se velada, um fenômeno inevitável e assustador, e os profissionais possuem dificuldades para sua aceitação e compreensão por consequência da falta de preparo.

Porém a morte, por fazer parte do ciclo vital, acontecerá e não poderá ser negligenciada, exigindo que os profissionais da saúde estejam preparados para enfrentá-la e aptos a disponibilizar suporte aos familiares que vivenciam esse momento complexo, pois haverá um grande impacto da finitude no círculo familiar, com várias consequências, passando a existir uma necessidade real de apoio profissional para que os familiares possam enfrentar as dificuldades em vivenciar essa experiência e elaborar o luto (LISBOA; CREPALDI, 2003).

Kovács (2009) considera que enquanto o termo morte for envolto em silêncio pelos profissionais, permanecerá gerando um penar, derivado de um sentimento de fracasso profissional. Acrescenta, ainda, que, enquanto a busca pelo prolongamento da vida promove maior tempo de convívio entre o paciente, seus familiares e a equipe que presta os cuidados ao paciente em sua finitude, consequentemente aumentará a propensão ao alto nível de estresse e ameaça de um colapso.

No que se refere ao estresse vivido diante da finitude pelos profissionais, Ritter, Stumm e Kircher (2009) acrescentam que, assim como os que ainda estão em formação a abordagem sobre a finitude humana, é de vital importância para promover a compreensão dos sentimentos, temores e anseios que permeiam essa experiência, visto que o estresse negativo, resultante dessa experiência pode favorecer ao adoecimento manifestado com a exaustão emocional, despersonalização e falta de comprometimento com o trabalho. 
Rosenbaum, Lobas e Ferguson (2005) e Bitencourt et al. (2007) corroboram que há uma fragilidade no ensino dos profissionais de saúde, no que diz respeito à tanatologia de um modo geral, sendo negligenciados os aspectos referentes às relações interpessoais, ao estudo da morte e do morrer, o que, consequentemente, acarreta um déficit no aprendizado das habilidades de comunicação. $O$ que se vê com mais frequência é o desenvolvimento de temas direcionados a aspectos técnicos, procedimentos e intervenções. Levy e McBride (2006), com o intuito de melhorar a qualidade de vida no processo de morrer, salientam a importância de uma apreciação da educação para a equipe multiprofissional.

Assim como faz-se necessário que as instituições formadoras reflitam sobre a possibilidade do impacto causado na vida desses profissionais e promovam um trabalho com a intenção de capacitálos, a fim de ir além do domínio técnico, disponibilizando oportunidades de reflexão acerca da morte, permitindo que aprendam a desenvolver sentimentos, como a empatia, a congruência, o acolhimento e o diálogo, habilidades fundamentais para o cuidado no processo de morrer para os pacientes e seus familiares (BORGES; MENDES, 2012).

Para atingir esse propósito, Main (2000) acrescenta como princípio fundamental um preparo dos profissionais respaldado primeiramente na compreensão dos seus próprios sentimentos referentes à morte e ao morrer, sendo necessário desenvolver tais habilidades, para saber lidar com situações difíceis, assim como ter uma maior compreensão das necessidades psicológicas do paciente em processo de morrer e do seu familiar, pois poderão revelar desconforto ao lidar com o paciente e com os familiares nesse processo, caso não estejam pessoalmente conscientes da questão da morte e do morrer bem elaborado. 
A seguir, passo a apresentar algumas considerações a respeito do cuidado com a família que vivencia a finitude humana no seu núcleo familiar, quando inserida em um contexto hospitalar.

\section{Falando sobre as interfaces do cuidar do familiar diante da morte e do morrer}

Família é uma unidade dinâmica onde as pessoas convivem com direitos e responsabilidades em um determinado ambiente, influenciados por uma cultura, durante um determinado tempo, unidos por laços afetivos, de consanguinidade, afetividade ou interesses (LACERDA, OLINISKI, 2004). As autoras Wright e Leahey (2002, p.68) propõem que "família é quem os seus membros dizem que são", sendo aplicável a qualquer tipo de família. Por serem consideradas mais pertinentes ao tema, estas definições serão as adotadas neste estudo.

Ciente da importância que a família possui no contexto do cuidado com o paciente, em todos os momentos de um tratamento $\mathrm{e}$ em busca de um atendimento mais humanizado, a prática da enfermagem tem ampliado, cada vez mais, o centro de atenção, e um novo modelo assistencial tem sido delineado, sendo notório que a enfermagem, além do paciente, começa a incluir a família na promoção e na manutenção da saúde.

A família passa a ser objeto de pesquisa e centro de atenção para vários pesquisadores que se propõem a buscar uma instrumentalização, a fim de que a enfermagem possa ser exercida de forma integral. Wright e Leahey (2002) fazem excelente contribuição, apresentando em sua obra Nurses and Families uma abrangência na avaliação e intervenção centrada na família. Outros trabalhos publicados, como os de Lynn-McHale; Deatrick (2006) e Wright (2008), discutem a respeito do cuidado com a família. Assim como, no Brasil, autores também dedicam suas pesquisas à família 
(ÂNGELO, 1997, 2009; BOUSSO, 2006; COMASSETTO; ENDERS, 2009; KOMESSU, 2009) entre outros.

No que concerne especificamente à atenção aos familiares dos pacientes hospitalizados em processo de morrer, a enfermagem poderá estar acompanhando-os na elaboração das questões relativas a essa experiência, embasada em autores que abordam essa temática nas suas pesquisas, buscando compreender experiências, prioridades e percepções em relação à qualidade de cuidado (DOWNEY et al., 2009; FRIDH; FORSBERG; BERGBOM, 2007; HAWKER et al., 2006; HEBERT et al., 2009; HEYLAND et al., 2006; KING ; BELL; THOMAS, 2004; LIMA; ROSA, 2008; LINS, 2007; MENDES; LUSTOSA; ANDRADE, 2009; PEREIRA; DIAS, 2007; SPICHIGER, 2008; STARKS et al., 2007; TENO et al., 2004; WILLARD; LUKER, 2006).

Porém, embora autores dediquem-se a discutir esse tema, ainda existe uma lacuna na produção de um embasamento teórico, sendo real a necessidade de melhor instrumentalizar os profissionais de saúde, para que possam realizar intervenções adequadas a esses familiares, visando a atender às suas necessidades (BELLO et al., 2009; EDNAMARE; SUDIGURSKY, 2008; KREITZSCHITZ; MACPHERSON, 2003; MARENGO; FLÁVIO; SILVA, 2009; ZAYAS, 2006).

É justamente essa lacuna na produção referente ao tema que chama a atenção de autores, que apontam como fator determinante sobre a falta de preparo dos profissionais para lidar com situações que envolvem a morte e o morrer no contexto em que desenvolvem seu trabalho diário (BECKSTRAN; CALLISTER; KIRCHHOFF, 2006; BRYSIEWICZ, 2008; GUINART, 2006; MAIN, 2002; KIRCHHOFF et al., 2002).

Assim, ao realizar a revisão para elaborar este tópico sobre as interfaces do cuidar do familiar diante da morte e do morrer quando inserida em um contexto hospitalar, foi notório que grande parte dos estudos que compuseram a minha busca evidenciaram, muitas 
vezes, a existência de falta de preparo entre os profissionais da saúde, influenciando a assistência oferecida aos pacientes e aos familiares.

Essa informação é coerente com o resultado da busca realizada para discutir o tópico anterior, quando falo sobre o processo de morrer no cenário hospitalar e obtenho a elucidação de que a morte é velada desde a formação acadêmica, permanecendo durante o desempenho das atividades assistenciais.

Passo a seguir a conversar com alguns autores sobre considerações que se mostraram pertinentes.

Segundo Trincaus e Côrrea (2007), muitos familiares somente conseguem adquirir uma real consciência da possibilidade da finitude, quando se deparam com uma situação crítica, que os leva a refletir sobre o sentido existencial da vida, configurando-se como um momento bastante assustador nas suas vidas.

A real possibilidade da finitude de um membro familiar é um momento capaz de desestruturar uma família, sendo comum a sensação de perda de controle sobre a vida, que pode ser extremamente debilitante e forçá-los-á a enfrentar a destruição do mito familiar de que as doenças fatais somente acontecem com os outros (WALSH; McGOLDRICK, 1998). Consequentemente, quando uma família vê-se diante de um prognóstico que gera tamanho impacto sobre o núcleo familiar, a vida tida como normal é destruída (OLIVEIRA et al., 2005).

Assim, a possibilidade concreta da morte causará um vazio existencial nos familiares, que são tomados pelo pessimismo, frustração, desorientação, podendo levar a uma perda de sentido para continuarem suas vidas (LIMA; ROSA, 2008), pois há um comprometimento da qualidade de vida, proveniente de um profundo sofrimento gerado pelo processo do morrer, que se caracteriza por sentimentos de angústia, vulnerabilidade, descontrole emocional e ameaça à sua integridade e autonomia (PESSINI, 2004). 
Acrescentam-se a esses sentimentos solidão existencial, tristeza, desapontamento, raiva, ressentimento, culpa, exaustão, desespero e ansiedade pela futura separação (WALSH; McGOLDRICK, 1998). Essa ansiedade pode também ser sentida pelos familiares diante da dificuldade em aguardar o momento da morte do seu ente querido (LISBOA; CREPALDI, 2003).

Pereira e Dias (2007) acrescentam ainda que o familiar pode sentir um sofrimento intenso, por haver alternância de momentos de culpa, pelo desejo de morte do paciente que trará fim ao sofrimento, de fé e de esperança diante da expectativa de uma melhora.

Essa fé e essa esperança, para Lima e Rosa (2008), podem ser sentidas com otimismo e percebido como possibilidade de responder às questões da vida de modo positivo pelo meio espiritual. Nessa situação, Bertoldo e Girardon-Perlini (2007) acrescentam que haverá um compartilhar de responsabilidades e emoções vividas, de acordo com os significados que a experiência tem para cada membro da família em particular.

Aliada à adaptação da ameaça da perda imposta em suas vidas, incide a inserção do contexto hospitalar no cotidiano desses familiares. Estudos ponderam sobre a existência de um sentimento de insatisfação durante o período de internamento do familiar em processo de finitude por parte dos familiares, sendo apontada como fator predominante a deficiente comunicação estabelecida com os profissionais de saúde (BRYSIEWICZ, 2008; HEYLAND et al., 2006; GIGLIO, 2005; WIEGAND, 2006).

Para Soares (2007), esse familiar apresentará necessidades específicas para o momento vivido, como permanecer próximo ao doente e estar inserido no contexto vivido, compreendendo tudo o que está acontecendo, tendo a certeza de que o sofrimento e a dor estão sendo controlados, e que o tratamento realizado é o apropriado. Acrescenta, ainda, que a família deseja expressar seus sentimentos angustiantes, ser consolada e encontrar um significado para a morte do seu familiar. 
Porém, para Starks et al. (2007), os profissionais de saúde não consideram o familiar como sujeito presente e envolvido no processo da morte, consequentemente não oferecem auxílio aos membros da família no processo de reconhecimento e aceitação da perda do seu ente querido, assim esses familiares não recebem apoio para a assimilação do papel de familiar de um paciente em finitude. Inaba, Silva e Telles (2005) reconhecem que é importante que os profissionais conheçam os familiares, observando seus gestos, falas, comportamento, conceitos, limitações e reações.

Segundo Steinhauser et al. (2000), cuidados de qualidade devem ser oferecidos no final da vida, individualizados e alcançados através de um processo de tomada de decisão compartilhada e uma comunicação clara, proporcionando um reconhecimento das preferências e das necessidades dos pacientes e sua família.

No que concerne à manutenção de uma boa relação com os familiares, compartilhando das informações sobre o paciente, Main (2002) considera importante manter a família informada sobre a evolução clínica e a valorização das necessidades dos familiares, o que acarretará um efeito positivo sobre a capacidade dos familiares em lidar com a perda.

Para tanto, Heyland et al. (2006) acrescentam que os familiares e os pacientes consideram necessário reforçar e melhorar essas relações, através de uma boa comunicação com o médico assistente e a equipe de saúde, construindo relações de confiança, satisfazendo as necessidades de informações, tomadas de decisão e definição de papéis. Assim, será obtida uma melhor qualidade de vida durante o processo de morrer. Rabow, Hauser e Adams (2004) acrescentam que os médicos e a equipe de saúde, quando estabelecem uma boa comunicação e oferecem suporte a esses familiares, o beneficiamento será mútuo.

A comunicação é uma forma de gerenciar o momento vivido pelos familiares, considerando que poucos eventos são tão incertos quanto a morte e o morrer. As pessoas avaliam a morte como uma 
ameaça e usam estratégias de enfrentamento na tentativa de conduzir melhor essa ameaça, que pode ser amenizada com um efetivo relacionamento da equipe de saúde com os familiares (HEBERT et al., 2009).

Em concordância, Kirchhoff et al. (2002) citam a comunicação como a melhor forma de contribuir no suporte aos familiares com sentimentos de incerteza e de inconformidade diante de agravamento no prognóstico, de decisões difíceis que a família toma, inerentes ao tratamento, assim como afirmam que ela auxilia no sofrimento que permeia essa experiência diante de um processo de morrer de um familiar.

Rabow, Hauser e Adams (2004) afirmam que a experiência de cuidar do seu familiar em processo de morrer pode gerar sentimentos de realização profunda, ou um trauma significativo. Nesse processo, a comunicação eficaz é tida como facilitadora para o reconhecimento das responsabilidades do familiar cuidador, no auxilio para a tomada de decisão, no apoio ao atendimento domiciliar, no suporte às emoções e no reconhecimento do luto. Porém, caso seja instalada uma difícil comunicação entre equipe e familiares, Zayas (2006) afirma que um sentimento de ansiedade será gerado.

Outra perspectiva que aponta que a comunicação merece discussão é a referente à relação da família com o seu familiar em processo de morrer. Lisboa e Crepaldi (2003) argumentam que se houver estímulo, a comunicação entre os familiares, nesse momento, pode ter um efeito muito saudável para todos os envolvidos, principalmente nos casos em que há uma relação de discórdia e discussões, sendo importante o preparo emocional dos familiares para aceitarem a morte e prepararem-se para o desapego, e acrescentam que diversas vezes faz-se necessário um consentimento ou estímulo para facilitar a proximidade entre eles, para que haja essa conversa. 
Embora o ser humano tenha como certa a morte em sua existência, os familiares, na maioria das vezes, não estão em condições de abordar diretamente sobre a possibilidade da presença morte diante do seu paciente, como situação concreta (TRINCAUS; CORRÊA, 2007).

Nessa situação, torna-se comum uma aliança entre a família e os profissionais, pactuando na restrição da informação (QUINTANA et al., 2006). Por outro lado, poderá ser uma experiência complexa.

Wenrich et al. (2001) consideram necessário que o médicoassistente avalie sobre o melhor momento para as informações referentes ao prognóstico da doença sejam compartilhadas com o paciente, tendo como base os diálogos mantidos com o este. Segundo Willard e Luker (2006), o paciente, quando vivencia sua finitude, espera participar das decisões que lhes dizem respeito.

$\mathrm{Na}$ inserção do paciente nesse processo, é recomendado que as emoções possam ser expressas, e as dúvidas e medos possam ser definidos, facilitando a percepção do paciente de que não está sozinho e que continua sendo importante para sua família.

Para tanto, é fundamental que sua opinião seja valorizada pelo familiar, que deve avaliar e explorar o processo de morrer de um modo apropriado e sensível (GOMES, 2010). Alencar, Lacerda e Centa (2005) questionam sobre a liberação da presença dos familiares junto aos pacientes que ocorrem mais frequentemente somente no estágio final de vida, justamente quando o paciente está em estágio de inconsciência e desorientação ou sedado. Tal atitude possibilita apenas aos familiares o ritual de despedida, e não aos pacientes. Segundo Gomes (2010), a família pode romper o silêncio, com apoio profissional, evitando a omissão de uma morte que se aproxima, assim como possibilitar a livre expressão de sentimentos.

Merighi e Carvalho (2006) afirmam que, nos últimos tempos, a valorização da qualidade dos cuidados em final de vida tomou proporções amplas, uma vez que se têm ponderado soluções concernentes à busca de condições adequadas que podem 
proporcionar excelência nos cuidados e dignidade essencial no final de vida. A qualidade de vida possui grande valor para processo de morrer com dignidade, uma vez que a vida e a morte são vistas de uma forma especial, quando analisadas pelas pessoas que presenciam a perda da vida gradativamente e a proximidade da finitude inevitável. O sentimento de impotência diante da doença, a sensação de incapacidade, a constante expectativa de morte, a descrença em relação às medidas curativas estabelecem frequentemente uma estagnação diante da realidade dos limites dos tratamentos na busca da cura e das demandas da preservação da qualidade de suas vidas.

Assim, Lisboa e Crepaldi (2003) ressaltam a importância da orientação profissional, estimulando à paciência e à força para esperar pela morte, aceitá-la e deixar seu ente querido partir, mantendo estabilidade emocional, pois trata-se de um momento solene, apesar da simplicidade em que pode acontecer.

É essencial que os familiares consigam exercitar o desapego. Deixá-lo ir antes da morte de um ente querido envolverá uma mudança de pensamento, em que haverá um reconhecimento da perda iminente sem impedir a sua natural progressão. Assim, uma ligação emocional e o reconhecimento de que todo o possível pelo seu familiar foi realizado são seguidos de uma morte pacífica e natural reconhecimento da mudança (LOWEY, 2008).

O ritual de despedida realizado com o paciente ainda em vida, segundo Lisboa e Crepaldi (2003), ajudará na aceitação da morte e na elaboração do luto. Para Bertoldo e Girardon-Perlini (2007), dependerá da forma como sentimentos distintos tenham sido experienciados, assim como da tranquilidade por terem desempenhado o seu papel, de reconhecimento pelos ensinamentos, de proteção e aceitação diante da perda.

Essas considerações fortalecem a relevância do tema e a necessidade de compreender-se a vivência do familiar de pacientes 
adultos, em fase terminal de vida, que enfrentam o processo de morrer no ambiente hospitalar.

A seguir, apresento a escolha do método de investigação e o referencial filosófico que norteiam a trajetória do estudo. 
2 REFERENCIAL TEÓRICO-METODOLÓGICO 


\section{REFERENCIAL TEÓRICO-METODOLÓGICO}

\subsection{PESQUISA QUALITATIVA COM ABORDAGEM FENOMENOLÓGICA}

Para a realização deste estudo, tendo em vista a natureza do objeto de investigação que enfoca o fenômeno vivido pelo familiar de pacientes em fase terminal de vida, que enfrentam o processo de morrer no mundo do hospital, considero o método qualitativo pertinente. Essa categoria de pesquisa direciona a busca do específico, a fim de compreender o fenômeno na sua essência.

A pesquisa qualitativa surgiu no século XIX, sob um contexto de ideias que visualizavam a investigação por meio da compreensão do próprio ser, denotando uma interpretação de sentidos e significações e captando suas interligações. Tal método, que era até então designado à filosofia, passa a ser utilizado por antropólogos, sociólogos e educadores e veio posteriormente a ser utilizado amplamente por profissionais da área da saúde, a fim de ampliar a compreensão sobre o ser e aplicar esse conhecimento nas práticas de assistência à saúde (TURATO, 2003).

O método de pesquisa qualitativa, segundo Minayo (2006), tem a capacidade de incorporar a questão do significado e da intencionalidade no mundo das ações e relações humanas, valorizando a realidade que não pode ser quantificada. Enquanto que a pesquisa quantitativa trabalha com fatos, entendidos pelo positivismo como aquilo que pode ser rigorosamente estudado enquanto objeto da ciência e controlado após ter sido definido.

Pesquisadores utilizam a pesquisa qualitativa, quando existe uma lacuna no conhecimento, ou quando pouco é sabido a respeito de um determinado fenômeno, experiência ou conceito (POPE; MAYS, 2009). Para realizar uma pesquisa qualitativa, o foco de atenção estará centrado nos aspectos específicos, individuais e 
característicos, buscando compreender e não explicar o fenômeno estudado (MARTINS; BICUDO, 2005).

Esses fenômenos são compreendidos como aquilo que se mostra em si mesmo situando-se. Somente há fenômeno psicológico, enquanto houver um sujeito no qual ele se situa. Assim, busca introduzir um rigor aos fenômenos incapazes de serem quantificados, como angústia, ansiedade, medo, tristeza, entre outros (MARTINS; BICUDO, 2005).

Esse método de pesquisa é realizado no ambiente natural onde o ser habita (POPE; MAYS, 2009). O ambiente contrasta fortemente com o cenário clínico e/ou laboratório usado na pesquisa quantitativa, que, propositalmente, exerce maior controle sobre o estudo e as variáveis (VISHNEVSKY; BEANLANDS, 2004).

Por ser indutiva, a pesquisa inicia-se com objetivos exploratórios mais amplos que fornecem foco para o estudo, sem esgotar prematuramente aspectos da experiência que possam ser julgados importantes ou relevantes (DRIESSNACK; SOUSA; MENDES, 2007).

Esse processo não aceita conceitos e explicações utilizados na vida diária, baseia-se em perguntas fundamentais e investigadoras a respeito da experiência vivida (POPE; MAYS, 2009).

É fundamental que a metodologia seja teórica e prática concomitantemente. As observações empíricas e as experiências vividas pelo pesquisador devem constituir seu ponto de partida, pois instrumentalizarão o pesquisador, para observar e analisar a realidade de modo teórico desde o princípio (MARTINS; BICUDO, 2005).

A pesquisa qualitativa tem sido amplamente usada pelos pesquisadores da enfermagem. Moreira, Lopes e Santos (2013) argumentam que esse tipo de pesquisa possui potencial capacidade de gerar e implementar projetos que proporcionem contribuições valiosas para a prática de enfermagem, bem como instituir 
estratégias, a fim de garantir seu financiamento junto aos órgãos de fomento.

Portanto, de acordo com essas premissas, a minha necessidade de compreender a experiência vivida pelo familiar levou-me a buscar, na pesquisa qualitativa, o referencial da fenomenologia enquanto método. Por ser intuitivo e descritivo, busca nortear o pesquisador por uma interrogação sobre o fenômeno que esteja sendo vivenciado pelo sujeito (ANGERAMI, 2007).

Para compreender a vivência do familiar de pacientes em fase terminal de vida, que enfrentam o processo de morrer no mundo do hospital, é fundamental que a minha atenção volte-se para a descrição da experiência vivida tal como ela é, como esse fenômeno mostra-se para o familiar, em sua essência.

A fenomenologia possui o propósito de descrever a estrutura total da experiência vivida, incluindo o significado que ela tem para os indivíduos que dela participam. Vem ao encontro do desígnio do estudo, por preocupar-se com a compreensão do fenômeno vivido, não por achar relações causais (DARTIGUES, 1992).

De acordo com Bicudo (1994), a fenomenologia constitui um modo que permite ao pesquisador pensar a realidade de forma rigorosa, empregando métodos e instrumentos que são próprios do fenômeno e do pesquisador, a fim de buscar o desvelar do fenômeno, o revelar da essência.

A pesquisa fenomenológica busca descrever como fenômenos específicos são vivenciados e experimentados pelo ser, mantendo o foco na representação da experiência no contexto vivido, ou seja, capturando a experiência vivida. Somente quem vive tal experiência, vivencia esse fenômeno, é confiavelmente capaz de responder à tal investigação (DRIESSNACK; SOUSA; MENDES, 2007).

A fenomenologia, do grego phainesthai (aquilo que se apresenta ou que se mostra, e logos, explicação ou estudo), afirma a importância dos fenômenos da consciência (MOREIRA, 2010). 
A fenomenologia, enquanto tradição de pesquisa filosófica, foi desenvolvida como uma alternativa para o paradigma positivista (MCCONNELL-HENRY; CHAPMAN; FRANCIS, 2009).

O grande idealizador foi Franz Brentano (1838-1917), contudo foi o matemático Edmund Husserl (1859-1938), seu discípulo, que, sob influência de Platão e Descartes, desenvolveu essa filosofia. Outros pensadores foram posteriormente influenciados por Husserl. Entre eles, estão Martin Heidegger, Alfred Schutz, Jean Paul Sartre, Maurice Merleau-Ponty (SILVA; LOPES; DINIZ, 2008).

Todos esses pensadores tornaram-se grandes nomes da fenomenologia, com maiores ou menores repercussões. Conquanto Martin Heidegger, assistente de Husserl, foi considerado o seu maior crítico, a tal ponto de Husserl ser considerado o criador da fenomenologia e Heidegger o transformador (MORAN, 2000).

Fundamentalmente, nem Husserl nem Heidegger tiveram como objetivo produzir metodologias. Sua proposta foi a de oferecer filosofias, que foram usadas como suporte para apoiar metodologias de pesquisa (MCCONNELL-HENRY; CHAPMAN; FRANCIS, 2009).

Edmund Husserl desenvolveu a fenomenologia transcendental. Vários anos depois, Martin Heidegger, fascinado pelo conceito da fenomenologia, mas com as tensões no que diz respeito ao ângulo de Husserl, desenvolveu a sua própria abordagem, a fenomenologia hermenêutica (MCCONNELL-HENRY; CHAPMAN; FRANCIS, 2009).

Edmund Husserl estabeleceu uma base segura, porém liberta de pressupostos, para a elaboração de novos conhecimentos das experiências humanas. Desenvolvendo a fenomenologia transcendental, defendeu que a percepção consciente deriva do conhecimento. Sustentou a ideia de que era necessário observar os fenômenos tais como mostravam-se para quem os observava. Se o fenômeno mostra-se enquanto dado, pode e deve ser analisado em busca da verdadeira realidade, independentemente de ser fato (MCCONNELL-HENRY; CHAPMAN; FRANCIS, 2009). 
Para Husserl, os pesquisadores positivistas não compreendiam que cada objeto sensível e individual possui uma essência. Assim, confundiam o ver em geral com o olhar meramente sensível e experimental (MCCONNELL-HENRY; CHAPMAN; FRANCIS, 2009).

Sua proposta era a de abordar o mundo pré-reflexivamente. Devido a isso, defendeu o uso da epoché fenomenológica, também denominada de redução. (MCCONNELL-HENRY; CHAPMAN; FRANCIS, 2009). Epoché é relativa à abstenção de juízos préconcebidos e de ideias prévias, a fim de permitir a emergência do fenômeno em sua facticidade. (MARTINS; BICUDO, 1983).

A descrição fenomenológica proposta por Husserl foi a de ir às coisas mesmas (zu dem Sache selbst), o que possibilitou evidenciar o fenômeno em si mesmo que, com o olhar habitual, não era possível. Nessa abordagem, o pesquisador considera sua vivência em seu mundo da vida (Lebenswelt) uma experiência que the é própria, permitindo-lhe questionar o fenômeno que deseja compreender (SILVA; LOPES; DINIZ, 2008).

$A$ experiência não se refere somente aos fatos, mas à visão que se constitui na consciência. A explicitação, na consciência, dessa experiência obedece a princípios que regem as relações, intuitivamente percebidas de essência (JOSGRILBERG, 2000).

A essência de um ser caracteriza-se como um conjunto de significados que é compreendido, porque é vivido pela existência humana concreta. A descrição dos atos da consciência permite compreender como a essência constitui-se e como funciona de modo agregado entre o subjetivo e o objetivo, como está ligada ao mundo, aos homens e às coisas (CAPALBO, 1994).

A fenomenologia permite ao pesquisador buscar reavivar, tematizar e compreender eideticamente os fenômenos da vida cotidiana do ser, à medida que são vividos, experienciados e conscientemente percebidos, ou seja, apropriar-se do fenômeno posto e estudá-lo de forma sistemática, a fim de compreender o 
objeto na sua essência, deixando de lado a experiência empírica e assumir-se a experiência consciente. Eidético refere-se à essência do fenômeno (MARTINS; BICUDO, 2005).

A compreensão do referencial fenomenológico permitiu-me uma mudança de atitude, proporcionando uma imersão profunda no entendimento dos significados atribuídos pelos familiares na experiência vivida e uma valorização das relações enquanto ser-nomundo, inserido em um contexto histórico e cultural, imprescindíveis para o desvelar do fenômeno proposto neste estudo.

A escolha do referencial teórico-filosófico, que será discorrido a seguir, deu-se diante da compreensão de que eu necessitaria apoiar-me em um referencial que me orientasse o caminho, tendo como pressuposto o trazer à luz as minhas inquietações $e$ questionamentos, permitindo compreender a experiência vivenciada por esses familiares, pois são seres existenciais que, por meio da sua consciência, atribuem significados aos fenômenos vividos.

\subsection{A OPÇÃO PELA FENOMENOLOGIA HEIDEGGERIANA}

Foi de maneira desafiadora que optei por desenvolver este estudo pelo ângulo da visão existencial, tendo o referencial filosófico de Martin Heidegger, expresso em sua obra "Ser e Tempo", como suporte para a análise e a interpretação dos significados emergidos dos depoimentos colhidos. Considerando que esse filósofo não separa a emoção da razão e interroga o modo de ser na existência, questionando e refletindo sobre o sentido da existência humana, seu fundamento e valor, como também a respectiva responsabilidade do próprio homem frente à sua existência, elucidando que o ser faz-se da totalidade que apreende em seu próprio ser, baseando-se na forma essencial de viver, fundamentada de diversas maneiras.

Os princípios do pensamento heideggeriano foram ao encontro do meu propósito, pelo fato de que os conceitos filosóficos existenciais ajustavam-se às minhas inquietações e poderiam 
ajudar-me a desvelar o fenômeno vivido pelos familiares de pacientes em fase terminal de vida, que enfrentam o processo de morrer no mundo do hospital. Assim, a fenomenologia heideggeriana foi utilizada para a fundamentação teórica filosófica do estudo, fornecendo um fio norteador e condutor para a análise e a interpretação dos significados que emergiram dos depoimentos obtidos com os familiares do estudo.

Buscando aproximar-me do conhecimento e da compreensão do fenômeno vivido pelo familiar que vivencia essa experiência, passo, a seguir, a discorrer brevemente sobre a fenomenologia heideggeriana e alguns de seus conceitos que acredito serem capazes de fornecer-me a sustentação teórica necessária, para alcançar o propósito deste estudo. Dentre eles, ofereço destaque a alguns, com a intenção de expor o homem como sendo "ser-aí", Dasein, enquanto ser existencial, como "ser-no-mundo" e "ser-comoutro", e finalizo com uma abordagem sobre a questão do "ser-paraa-morte".

Martin Heidegger foi um importante filósofo alemão, nasceu em 1889 e morreu em 1976. É considerado um dos maiores pensadores do séc. XX. Após abandonar os termos consciência e intencionalidade, centrais na fenomenologia transcendental de Husserl, desenvolveu uma fenomenologia própria, motivado por uma profunda insatisfação ao tom metafísico husserliano em sua busca das essências da consciência (MORAN, 2000).

As fenomenologias dos dois filósofos diferem quanto ao local onde as coisas dão-se. Enquanto para Husserl reside na consciência transcendental; para Heidegger, dá-se no mundo (SILVA, 2002).

Durán et al. (2012) afirmam que Heidegger propôs constituir conhecimentos filosóficos que valorizem o contexto da experiência vivida no fenômeno, assim como os das experiências anteriores do próprio pesquisador. 
A utilização dos conceitos heideggerianos, na pesquisa, procura elucidar o sentido do ser, partindo das situações experienciadas por ele.

Assim, a fenomenologia para Heidegger (2011) é deixar e fazer ver por si próprio aquilo que se mostra, tal como se mostra a partir de si mesmo. É um caminho que não possibilita compreender o "quê" dos objetos da investigação, mas o "como se mostra", baseando nele próprio e no como o ser experiência o mundo.

De tal modo, objeto da fenomenologia heideggeriana é mostrar aquilo que, estando oculto e encoberto, constitui a essência. O essencial e fundamental é o ser mesmo, encontrado no fenômeno, no entanto tal ser é sempre ser de um ente (HEIDEGGER, 2011).

Seguindo esse pensamento, o fenômeno não se mostra diretamente, mantém-se velado frente ao que se mostra; concomitante, manifesta-se diretamente de modo a constituir o seu sentido (SILVA; LOPES; DINIZ, 2008).

Na obra Ser e tempo, usada para dar suporte a este estudo, Heidegger propôs-se a analisar o modo como o ser vivencia suas experiências à medida que toma consciência do seu estar-lançadono-mundo, ou seja, refere-se ao modo de ser do homem no mundo (ALVES, 2006). Nessa obra, o filósofo supera o conceito de consciência e propõe o conceito de Dasein (MORAN, 2000). Assim, direciona-se de uma fenomenologia hermenêutica para uma ontologia fundamental do ser (HEIDEGGER, 2011), através do qual nos possibilita compreender a existência humana (SILVA, 2002).

O método ontológico proposto por Heidegger parte de uma compreensão vaga do ser e permite chegar à compreensão do ser, partindo da descrição das situações vivenciadas pelo homem. Constitui-se em questionar o ser, interrogando o ente e buscando 0 sentido do ser. Tem como objetivo descrever, explicar e compreender as diversas manifestações do sentido do ser, em todas as suas dimensões e, para tanto, inicia da interrogação do que ele denomina de Dasein, ou "ser-aí" (DUARTE; ROCHA, 2011). 
Dasein é composta por "da" que significa "aí" e "sein" que significa "ser". Logo Da-sein constitui a existência e o ser-que-estáaí, ou ser-aí, ou ainda presença. Assim, a análise do Dasein é a análise da existência e do ser (DUARTE; NAVES, 2010).

Sobre Inwood (2002), acrescenta que é entendido como uma forma de unificação do homem, evitando-se a separação entre o corpo, a alma e o espírito.

A existência é o modo de ser do próprio Dasein e existir é apropriar-se de si mesmo, através das relações consigo mesmo (DUBOIS, 2004).

Para Heidegger (2011), as características fundamentais que permitem ao ser-aí manifestar-se são chamadas de ontológicas ou existenciálias, ele parte da vida cotidiana para mostrar os fenômenos ônticos e seus aspectos ontológicos. Tudo que o ser percebe, entende ou conhece de imediato é ôntico. Por conseguinte, o ontológico é aquilo que possibilita as várias maneiras de algo tornarse manifesto, produzido, presente, atuado, sentido.

Portanto, para o filósofo, se as características ontológicas desvelam o ser-aí, em sua concretude, os aspectos ônticos referemse ao ente.

Entes, enquanto campo de investigação das ciências ônticas, é tudo aquilo que falamos, mencionamos, assim como a gente mesmo e a nossa maneira de ser. O ser está implícito no "que é", e no "como é" alguma coisa, na realidade, no sentido mais restrito, no que "há".

O Dasein é considerado um ser privilegiado, por ser capaz de questionar e compreender o ser. É o homem ao passo que existe na existência cotidiana, juntamente com os outros entes envolvidos nas suas tarefas e preocupações. Entretanto, para estudar o Dasein, é necessária uma análise existencial, explorando o vínculo das estruturas que definem sua existência, os existenciais (DUARTE; NAVES, 2010). 
O ser-aí é um ser existencial, um ser-no-mundo, que significa diversas maneiras como o homem vive ou pode viver, os diversos modos como ele se relaciona e convive com os outros com quem ele se depara ou a ele se apresentam.

Ser-no-mundo é uma característica desvelada pela estrutura fundamental do Dasein, refere-se a uma descrição primordial na existência do homem que o limita e torna-o possível (DUARTE; NAVES, 2010).

Os autores ainda afirmam que o Dasein está no mundo na forma dos existenciais. Mesmo que esteja lançado no mundo, não é posto como vítima do acaso, é agente de transformação. Conforme suas necessidades, proporciona a organização das coisas, pois somente o Dasein é capaz de criar e dar sentido aos seus projetos, e concretizar-se, através do mundo que o rodeia. Desse modo, o mundo é definido para o Dasein pelo modo imediato como ele se relaciona com o mundo no seu cotidiano no mundo. $\mathrm{O}$ homem pode realizar-se no mundo como Dasein, sob a forma de ser-no-mundo, como ser existente. Porém o ser no mundo é, por essência, um sercom-outro, um ser que se relaciona e que não vive só, mas compartilha o mundo (DUARTE; NAVES, 2010).

De acordo com Heidegger (2011), para o homem, o estar no mundo não é um acaso, é algo que efetivamente o constitui. Vivenciar o mundo é relacionar-se com objetos e pessoas, é estarcom outros, onde a presença do ser-no-mundo é ser-com, é compartilhar o mundo-com-outros. É estar no mundo e habitar o mundo, e não apenas povoar um mundo dado. É algo que demonstra uma estrutura fundamental do ser-aí, que indica a impossibilidade de separar o homem do mundo, assim como o mundo do homem. Desse modo, compreende tudo que the é próximo, significando que o ser-com o cotidiano torna-se o ser da relação.

Duarte e Naves (2010) acrescentam que, para o Dasein, o que define o mundo advém do modo como ele se relaciona de modo 
imediato com o mundo no seu cotidiano. Portanto é possível considerar a realização do homem sobre a terra como Dasein enquanto "ser-no-mundo", o modo de ser que o torna existente, devendo ser considerado que o "ser-no-mundo" é um "ser-comoutro", portanto relaciona-se e compartilha o mundo onde vive com outros entes, denotando, assim, um caráter social do Dasein.

Por possuir a característica básica de abertura, para perceber e responder a tudo que está a sua volta, o Dasein constitui-se como um ser-no-mundo, constituído por um mundo que se manifesta principalmente pela existência de outros entes com o modo de ser, o qual Heidegger denomina de "ser-com" e "estar-ai-com". A existência é "ser-no-mundo", ser entre os outros, pois não existe um ser sem mundo, isolado, sem os outros.

A relação no mundo dá-se entre o homem e os outros, referindo $o$ ato de tomar conta dos outros, que constitui a estrutura fundamental de todas as possíveis relações entre os homens. Essas relações podem apresentar-se significando abstrair aos outros os seus problemas, ou auxiliar os outros para assumir seus próprios problemas. Heidegger ressalta que estamos sempre "sendo-unscom-os-outros", nas diversidades possíveis da solicitude.

Duarte e Naves (2010) argumentam que a existência deve ser algo para ser vivido de forma pessoal, no mundo construído pelo próprio Dasein, no entanto com consciência de "ser-com-outro", o que, de certa maneira, auxilia na afirmação do próprio Dasein. Por outro lado, os daseins também podem construir uma relação na qual sejam utilizadas as coisas, de modo que contribuam para a satisfação de ambos. Dessa forma, o dasein estabelece-se como um ser de relações, no universo composto por objetos e com os seus semelhantes.

Os autores acrescentam que não existe Dasein como ser-nomundo, se este não se concretizar como ser-com-outro, pois isso é essencial ao sentido do ser, independente da proximidade desse outro. 
O fato é que o autêntico "ser-com-outros" transforma-se em mero "ser-entre-outros", por conseguinte, em inautenticidade. Ou seja, a forma inautêntica de coexistência refere-se ao "estar juntos", sem existir uma preocupação em demasia com os outros, ou com as coisas que estes devem proporcionar. Ao passo que a forma autêntica é o verdadeiro "coexistir", abre-se aos outros a possibilidade de encontrarem a si mesmos e realizarem o seu próprio ser.

O homem, fundamentalmente por sua natureza humana, é um ser-no-mundo em constante movimento existencial que inclui, ambos, a autenticidade e a inautenticidade. É o único ser que se interroga, garantindo-se de seu próprio ser. Destarte, o "ser-aí" é compreendido sempre com base em sua existência, ou seja, fundamentado na possibilidade de ser ele próprio, ou não. A factualidade da existência é o seu estar lançado no mundo em meio aos outros existentes, no mesmo nível destes.

Sua essência está na sua existência e compreende a si mesmo, baseando-se em sua existência. Pelo qual o "ser-ai", em sua essência, compreende e interpreta o mundo constantemente e tem a possibilidade de compreender a si mesmo.

Nessa linha de pensamento, a palavra existência não mantém ligação com o conceito habitual e clássico da palavra, que denota "realidade", contrapondo-se ao conceito "essência". Existência, proveniente do verbo eksistere; ek-sistência, é algo que emerge, manifesta-se, desvela-se. Portanto, existência denota compreender o emergir do ser, que é descoberta pelo homem anteriormente a toda definição de si próprio, antes de todo o pensamento e linguagem (CARVALHO, 2003).

O existencialismo considera cada ser humano como um ser único, mentor de seus atos e de seu destino, a esse ser é permitido atribuir significados aos fenômenos existenciais com os quais se depara em seu cotidiano (HEIDEGGER, 2011). 
Com base nesse pensamento, no estudo realizado, o familiar do paciente em fase terminal de vida, tem a liberdade e a subjetividade própria do ser, ao vivenciar o processo de morrer. Sendo assim, a análise da existência foi conduzida à luz do modo de ser do familiar no mundo. Não foi, portanto, um ingênuo esclarecimento ou interpretação dos modos como o família relaciona-se com o mundo, nas suas possibilidades cognitivas, emotivas e práticas. Simultaneamente, foram esclarecidos e interpretados os modos como o mundo manifesta-se e co-determina as suas possibilidades.

É plausível a afirmação que é indispensável ao Dasein o seu ser-no-mundo, que implica ser-com-outro. Por conseguinte, sendo, no mundo, imerso em existência inautêntica, em uma situação de decadência, o homem deve emergir em busca do seu verdadeiro caminho (DUARTE; NAVES, 2010).

Os mesmos autores referem que Heidegger referencia a angústia, enquanto estrutura fundamental, como meio que proporciona condição ao Dasein direcionar à autenticidade, permitindo ao Dasein livrar-se do peso imposto pela cotidianidade e o impessoal.

Comumente o Dasein não apreende o seu poder maior de liberdade. Através da angústia, é remetido para essa liberdade, assim como para a responsabilidade, obtendo, assim, a possibilidade de projetar-se para novas escolhas. Essa angústia proporciona uma aproximação do Dasein com a compreensão de sua finitude, com a possibilidade de assumir sua autenticidade. A angústia é totalmente fundamental na compreensão do homem (CESTARI, 2010).

No conceito de angústia, encontra-se o tom que determina a essência do ser-aí, oferecendo na fenomenologia uma possibilidade de compreensão clara da totalidade natural do Dasein. Assim, a angústia não é somente um fenômeno psicológico e ôntico, possui 
uma dimensão ontológica capaz de remeter-nos à totalidade da existência como ser-no-mundo (DUARTE; NAVES, 2010).

Os autores acrescentam que, na fenomenologia heideggeriana, a angústia apresenta-se essencialmente humana, considerando que o homem em sua existência tem o poder da compreensão do ser, enquanto ser existente no mundo em contrariedade do Rochedo e de Deus que são, porém não existem.

Pode ser traduzida como disposição, tonalidade afetiva, mas também como "sentir-se situado", é o modo pelo qual o Dasein encontra-se aberto diante do puro e simples fato de existir, diante ao fato que ele é (ARAÚJO, 2007).

$\mathrm{O}$ fato de o homem estar no mundo, enquanto possibilidade de ser, é fator gerador de angústia, que pode ser entendida como sentir-se carente no mundo, ou de temor indeterminado. Pois o temor, além de ser uma localização da angústia, tem o propósito de mascará-la (CARVALHO, 2003).

Duarte e Naves (2010) consideram importante salientar que a angústia não deve ser assumida como um mero temor, embora o temor apresente-se como fundamental mediante o qual o homem encontra-se no mundo. É importante considerar que o temor é um estágio mais suave da angústia.

O temor é uma disposição central na existência do ser, pelo fato de que manifesta o mundo no ato de fuga do ser-aí de si próprio. Há muito mais força de revelação do mundo no temor do que em qualquer outro tipo de acesso ao mundo, como na alegria ou na felicidade. Diante da angústia, o Dasein encontra-se essencialmente frente a si próprio e possui liberdade de escolha para o seu caminho. Em presença da possibilidade para um modo autêntico do Dasein (WERLE, 2003).

Pode ser traduzida como disposição, tonalidade afetiva, mas também como "sentir-se situado", é o modo pelo qual o Dasein encontra-se aberto diante do puro e simples fato de existir, diante ao fato que ele é (ARAÚJO, 2007). 
A angústia é a estrutura fundamental que, além de permitir ao Dasein assumir sua autenticidade, promove a aproximação da compreensão de sua finitude (HEIDEGGER, 2011).

Está intimamente relacionada ao temor da vida diante da possibilidade da finitude, embora não deva ser tomada como um mero temor (WERLE, 2003).

A finitude apresenta-se e é vivenciada como real e determinada como possibilidade na existência humana, embora se apresente indeterminada diante da nossa consciência. Heidegger caracteriza-a de forma singular, quando se remete ao fato de que o homem, na sua existência, está no mundo para a morte (HEIDEGGER, 2011).

Essa existência é descrita por Carvalho (2003) como sendo o projeto que construímos para o nosso futuro, declarando ser o esse o significado básico do modo de ser por antecipação, fator que vai distinguir o homem dos demais entes, inferindo que a existência está fundamentalmente relacionada com o tempo.

Para Heidegger, o Dasein apresenta-se "estranho" na angústia, que aquele define com um não sentir-se em casa. Por ser a angústia capaz colocar a existência diante de si mesma, promove ao Dasein um ir além de si mesmo, alcançando a transcendência. Só a angústia é capaz de revelar a autenticidade e a inautenticidade como possibilidade de seu ser.

O Dasein, por ser um ser-em, e estar sempre lançado no mundo, assume esse ser-lançado no projeto com consciência da sua situação de abandono, considerando que ser-aí é ser lançado no mundo para existir. Consciente de sua liberdade, é posto diante de suas possibilidades. Pelo sentimento da angústia, torna-se essencialmente ser de projeto.

É visível a prioridade do tempo como modo existencial no projeto e na possibilidade que se faz do futuro. É necessário que, para viver autenticamente a condição de ser-para-a-morte, o homem necessita retomar-se a cada momento, por ser o único ente capaz 
de unir o conscientemente entre o que é e o que já foi. Fazer-se presente, com o propósito de viver autenticamente sua situação, é olhar sempre para si e para outrem, tornando o presente uma mistura de retomada do passado e de antecipação do futuro (CARVALHO, 2003). O autor afirma ainda que a situação existencial é inseparável da temporalidade, pois o tempo junta os sentidos do existir, logo é ele o sentido da existência.

O Dasein possui a capacidade de transcender diante de suas possibilidades e capacidades. Para isso, é necessário esforços e renúncias durante a sua existência. É na transcendência que o Dasein é chamado a conferir significação à sua existência, no qual enquanto ser-no-mundo, inautêntico, angustia-se e contempla toda sua existência, além de temporal e de ser-para-a-morte (DUARTE; NAVAES, 2010).

Porém um melhor entendimento do Dasein pode ser alcançado, quando visto como ser-para-a-morte, que possui finitude e uma relação concreta com o sentido do ser em geral, conforme será discutido a seguir.

\section{A existência autêntica como um ser-para-a-morte}

Enquanto fim da presença, a morte é a possibilidade mais própria, irremissível, certa e, como tal, indeterminada e insuperável da presença (HEIDEGGER, 2011, p. 335).

Meu propósito não está restrito simplesmente à intenção de expor os pensamentos de Heidegger, a fim de legitimar a concepção dos seus princípios filosóficos referentes à morte. Mas, sim, aproximar-me do seu modo de pensar e buscar nele uma forma de transpor o conhecimento adquirido para uma real possibilidade de compreensão do sentido verdadeiro, do ser-no-mundo, diante do processo de morrer, para, assim, desvelar o fenômeno vivido pelos familiares que fazem parte deste estudo. 
Portanto, parto do pressuposto de que o familiar é um ser-nomundo e também é um ser-para-a-morte, segundo a concepção heideggeriana.

Araújo (2007) afirma que, quando Heidegger discorre sobre a morte e a perspectiva da autenticidade, torna perceptível que sua análise pressupõe uma interpretação bem concisa, inferindo que a morte é a anulação absoluta do Dasein.

Para Heidegger (2011), a morte é uma possibilidade ontológica que deve ser assumida pela própria presença. Nessa possibilidade, o estar-presente apresenta-se ameaçado, visto que considera que a existência é totalmente afetada por morte, ou pelo ser-para-a-morte. Assim, define a morte como um fenômeno da vida, pois o ser é, por si, um ser-no-mundo, e o estar-no-mundo é viver, e a morte é a possibilidade da impossibilidade de existir.

Assim, o ser em sua existência é ser-no-mundo, inautêntico que possui a capacidade de angustiar-se, de contemplar toda sua estrutura e ainda pensar em sua temporalidade e de ser-para-amorte. Pela certeza desse processo, e tomando consciência desse fenômeno, enquanto ser essencialmente livre, obtém a propriedade de escolher entre encarar a morte, aceitando todo seu contexto, ou fazer-se indiferente ao inevitável, ou seja, da possibilidade de existir, da finitude que leva à interrupção de possibilidades diversas que ainda estavam por vir (DUARTE; NAVES, 2010).

O ser, na sua existência, percebe a morte como significado concreto da finitude, mantendo-a como parâmetro-limite para a criação e recriação da concepção humana. Se a existência, vista de modo singular, gera a angústia de um existir dependente do tempo, tal situação faz-se presente numa análise da existência finita, consciente de si. Assim, o homem é sujeito de todos os seus atos, construtor de seu vir a ser e, no limite da finitude, criador de sua liberdade (HEIDEGGER, 2011).

Segundo Heidegger (2011), há uma dificuldade existencial em sentir a experiência ontológica do morrer e da morte. Por 
conseguinte, tal processo conservar-se em suspensão, visto que representará o fim da estrutura do ser-no-mundo-com-os-outros.

A morte, embora certa, transforma-se num acontecimento público e de caráter impessoal, que concorda e incentiva a desejo de não tomar pra si a possibilidade de ser-para-a-morte.

Pois, no âmbito público, "morre-se", que se desvela e é compreendido como algo impessoal, não constituindo, portanto, uma ameaça. Pensar na morte é considerado medo covarde, atrela insegurança da presença a uma fuga apavorante do mundo e o impessoal não permite a coragem de assumir-se a angústia da morte (HEIDEGGER, 2011, p.329).

O Ser apropria-se da inautenticidade diante do fenômeno morte, uma vez que, diante das possibilidades expostas na sua existência, independente do projeto de viva, a morte apresenta-se como uma certeza. Em contrapartida, é-nos permitida a experiência da morte do outro, a qual é vivida como possibilidade existencial, desenvolvida e aprimorada à medida que vivemos.

A experiência da morte dos outros apresenta-se bem mais penetrante para o ser que a vivencia, uma vez que o findar da presença é acessivelmente sentido. Mesmo diante da morte dos outros, é expressa a fuga.

O fugir da morte disfarçando sua presença é insistente e frequente, no cotidiano dos que convivem com a morte dos outros "mais próximos". Constantemente, na tentativa de consolo, ainda convencem quem "está à morte" de que a morte não é certa e que o ser que "está à morte" haverá de regressar à sua cotidianidade serena (HEIDEGGUER, 2011, p. 329).

Essa tentativa de consolar e tranquilizar o ser que "está à morte" é, antes de tudo, uma tentativa própria de tranquilizarem-se a si mesmos, pois "o impessoal não permite a coragem de assumir a angústia com a morte" (HEIDEGGER, 2011, p. 330).

A morte revela-se enquanto perda experimentada na existência do ser que sofre a perda pela morte do outro, não se tem 
acesso à perda ontológica com tal, "sofrida" por quem morre. Pois não é permitido fazer a experiência da morte do outro. No máximo, estamos apenas "juntos" (HEIDEGGER, 2011, p.313).

Muito menos podemos assumir a morte do outro, morrer pelo outro no sentido ontológico. Pode-se "morrer por outrem", porém com uma conotação diferente, traduzindo-se sempre em sacrificarse pelo outro "numa coisa e causa determinada". Esse morrer pelo outro nunca pode denotar que a morte do outro tenha-lhe sido, de alguma maneira, retirada (HEIDEGGER, 2011, p. 314).

Em presença do ser-para-a-morte, o Dasein é impelido a decidir-se diante das demais possibilidades que se apresentam a ele, ou seja, escolher de qual forma conduzirá sua existência, pois ao chegar à morte, toda possibilidade ser-lhe-á definitivamente roubada, sejam elas quaisquer que sejam (DUARTE; NAVES, 2010).

Assim, a fenomenologia heideggeriana conduziu-me ao encontro das experiências dos familiares que vivenciaram 0 processo de morrer do seu familiar em seu mundo-vida, no qual, como sujeitos conscientes no mundo-vida, experienciaram essa situação, atribuindo-Ihe significados, conforme sua visão de mundo. Desse modo, permitiu-me traçar um caminho, um movimento de encontro dos fenômenos e buscar explicitar, compreender e interpretar os aspectos essenciais que afloraram nos discursos desses familiares sobre sua experiência vivida.

Essa experiência, no meu mundo-vida, constituiu bem mais que apenas $\mathrm{o}$ conhecimento das ideias que fundamentam a fenomenologia ontológica de Heidegger. Ela oportunizou uma transformação da minha visão em face do mundo. Conduziu-me à compreensão de que, diante da morte, o viver, de maneira autêntica, é viver consciente da finitude, encarando a morte como possibilidade da impossibilidade da sua existência, reconhecendo-me como serpara-a-morte. Consciente da minha finitude, projetar-me e estabelecer-me diante da possibilidade da minha vida, tendo 
intrínseco, na minha existência, que a morte deve ser vivida dia a dia, como possibilidade própria do Dasein.

Embasada nessa linha de pensamento, vislumbrei, na fenomenologia, a possibilidade de buscar a significação da experiência vivida pelos familiares no processo de morrer do seu familiar em fase final de vida, com base no vivido dentro do mundo do hospital, uma vez que a morte, além de ser uma experiência universal, vista pela lente da fenomenologia, é uma experiência única, por vezes, velada por sentimentos fragilizados.

Passo, a seguir, a apresentar o caminho metodológico, percurso pelo qual busquei a compreensão dos fenômenos. 
3 PERCORRENDO O CAMINHO METODOLÓGICO 


\section{PERCORRENDO O CAMINHO METODOLÓGICO}

\subsection{CENÁRIO E REGIÃO DE INQUÉRITO}

Este estudo teve como cenário 0 Hospital Universitário Professor Alberto Antunes - HUPAA, Maceió- AL. O HUPAA é um hospital-escola vinculado à Universidade Federal de Alagoas UFAL, embora, desde 29 de abril do ano de 2008, através da portaria n. .04 , da subsecretaria de Planejamento e Orçamento, tenha sido transformado em unidade gestora, passando a gerir seus processos administrativos e financeiros independentemente da UFAL.

Em maio de 2009, foi celebrado o 2.ำ convênio entre a Prefeitura de Maceió, a Secretaria Municipal de Saúde de Maceió e a UFAL/ HUPAA, o qual ratifica o papel da instituição como responsável pela assistência de média e alta complexidade, voltado às demandas existentes no Estado de Alagoas, na área da saúde e contribuindo para o fortalecimento do Sistema Único de Saúde SUS.

Caracteriza-se como um hospital-escola que se encontra em atividades de ensino, pesquisa e assistência, que representam o grande diferencial do HUPAA em relação aos demais hospitais dos diversos municípios de Alagoas, assumindo o compromisso da formação de profissionais da área de saúde.

O corpo funcional do HUPAA é formado por 1.117 profissionais capacitados, visando a um maior crescimento e desenvolvimento da saúde em Alagoas. O HUPAA conta com uma área construída de $26.974,22 \mathrm{~m}^{2}$, em seis pavimentos. Oferece um amplo leque de especialidades em suas consultas ambulatoriais, assim como os mais diversos serviços de diagnóstico e terapias. Atualmente, é composto por 196 leitos. Apresenta uma média anual de 6.887 internamentos. Vale uma ressalva em relação ao número 
de óbitos ocorridos: no ano de 2008, foram registrados 269 óbitos; no ano de 2009, foram 279 óbitos; no ano de 2010, foram 271 óbitos e 306 óbitos no ano de 2011.

Optei por incluir, neste estudo, apenas familiares de pacientes adultos, em fase terminal de vida que estavam internados na clínica médica (CLM), clínica cirúrgica (CLC) e Unidade de Terapia Intensiva - adulto (UTI-adulto), por serem esses os setores onde os referidos pacientes ficam internados nesse hospital.

A experiência do familiar que vivencia o processo de morrer do seu paciente em fase terminal, constituiu a região de inquérito deste estudo. Tal região necessariamente não se constitui em um espaço físico, mas de referência conceitual, local onde emergem as dúvidas e inquietações do pesquisador, em que as pessoas vivenciam suas experiências e expressam-nas ao investigador quando interrogadas (MERIGUI, 2003).

\subsection{SUJEITOS DO ESTUDO}

Os sujeitos do estudo foram 15 familiares que estavam acompanhando seus pacientes em fase terminal de vida, que enfrentavam o processo de morrer no HUPAA, Maceió - Alagoas.

Após conversa com os profissionais da enfermagem, psicologia e com o médico assistente, foram selecionados os pacientes em fase terminal de vida, e que seus familiares estavam cientes do estágio da doença, assim como o prognóstico de morte iminente.

A designação do familiar depoente deu-se em reunião prévia e informal, realizada pela pesquisadora, juntamente com um ou mais membros da equipe que prestava assistência ao paciente e com os familiares dos pacientes escolhidos. Foi considerado apto o familiar maior de 18 anos, que possuía grau de parentesco, ou vinculo afetivo com o paciente, sendo imprescindível que tivessem uma proximidade diária evidente com o paciente, estando presente no 
setor de internação, nos momentos da visita, ou como acompanhantes.

Ocorreu uma única vez a escolha de mais de um familiar por paciente, pelo fato de serem ambos aptos e mostrarem-se disponíveis e dispostos a participar do estudo.

\subsection{PRINCÍPIOS ÉTICOS}

Este estudo foi avaliado pelo Comitê de Ética em Pesquisa da Escola de Enfermagem da Universidade de São Paulo e obteve parecer favorável, sob o protocolo de $\mathrm{n}^{\circ}$. 193.455, em 05 de fevereiro de 2013 (Anexo A). E respeitou a Resolução n.ำ 466, de 12 de dezembro de 2012, que institui as Normas de Pesquisa em Saúde envolvendo seres humanos.

O Termo de Consentimento Livre e Esclarecido (TCLE) (Apêndice A) foi assinado em duas vias por todos os familiares entrevistados, sendo entregue a cada familiar uma via e a outra encontra-se arquivada pela pesquisadora.

No momento da assinatura do TCLE, os familiares foram esclarecidos quanto ao objetivo do estudo, assim como quanto ao direito de ter sanada qualquer dúvida, ou direito a outro esclarecimento, bastando entrar em contato com a pesquisadora, assim como sobre o direito de participar da mesma, ou não, sem penalização nenhuma a si ou ao seu familiar, e de solicitar o desligamento de sua participação a qualquer momento.

Foi garantida a manutenção do sigilo e anonimato quanto aos dados que possam identificá-los, garantido que as informações serão divulgadas apenas em eventos, ou publicações científicas.

Também foi esclarecido aos familiares sobre a não remuneração pela participação no estudo e que, em caso de desconforto emocional, receberiam atendimento psicológico no HUPAA. 


\subsection{OBTENDO OS DISCURSOS}

Após a escolha do familiar depoente, foi agendado um encontro para a realização da entrevista com local, data e horário que fossem convenientes para cada familiar. Que ocorreram ao longo do período de 05 de fevereiro a 30 de maio de 2013.

O número de familiares entrevistados foi determinado durante a coleta e a análise dos dados, a partir do momento em que o fenômeno foi sendo desvelado e as inquietações e o objetivo do estudo foram respondidos.

A questão norteadora do estudo estruturou-se de forma aberta, evitando-se preconceitos e pressupostos, com a finalidade de explicar o que ainda não era conhecido. A seguinte questão norteadora orientou os depoimentos dos familiares:

"Conte-me como é para você vivenciar a situação do seu familiar atualmente?"

$\mathrm{Na}$ ocasião, para facilitar o registro dos dados, foi solicitada a permissão para a utilização do aparelho MP3, a fim de registrar os discursos na íntegra, possibilitando a organização e a análise dos resultados. Todos os 15 familiares permitiram a gravação da entrevista e mostraram-se à vontade para expressar suas experiências.

A fim de garantir o anonimato, foi utilizada a letra " $F$ " (familiar) para a identificação dos depoentes do estudo, seguida de números arábicos, considerando a ordem em que as entrevistas foram realizadas (F1 a F15).

\subsection{CAMINHANDO PARA O MOMENTO DA ANÁLISE DOS DISCURSOS}

Para a análise dos discursos obtidos, utilizei os procedimentos preconizados pelo referencial de Josgrilberg (2000), inicialmente, foram realizadas leituras diversas de cada um dos discursos, das 
descrições das experiências vividas de cada familiar, sem preocupação ainda com a interpretação dos dados.

Após, realizei uma leitura atentiva, a fim de alcançar o sentido do ser de cada familiar. Busquei, em cada um dos depoimentos, a presença de algumas estruturas fundamentais da existência, delimitando as unidades de sentido.

Em seguida, selecionei, fenomenologicamente, por meio de uma categorização prévia das unidades de sentido, realizando uma seleção fenomenologicamente orientada, das unidades de sentido mais relevantes de cada um dos discursos para a elucidação dos fenômenos.

Por fim, as unidades de sentido contidas em cada discurso, foram agrupadas e relacionadas entre si, sem deixar de indicar os momentos que são específicos na narração de cada depoimento, interligando os sentidos que foram desvelados. Nessa fase, por meio desse agrupamento das unidades de sentido, emergiram as unidades temáticas, que foram denominadas de Unificações Ontológicas.

O referencial filosófico de Martin Heidegger, como supracitado, foi adotado para subsidiar a análise dos depoimentos. 


\section{TECENDO OS RESULTADOS}

\subsection{APRESENTANDO OS FAMILIARES}

Familiar 1(F1): "Às vezes eu fico triste, não é por mim, é por ela, é principalmente pelos meus netos."

F1, sexo feminino, mãe da paciente internada na UTI com diagnóstico de câncer de mama. Possui 49 anos, casada, atualmente reside na zona urbana de uma cidade do interior, no litoral de Alagoas, com o esposo, genro e os três netos, filhos da paciente interna. Possui $3 .^{\circ}$ grau completo, sua ocupação profissional atual é como professora em uma escola pública.

Familiar 2 (F2): "[...] a gente sempre quer que aconteça um milagre."

F2, sexo feminino, filha do paciente internado na Clínica Médica com diagnóstico de tumor renal. Possui 38 anos, atualmente reside na zona urbana de uma cidade do interior de Alagoas, próxima a Maceió, com seu esposo e filho. Possui $2^{\circ}$ grau completo, sua ocupação profissional atual é funcionária pública.

Familiar 3 (F3): "Aceitar que ela vai morrer, eu não aceito não, não aceito!"

F3, sexo feminino, filha da paciente internada na UTI com diagnóstico de câncer de pulmão. Possui 56 anos, solteira, atualmente reside na zona urbana de uma cidade do interior de Alagoas, com seus dois filhos adultos. Possui $1^{\circ}$ grau incompleto, não exerce ocupação profissional remunerada atualmente.

Familiar 4 (F4): "Mas tenho fé em Deus!"

F4, sexo feminino, esposa do paciente internado na UTI com diagnóstico de osteossarcoma. Possui 42 anos, casada, atualmente reside na zona urbana de Maceió, com sua filha de seis anos. Possui $2^{\circ}$ grau completo, sua ocupação profissional atual é de operadora de caixa de supermercado. 
Familiar 5 (F5): "Tem o dia de você perder, tem o dia de você ganhar as pessoas."

F5, sexo feminino, neta da paciente internada na Clínica Médica com diagnóstico de câncer de útero. Possui 26 anos, solteira, atualmente reside na zona urbana de Maceió, juntamente com a mãe e três filhos. Possui $2^{\circ}$ grau completo, sua ocupação profissional atual é de atendimento ao público.

Familiar 6 (F6): "É uma situação ruim, minha filha, porque é um caso que a gente não espera na família"

F6, sexo feminino, irmã da paciente internada na Clínica médica, com diagnóstico de câncer de ovário. Possui 41 anos, solteira, atualmente reside na zona urbana de uma cidade do interior de Alagoas juntamente com o pai, a mãe e os irmãos. Possui $1^{\circ} \mathrm{grau}$ completo, sua ocupação profissional atual é de empregada doméstica.

Familiar 7 (F7): "Eu só tô bem porque Deus é grande e me fortifica"

F7, sexo feminino, mãe da paciente internada na Clínica Médica com diagnóstico de câncer no intestino. Possui 62 anos, casada, atualmente reside na zona urbana de uma cidade do interior de Alagoas com o marido e filhos. Possui $1^{\circ}$ grau incompleto, não possui ocupação profissional atualmente.

Familiar 8 (F8): "É muito difícil ver ela assim, muito difícil, porque saber que é a minha mãe que está ali, assim, é muito difícil."

F8, sexo feminino, filha da paciente internada na Clínica Médica com diagnóstico de câncer de pulmão. Possui 25 anos, solteira, atualmente reside na zona urbana de Maceió, juntamente com a filha. Possui $2^{\circ}$ grau completo, sua ocupação profissional atual é caixa em uma casa lotérica. Pertence à religião católica.

Familiar 9 (F9): "Deus vai curar ele! Eu confio em Deus!"

F9, sexo feminino, irmã do paciente internado na Clínica Médica, com diagnóstico de câncer de pulmão. Possui 63 anos, solteira, atualmente reside na zona urbana de Maceió, juntamente 
com os filhos e os netos. Possui $1^{\circ}$ grau incompleto, sua ocupação profissional atual é aposentada pelo INSS.

Familiar 10 (F10): "Pra descrever como é pra mim vivenciar esta situação a primeira palavra é difícil!"

F10, sexo masculino, filho da paciente internada na UTI com diagnóstico de câncer de pulmão. Possui 19 anos, solteiro, atualmente reside na zona urbana de Maceió, juntamente com os pais, irmão e sobrinha. Possui $2^{\circ}$ grau completo, não exerce função profissional atualmente.

Familiar 11 (F11): "Mas tenho que estar segura, chorar na frente dela não, entendeu?"

F11, sexo feminino, filha da paciente internada na Clínica Médica com diagnóstico de câncer de útero. Possui 57 anos, solteira, atualmente reside na zona urbana de Maceió, juntamente com os filhos. Possui $1^{\circ}$ grau incompleto, sua ocupação profissional atual é empregada doméstica.

Familiar 12 (F12): "[..] dentro do hospital é difícil pro doente, pra você também é, porque você é responsável, você renunciou uma vida lá fora praticamente."

F12, sexo feminino, filha da paciente internado na Clínica Médica com diagnóstico de carcinoma basocelular. Possui 38 anos, casada, atualmente reside na zona urbana de uma cidade do interior de Alagoas, com os filhos. Possui $1^{\circ}$ grau incompleto, não exerce função profissional atualmente.

Familiar 13 (F13): "Eu vivi esta situação com meu pai e agora estou vivendo com o meu marido."

F13, sexo feminino, esposa do paciente internado na Clínica Médica com diagnóstico de câncer de pulmão. Possui 61 anos, casada, atualmente reside na zona urbana de uma cidade do interior de Alagoas próxima a Maceió, com o esposo. Possui $1^{\circ}$ grau incompleto, não exerce função profissional atualmente. 
Familiar 14 (F14): "O que eu pude fazer eu fiz, se ela se for hoje eu vou estar bem ciente que eu lutei e pelo menos morreu num hospital digno da doença dela."

F14, sexo feminino, cunhada da paciente internada na Clínica Médica com diagnóstico de câncer no intestino. Possui 32 anos, casada, atualmente reside na zona urbana de Maceió, com o esposo e filhos. Possui $1^{\circ}$ grau incompleto, não exerce função profissional atualmente, encontra-se afastada pelo INSS.

Familiar 15 (F15): "Mas eu sei que no momento da perda vai vir aquela força em mim porque eu vou saber que ele parou de sofrer."

F15, sexo feminino, filha do paciente internada na Clínica Médica com diagnóstico de câncer de rim. Possui 52 anos, divorciada, atualmente reside na zona urbana de Maceió, com o filho. Possui $3^{\circ}$ grau, não exerce função profissional atualmente, encontra-se afastada pelo INSS.

Após a apresentação dos familiares que me proporcionaram grandioso conhecimento das suas vivências referentes a um momento tão especial em suas vidas, serão discutidos, a seguir, os resultados desvelados sobre a vivência do familiar de pacientes em fase terminal de vida, que enfrentam o processo de morrer no mundo do hospital, sob a ótica dos conceitos fenomenológicos de Martin Heidegger. 


\subsection{CONSTRUINDO OS RESULTADOS RELACIONADOS AO FAMILIAR}

O caminho da ontologia fundamental de Martin Heidegger abriu-me inúmeras possibilidades para que eu pudesse compreender a vivência do familiar de pacientes em fase terminal de vida, que enfrentam o processo de morrer no mundo do hospital.

Os sentidos contidos nos depoimentos desvelaram o ser-nomundo familiar de um paciente em fase terminal de vida, que enfrenta o processo de morrer no mundo do hospital, por meio das estruturas fundamentais da existência, aqui trabalhadas como unificações ontológicas.

Apresento, a seguir, as Unificações Ontológicas, extraídas dos discursos:

\section{Manifestação de angústia dos familiares}

O ser-no-mundo familiar de um paciente em fase terminal de vida mostrou-se como é conviver com alguém que enfrenta o processo de morrer no mundo do hospital.

Compreendi a vivência do familiar, fenomenologicamente, a partir da qual foi possibilitada uma dimensão privilegiada, sendo desvelado que esse familiar percebe-se como um ser-para-a-morte, e esse fato passa a fazer parte de forma intensa na vida cotidiana de todos os envolvidos nessa experiência, que se apresenta de forma única e própria.

Heidegger (2011) aponta que morte é própria para cada ser. A possibilidade mais íntima do dasein. Cada um morre, e esse fato é inevitável, simplesmente é imposto. Independentemente do que se possa fazer, a morte acontece, e o ser é lançado na morte enquanto um ser-para-a-morte. Ao reconhecer a possibilidade da morte, o ser encontra sua autenticidade, e a angústia possibilita ao ser 
compreender a incerteza de sua existência, ou seja, assumir-se como um ser para a morte.

Essa experiência vivida pelo familiar na presença da morte retira-o da inautenticidade e torna-o consciente da individualidade da sua existência. Ao libertar-se da inautenticidade, o familiar direcionase de um modo de ser inautêntico rumo à autenticidade, desenvolvendo um movimento que expressa a dimensão da angústia, o que the permite ir ao encontro de si próprio.

Durante a experiência vivida pelo familiar, ao angustiar-se, ele está mergulhando em si mesmo, permitindo que tudo o demais permaneça suspenso. Desse modo, passa a obter a possibilidade de voltar-se para si, como ser único e singular, assumindo sua propriedade e decidindo sobre seus próprios caminhos.

Embora sua existência institua a dependência de outros, em seus discursos, os familiares expressaram seus sentimentos de um modo particular de ser e sentir a morte, quando diante da constatação da finitude do ser.

É muito difícil ver ela assim, muito difícil, porque saber que é a minha mãe que esta ali, assim, é muito difícil. E cada dia ela fica pior, cada dia piora, não tem melhora nunca [...]. Fico naquele desespero, sem saber o que vai acontecer, sem saber, mas já sabendo, só esperando o pior, venho todos os dias visitar ela. (F8)

É muito difícil! É um processo difícil, eu sei que pra todos que passam por isso, é difícil pra gente se recuperar também [...]. (F2)

A morte é esperada e considerada certa, embora não seja desejada, e o processo até a sua chegada é permeado por sentimentos complexos, intensos e difíceis de serem superados.

A cada momento em que uma pessoa morre, eu já fico pensando que podia ser o meu papai, 
que aquilo pode acontecer com ele a qualquer momento [...]. (F15)

Diante da possibilidade da morte como certa, ao anúncio da presença da morte no contexto em que o familiar tem vivido, colocao em sobressalto, temendo que, dessa vez, a morte tenha, de fato, vindo de encontro do seu familiar.

Ai, meu Deus! Eu não sabia, daí, quando minha tia me contou, acabou foi com tudo. Quando penso, a minha cabeça dói muito [...]. Não sei o que eu faço agora (choro). Eu tenho uma dor de cabeça, fico cansada. Meu coração bate forte, depois fico cansada. Ele bate forte e depois fico sem fôlego, que cansa. Quando dá alguma notícia ruim, eu fico logo como coração na mão, fico logo cansada. Aceitar que ela vai morrer, eu não aceito não, não aceito! Porque só tem ela, (choro) ela quem manda na casa e em todos, nos filhos todos é ela. (F3)

Em especial, essa fala chama atenção sobre o momento em que a familiar descobriu que a sua mãe estava em fase terminal de vida. Durante a entrevista, essa familiar demonstrou um profundo penar, fez uma pausa e chorou muito, prosseguiu com uma alteração no seu tom de voz, revelando, possivelmente, o quanto se encontrava desprovida de forças para enfrentar a facticidade da finitude.

Segundo o pensamento heideggeriano, nessa circunstância vivencial, o ser é lançado no mundo diante da facticidade da condição, de modo a ser entregue independentemente da sua escolha na situação vivida.

Até então, a morte parecia-lhe uma possibilidade distante, entretanto, ao tornar-se concreta na mundaneidade do ser-nomundo, filha de uma mãe em processo de morrer, fecha-se em si mesma, sendo assim impedida de compreender sua própria situação existencial, nega a si própria a verdade descortinada ao seu redor, como uma espécie de fuga. No cotidiano dessa fuga, a angústia 
pertence a constituição essencial da presença do familiar como serno-mundo diante da terminalidade.

Como a angústia é uma disposição fundamental que pertence à constituição essencial do familiar enquanto ser-no-mundo para a morte, está sempre de forma latente e determinando o ser-no-mundo que vem ao encontro na ocupação junto ao mundo e, como tal, pode sentir medo. Segundo Heidegger (2011, p.256), Medo é a angústia imprópria, entregue à decadência do "mundo" e, como tal, angústia nela mesma velada.

O medo apresenta-se para o familiar como uma condição, um modo de ser impessoal, no qual ele se percebe, quando diante da fase terminal de vida do seu familiar.

Esse medo evidencia-se nos relatos que desvelam o vivido diante da constatação da finitude do seu familiar, porém, além do medo, essa experiência também se revela permeada por outros diversos sentimentos intensos.

Os relatos demonstram, a seguir, como é a experiência de estar-no-mundo da doença terminal, vivenciando a iminência da morte do familiar que, até então, não sofria essa grave ameaça.

Um dia, ele chegou pra mim e disse: "Eu não aguento mais, estou muito debilitado, muito cansado". Olhei para ele e fiquei com o coração partido. Mas até aí, eu não sabia a gravidade, mas já me sentia com o coração triste só de ver ele sofrendo e não tendo melhora, até ao ponto que soubemos da gravidade. Depois que soubemos da gravidade, foi desesperador dentro de mim, muito desesperador [...] (F4)

Quando eu soube, foi uma reação muito triste, minha filha. Pensava que fosse outra coisa, mas não uma coisa tão grave. (F7)

Pra descrever como é pra vivenciar esta situação, a primeira palavra é "difícil". É muito sofrimento, porque começou com um problema no pulmão, aí tratou e a doutora disse que ela 
ficou boa. Daí, passado um tempo, acho que, assim, uns dois, quatro meses, daí ela começou a ter umas dorzinhas. Ela fez exames e não acusou nada, e de repente foi se agravando e deu no que deu. (F10)

O conhecimento da certeza da proximidade da morte chega para o familiar de forma avassaladora, pois, até então, a sua presença não era ameaça.

Os familiares encontram-se no mundo circundante, limitados pela nova conjuntura apresentada à sua existência. Mostram-se perplexos, temerosos e inconformados com a nova situação que Ihes fora imposta, enquanto ser-no-mundo familiar de um ente muito próximo que está com a predestinação de uma morte iminente, deixando evidente que não estão preparados para essa experiência.

$\mathrm{Na}$ analítica heideggeriana, ao ser lançado no mundo, sem que sua vontade tenha participado dessa escolha, o familiar vivencia sentimentos de natureza e intensidade variadas e relacionadas a fatos que, muitas vezes, descortinam um mal futuro (malum futurum), ou seja, estados afetivos que nos colocam diante da desnudez de nossa condição de seres humanos mortais.

Assim, o medo assume um significado existencial e temporal constituindo-se de um esquecimento de si mesmo e proporciona ao familiar não mais reconhecer-se em seu mundo circundante, impossibilitando-o de visualizar as diversas possibilidades que o circundam, pois esse estado torna-o um ser-no-mundo, aflito e conturbado, diante da probabilidade do não-pensado e não planejado estar concretizando-se.

Esse medo que se caracteriza como uma disposição imprópria para aquele que a vivencia pode ser observado, quando o familiar exprime como é estar enfrentando o processo de morrer.

Vivenciar a situação do meu familiar atualmente é muito difícil, principalmente pra mim que sou mãe. Ás vezes, eu penso, todos pensamos, que essa doença, de forma mais 
séria e mais grave, nunca vai acontecer na nossa família. Sabemos que pode acontecer, mas nunca pensamos que pode ser com a nossa família. Achamos que até os casos de doenças graves, acidente e de violência, nunca vão acontecer, que estão distantes de nós, e, quando acontecem, causam um grande abalo. (F1)

No caso desse relato, o estar enfrentando o processo de morrer da filha é uma situação que não segue o ciclo que consideramos normal na nossa existência.

Essa é considerada uma possibilidade que gera impacto interacional na família, em virtude do prolongamento da vida dos mais velhos e de presenciarem a morte dos filhos, o que pode gerar uma perda de difícil elaboração (KOVÁCS, 2008).

Mesmo quando se apresenta inserida no ciclo normal da vida familiar, a morte não costuma ser considerada como possibilidade, por vezes distante, chega sorrateiramente, decompondo a estrutura familiar.

É uma situação muito ruim minha "fia", porque é um caso assim que a gente não espera na família da gente, então, aparece um caso desses, a gente tem hora que não sabe nem como agir. [...] É muito difícil um caso desses, a gente pensa assim: " $A h$, isso não acontece na minha família! Mas é horrível! Parece, assim, quando você descobre, muda tudo, o quadro vira e mexe com a família inteira, e o pior de tudo é que ainda vem aquele medo, será que eu tenho? Será que a minha filha tem? [...].(F6)

Nos pressupostos filosóficos de Heidegger, o reconhecimento de que a morte está presente faz com que os familiares confrontemse com uma nova realidade, deixando claro que a morte que, até então, se apresentava como uma impossibilidade, agora deixa de ser uma possibilidade entre outras e passa a representar a 
perspectiva extrema do ser-aí, revelando-se como possibilidade mais própria, irremissível e insuperável.

A experiência vivenciada com a morte sempre advém da experiência da morte do outro, situação que nos remete à conscientização de que somos todos seres mortais, seres para a morte, e que, em algum momento da nossa existência, passaremos pelo processo de morrer, portanto no pensamento heideggeriano, um ser autêntico é um ser-para-a-morte.

Para Heidegger, a morte manifesta-se tal como o modo de ser que a vida assume, bastando estar vivo para morrer, e, como tal, deve-se assumi-la em caráter ontológico, próprio do ser. É a mais extrema das certezas, a possibilidade de não mais existir no mundo, que se apresenta e é a única possibilidade inexplicável e concreta da existência do homem.

Pelos relatos, nota-se que os familiares possuem consciência da finitude humana, embora não queiram que esse momento aproxime-se, porém reconhecem que a morte faz parte do ciclo da vida:

Quando chegar a hora dele, ele vai porque, como eu, como a senhora, quando chegar a nossa hora a gente vai, ninguém aceita, é uma coisa que a gente nunca aceita, [...]. (F9)

Essa é nossa vida, a gente tem que passar por tudo isso, a vida não são flores. $E$ todos passam por tudo. Tem o dia de você perder, tem o dia de você ganhar as pessoas... o dia de você partir. Então, são todas elas bem emocionantes, às vezes, temos a felicidade quando nasce alguém ou a perda [...] mas é a vida! (F5)

Porém, reconhecem que não estão preparados para perder seu familiar, embora o sofrimento vivenciado pelo seu familiar com doença terminal seja um fator que cause impacto sobre seus 
sentimentos, afinal não querem que aquela pessoa amada permaneça imersa em um sofrimento intolerável.

Eu acho que, nesse momento, ninguém é forte, por mais que você esteja lutando, vendo que aquela pessoa está sofrendo, mas você não quer perder. A gente vai fazer o que pode, a gente só sabe que um dia ela vai ter que ir. $A$ gente não veio pra ficar aqui, a gente veio só pra passar uns tempos. A morada da gente não é aqui, a gente sabe que tá aqui, mas um dia a gente, com 40, 50, 70 anos, mas a gente vai. Todo mundo, é pai, é filho, mas a gente nunca tá preparado. (F11)

A médica conversou comigo e disse como a minha filha estava. [...] Pra mim, como mãe, é difícil. Eu peço a Deus pra aliviar as dores dela, perdoar os pecados [...]. Porque a morte vem pra todos, né? (F7)

Heidegger reconhece que a morte é geradora de angústia, mas não em seu sentido casual, e sim como uma abertura para a consciência de que, como ser lançado no mundo, existimos para o fim.

Essa certeza do fim gera um sentimento de perda e, quando expostas a essas situações, o familiar remete-se a pensar na fase posterior a morte.

É porque eu digo, meu Deus, se a minha filha for embora, o que vai ser de mim, porque eu vou ficar o tempo todo lembrando dela, a cada Natal, a cada coisa que ela gostava, sei lá, meu Deus, não sei. (F1)

Mas, ao mesmo tempo, é uma perda lastimável, porque foi uma pessoa que eu convivi muito tempo da minha vida (choro), é como se fosse a minha segunda mãe [...].(F5) 
Nós sempre fomos muito ligadas, [...] Perda de mãe é perda de tudo, mãe, amiga, tudo [...]. (F8)

Esse sentimento da perda proporciona aos familiares uma dor pelo futuro, sem aquela pessoa amada e imprescindível na sua existência, gerando uma impressão de dano particular, como se uma parte de si também fosse perdida, podendo vir a afetar posteriormente essa pessoa, induzindo a um sentimento de aniquilamento ante o mundo (KOURI, 2009).

A morte revela-se como perda, e, ao revelar-se, essa perda referida pelos familiares somente pode ser sentida por quem fica, conforme o pensamento heideggeriano, pois a morte existencial somente pode ser sentida por quem morre.

Entretanto, a consciência da certeza da morte somente estará presente para aqueles que passaram por experiências anteriores envolvendo alguém importante (PARKES, 2009).

Assim, quando a morte de um familiar já foi vivenciada anteriormente, ela poderá ser vivenciada de forma mais amena, com uma provável facilidade na sua aceitação.

Estou dizendo, tudo isso abala demais, a minha mãe tá muito conformada, não sei se quando a verdade chegar (...) Minha mãe, ela tá.[...]. (F2)

Porém, a morte, quando não vivenciada anteriormente, pode tornar-se uma experiência difícil.

[...] eu acho que em mim é porque não sei! Talvez porque na família mesmo, na família da minha mãe, meus irmãos, ele é o primeiro, eu acho que é um choque maior, porque a gente nunca sentiu uma perda na família, tem numa família longe que a gente vê de vez em quando. Família mesmo, ele é o primeiro. Por a gente ver ele forte, a pessoa que ele era antes, a gente não tá preparada para que fosse ele já. (F2) 
Eu nunca tive uma experiência assim, de morte de algum familiar antes, de alguém da família mesmo. Conviver desse jeito é a primeira vez. Primeira vez! [...] Eu sei que ela vai tá num lugar bem melhor. Eu sei, mas é difícil. Muito! Muito, muito, muito! (F5)

Assim, a dor diante da manifestação da morte que, até então, era desconhecida, enquanto fato familiar manifesta-se de forma consciente.

Essa consciência proporciona um distanciamento que se torna uma tentativa de fugir da angústia trazida pela presença da morte e da sua compreensão como possibilidade certa para o ser-no-mundo. A função do impessoal é barrar a coragem de assumir a angústia com a morte e encobrir o mais característico da morte, sua possibilidade a cada momento (HEIDEGGER, 2011).

Essa possibilidade permite ao ser angustiar-se, permeado pelo sentimento de concretude da finitude já conhecida no mundo, mas não experimentada no âmbito familiar. Sua proximidade é desvelada, a tensão, a insegurança, a vulnerabilidade $e$ as dificuldades são encontradas. Aquela experiência até então alheia, torna-se uma possibilidade do cotidiano e surge aniquilando os sonhos e as esperanças e um sentimento de estranheza radical que acaba invadindo o ser e tornando-o envolto em sua dor (SANTOS, 2009).

Consequentemente, a presença da possibilidade da morte destrói aquela segurança inabalável sobre o futuro, e o sentimento de angústia desponta, criando uma situação palpável, vivenciada e percebida como privação.

Dessa forma, nota-se, nos relatos, que os familiares não se conformam que aquele familiar com um futuro promissor pela frente seja privado de concretizar seus sonhos.

E a minha maior dor é ver esse sonho da minha filha ser frustrado. Os sonhos dela assim 
tão jovem e os filhos. Eu creio que ela tinha, tem planos de ver o casamento dos filhos, os netos. Eu creio então toda a minha dor é essa. (F1)

Oh, gente, se preparem, hoje ela tá com um sorriso, amanhã vem uma tristeza. [...] Foi rápido demais, muito rápido. Ela é nova, solteira, ela ia casar agora esse mês, fez a casa, já tinha a lista de convidados, as testemunhas e tudo, ela ia casar. Já estava tudo preparado! [...] E de uma hora pra outra veio assim justo na irmã mais nova, aí é difícil. (F6)

[...] ela era forte e bonita. Aí você vê ela assim hoje e você não acredita. Daí saber que ela vai morrer é pior ainda, de ontem pra hoje ela piorou muito, a gente só está esperando. (F14)

De certa forma, a morte no cotidiano caracteriza-se como uma improbabilidade, baseada na confiança dessa hipótese, a segurança e a confiança na realização dos sonhos traçados para o futuro são mantidas, todavia, ao ver-se diante da simples ameaça da presença da morte, o ser manifesta um sentimento de agonia (SANTOS; SALES, 2011).

Caso o ser-para-a-morte tenha que considerar a morte enquanto possibilidade, compreendendo-a como tal, a possibilidade deve ser compreendida sem nenhum atenuante, e construída como possibilidade, diante dela, "suportada como possibilidade" (Heidegger, 2011, pag. 338).

Para Heidegger (2011), o ser-para-a-morte é essencialmente angústia, e a plenitude do seu ser somente é alcançada exatamente nessa angústia, deixando penetrar no mais particular e íntimo do seu ser. Ao assumir a morte e reconhecê-la como rigorosamente pessoal, um evento ímpar e último de sua vida, o Dasein deixa de temer a morte e alcança sua autenticidade. Nesse momento já não a teme mais. 
Ao possuir a certeza da morte, como defesa ao sentimento de invulnerabilidade, o homem busca incansavelmente negar essa ideia, porém, ao reconhecer a finitude como fato, os familiares sentem a necessidade existencial desse chegar-ao-fim (OLIVEIRA, 2012).

Com base nessa concepção, percebo, nos relatos, que a morte é compreendida como possibilidade pelos familiares que acompanharam todo o processo do tratamento e presenciaram o sofrimento vivido.

Na minha família, a gente está tentando ver o lado bom, porque, se ela falecer, não vai ter mais, como é que se diz, ela não vai mais sofrer com essa dor, que ela estava sofrendo muito $[\ldots]$. (F5)

Eu confio no senhor. Com Deus no coração, eu me sinto preparada. Acho que é melhor do que ver ele naquela situação, naquele sofrimento que ele está vivendo. Porque a dor dele é muito grande, desde que ele chegou aqui ele não comeu mais, só na mangueira. Sei lá, meu Deus! (F13)

Deus viu que ele já sofreu tanto, que teve misericórdia dele, e eu sei que, como filha, eu vou chorar, mas o que eu vou fazer vai ser pedir a Deus pra dar um bom lugar a ele. [...] que ele parou de sofrer. (F15)

Nas verbalizações dos familiares, foi desvelado que eles se encontram cansados de ver o sofrimento inserido em um processo de morrer prolongado e permeado de muito sofrimento e, implicitamente, consideraram a morte como uma possibilidade de alívio.

Kovács (2008) refere que o processo de morrer tem sido frequentemente prolongado pelo uso dos recursos tecnológicos disponíveis, implicando desgaste físico e psíquico de familiares, 
especialmente daqueles envolvidos nos cuidados diretos com o familiar.

De tal modo, nota-se que a situação existencial do ser-nomundo familiar de um paciente em processo de morrer, longo e sofrido, propiciou ao familiar um repensar da sua existência.

Nesse sentido, pelos depoimentos, compreende-se que os familiares reavaliaram aspectos relevantes não somente sobre a possibilidade da morte, mas maneiras diversas interligadas a sentimentos e emoções que ganham valor, quando o familiar relaciona-se com a morte, de tal modo que ela se revela para esse ser como possibilidade.

Esse momento existencial que o familiar vive diante da morte aproxima-o da condição de ser-para-a-morte, tornando-o, fenomenalmente, explícito como ser para a possibilidade da presença morte.

Ter um familiar em processo de morrer é uma experiência triste, complicada e difícil, que gera uma desordem na sua existência, provocando perplexidades, incertezas e consequentes alterações no modo de enfrentar a vida, possibilitando o reconhecimento da fragilidade da vida humana e a possibilidade de encará-la de forma diferente.

É uma coisa que você passa a valorizar cada dia da sua vida. Porque eu digo sempre à minha mãe, eu digo sempre: "Oh, mãe! A gente passando pelo que a gente está passando com o pai, é pra gente, todos os dias, valorizar a vida da gente, é pra gente fazer o que a gente quer, sair, a gente ver o que a gente quer ver, porque a gente não sabe de uma hora pra outra, como ele hoje, hoje ele quer comer uma coisa que ele não pode. Hoje ele quer ir pra um lugar que ele não pode. Então, tem que valorizar cada dia, cada dia. Eu disse assim pra minha mãe. E ela falou: "Esse ano foi o pior que eu tive na minha vida!" Mas eu retruquei e 
falei: "A senhora não deve dizer isso! Porque a senhora está viva!". (F2)

A doença é muito rápida. É muito rápida! Eu já estou pensando que posso ficar doente também. Porque eu estou me cuidando. Aí eu vou ver se não estou com a mesma doença também. [...] Porque você tem que dar valor à vida e se cuidar, não dá pra desperdiçar a vida e não dar valor pra saúde da pessoa. É, Deus sabe e há de saber o que a pessoa merece pelo valor que dá à vida. (F7)

A presença da morte foi capaz de propiciar o despertar para a própria finitude, ou seja, a presença da possibilidade da morte remete o familiar à insuperável possibilidade da sua própria morte, o que leva a repensar seus valores e crenças e pensar em transformar sua maneira de compreender e viver a vida.

A experiência diante da presença da morte proporciona ao ser uma reflexão sobre sua existência, despertando um repensar sobre todos os aspectos da vida, da morte e do tempo, despertando a necessidade de dar novo sentido para a sua existência (FREIRE, 2006).

Falar sobre aspectos interligados ao processo de morrer torna-se uma tarefa extensa, e, como extensa, fez-se necessário trabalhar com a imposição de alguns limites, embora, acredito, tenha sido desvelado como o ser-no-mundo familiar de um paciente em fase terminal de vida enfrenta o processo de morrer.

\section{Manifestação do Cuidado e da solicitude}

Ser-no-mundo é cuidar, é ser cuidadoso. O cuidado é, pois, o estado primordial do ser, do homem, no seu esforço em adquirir autenticidade, portanto, é o primeiro gesto da existência, o horizonte da transcendência. Apesar de cada um ter a sua visão de mundo, 
esse horizonte da transcendência é o mesmo para todos (SALES, 2008, p.566).

O ser-no-mundo familiar de um paciente em fase terminal de vida que enfrenta o processo de morrer no mundo do hospital vivencia um momento existencial muito especial, um momento de cuidar, tornando significativa a sua existência.

O cuidado e a solicitude manifestam-se durante essa experiência vivida, desvelando perspectivas que se referem ao familiar que cuida do seu paciente terminal em processo de morrer e a do familiar que necessita de cuidado durante essa experiência existencial.

O "cuidado", segundo o pensamento heideggeriano, é considerado como a essência da presença, um elemento estrutural da existência que se constitui pelo desvelo, zelo, atenção, afabilidade, atitudes que o ser disponibiliza, quando sai de si e vai ao encontro do outro com solicitude (preocupação) compreendida como colocar-se antecipadamente em relação a alguma coisa, no sentido de importar-se, ter o propósito de realizar algo, ou de ir em busca do cuidado.

Segundo Heidegger (2011), na solicitude, o ser possui duas possibilidades, a de fazer o cuidado pelo outro, substituindo-o, dominando-o, manipulando-o, ainda que seja de forma útil. Dessa forma, o outro pode tornar-se dependente e subjugado, mesmo que esse domínio seja tácito e permaneça velado.

Essa possibilidade é a que Heidegguer (2011) denomina de cuidado inautêntico. Nesse caso, o ser não se preocupa tanto com o outro, dando maior relevância às coisas que lhe deve proporcionar.

O cuidado inautêntico foi evidenciado nos depoimentos que os familiares referem sobre os momentos em que optaram por mascarar a gravidade da situação e omitir sobre o mal prognóstico da doença ao seu familiar, assim como sobre a possibilidade da morte iminente, buscando, com essa atitude, amenizar o sofrimento da proximidade da morte. 
Porque já é difícil pra eles vir visitar, eles vêm, mas eles ligam pra mim primeiro, eu converso com eles e eles já entram chorando, eu peço: "Não chore na frente dela não, pra ela não ficar tristinha!" E converso com eles antes, ai um vai olha pra ela assim, conversa com ela um pouquinho e sai, o outro vai, mas a demora deles é pouca, eles ficam mais do lado de fora e olhando assim de longe, porque eles se desesperam fácil. (F6)

Eu menti pra ela o tempo todo, até hoje eu minto pra ela. Digo que eu não sei qual a doença dela! Ela fala: "Me diz, o que é que eu tenho são gases?" Porque cresceu muito a barriga dela, eu ficava alisando a barriga dela ela gritava que só, e pra aliviar a dor eu alisava. Eu achava que aliviava, mas pra ela não. Eu tentava ser o máximo possível presente pra ela, ali no dia-a-dia com ela, alisando, alisando até ela dormir. Quando estava muito forte, aí as enfermeiras aplicavam a injeção. (F14)

Quando eu chego pra visitar ela, aqui no hospital, na UTI, eu me sinto mal, porque a gente olha assim e vê essa situação. Daí vem aquela emoção, aquela vontade de chorar $e$ tudo. Só que a gente segura pra não passar uma imagem pra ela de tristeza. (F10)

No dia em que recebi a notícia da gravidade do caso dele, foi muito triste. Eu soube dessa notícia, quando ele ainda estava na enfermaria. Foi quando a doença foi diagnosticada, daí eu fiquei desesperada, mas eu nunca tive a coragem de dizer nada pra ele. (F4)

Eu tô tentando não mostrar pra ela, que eu acho que se ela vê que o povo tá sofrendo (choro). Ela não sabe de nada, da gravidade dela, eu falo pra não contarem nada pra ela, $e$ esse é o meu maior sofrimento. Eu saber e não poder falar nada. (F5) 
Os familiares optam por omitir parcialmente, ou totalmente, sobre as informações da sua doença por julgarem que o paciente não suportaria saber a verdade sobre seu estado de saúde. Porém em alguns casos, essa decisão poderá gerar sentimentos de culpa e solidão, por não terem compartilhado com o seu familiar e terem que vivenciar os momentos da finitude com esse segredo (PEREIRA; DIAS, 2007).

Quando houver a opção pelo compartilhamento das informações sobre diagnóstico médico e prognóstico da doença, entre os familiares e o paciente em processo de morrer, deverá ser realizado gradualmente, considerando a adaptação, a compreensão e a necessidade do doente sobre essas informações (GOMES, 2010).

O compromisso de comunicar o diagnóstico ao paciente cabe ao profissional de saúde responsável pelo paciente, porém, quando em presença de um prognóstico desfavorável, é motivada a conversa com os familiares pela dificuldade em lidar com a morte e com o paciente terminal. Diante da negativa da família em repassar a notícia ao doente, constitui-se um alívio para o profissional, estabelecendo-se uma aliança de cumplicidade entre os familiares e o profissional (QUINTANA et al., 2006), embora, principalmente diante de uma doença terminal, seja necessário que uma relação entre os profissionais de saúde e os familiares seja estabelecida com base em uma confiança mútua na qual a comunicação seja instituída de forma clara, sincera, com informações concretas.

O que ocorre, porém, é que na dinâmica dos serviços de saúde, na maioria das vezes, não tem correspondido aos anseios dos familiares, para esclarecer suas dúvidas e minimizar suas preocupações. Esse é um fato observado desde a fase da descoberta da doença.

Conforme se constata nos depoimentos dos familiares, estes afirmam que sentem que a equipe de saúde não oferece 
informações precisas sobre o diagnóstico, tratando-os com indiferença, mantendo-os desconhecedores da real situação estabelecida no processo da doença, constituindo-se em uma solicitude inautêntica.

Agora eu não sei. Depois da cirurgia, eu fiquei pensando, ela ainda passou um mês em casa, um mês e ela tinha dores de cabeça. Eu não tô aqui colocando culpa em ninguém não, estou só desabafando. E ela vinha três a quatro vezes na semana aqui para este Hospital. E só veio fazer tomografia, porque a gente insistiu. Fez a tomografia e ainda foi pra casa. E a médica dizendo que não tinha nada. Sei lá como foi, alguma coisa assim. Agora eu li, eu como leiga em assunto de medicina, eu li e vi que tinha algo errado, eu li e vi que tinha. Falava que é pra a equipe médica observar, eu não sei muito bem, né, eu esqueci o que tem, eu só vi assim "nódulos", vi também pigmentos e olhando aquele coisa assim, a gente via os pontinhos na cabeça dela, na cabeça toda os pontinhos. (F1)

[...] e a gente luta tanto, já fomos pra tantos médicos que mandaram botar ele pra casa, botassem ele na UTI e falassem as coisas pra família, mas não. Não pode ser assim! [...]. (F9)

As preocupações dos familiares seriam minimizadas, e uma relação de confiança estabelecida, caso os profissionais esclarecessem as dúvidas e envolvessem a família no tratamento e nos cuidados com o paciente, considerando que o paciente depende fundamentalmente dele no cotidiano. Nesse caso, o não envolvimento torna-se inadequado.

Os profissionais de saúde necessitam refletir e despertar para o seu existir-no-mundo, alcançando a transcendência que os projetará em direção ao seu poder de ser autênticos, possibilitandoos saírem do vazio existencial e desvelarem-se a si para desvendar o mundo ao seu redor (SALES, 2008). 
Todavia, por considerarem que os familiares não possuem uma capacidade válida de cuidado, frequentemente a dinâmica dos serviços de saúde não tem correspondido aos anseios dos familiares no esclarecimento das dúvidas. Tendem a focalizar o cuidado no paciente, consequentemente, relevam o fato de que a doença é uma facticidade que abrange todo o sistema familiar, desestabilizando-os e colocando em risco as relações interpessoais, inclusive colocando em situação de ameaça a saúde dos familiares (SILVA, 2002).

A outra possibilidade de solicitude, ou cuidado, segundo Heidegger (2011), é a de possibilitar ao outro assumir sua própria existência, permitindo que cresça, amadureça, encontre-se e transcenda em seu ser. Essa é denominada de cuidado autêntico e ocorre, quando o ser não substitui o outro, mas antepõe-lhe as possibilidades de existência, sem a intenção de retirar-lhe o cuidado, e sim de devolvê-lo. Essa possibilidade de cuidado permite ajudar o outro a tomar para si seus próprios problemas, permitindo-o encontrar seu próprio ser.

Assim, o cuidado autêntico evidenciou-se nos discursos dos familiares sobre a experiência vivida, desde a descoberta da doença, durante o período do tratamento, até o momento que vivenciam atualmente, que se configura no processo de morrer do seu familiar.

Assim, acredito que os relatos, desde o princípio da trajetória vivida, são fundamentais, para o desvelar do fenômeno vivido por esses familiares no processo de morrer no mundo do hospital.

Foi evidenciado no depoimento desse familiar que o profissional compartilhou com a família as informações sobre o paciente no início do vínculo assistencial, possibilitando uma interação com o familiar e uma ação participativa no cuidado ao paciente em fase terminal.

E, quando a gente começou a tratar dele, ele já estava em estágio terminal, ai a gente pensava que era uma coisa, porque ficavam dizendo que é uma coisa, que é outra, e a gente pensava que não era uma coisa tão séria. Foi 
quando a médica dele conversou sobre o estado dele, ela me chamou quando fui com ele para o CACON, que era pra uma consulta, ai a médica me chamou, porque quem estava com ele era eu, botou ele na sala pra tomar a morfina dele, pra ele não ficar mais cansado. Foi quando ela disse que já não tinha mais oque fazer por ele, porque o estágio dele estava muito avançado. Ele estava muito debilitado, não tinha condições de reagir a nenhuma medicação. (F2)

Para Mendes e Andrade (2009), a decisão de não mais investir no paciente, no sentido de intervenções visando à cura, nunca deve ser tomada por um profissional isolado, necessita sempre ser realizada pela equipe de saúde, incluindo também o posicionamento da família.

Segundo Heidegger (2011), cuidar de alguém não consiste em ocupar-se, mas preocupar-se com essa pessoa, assim o cuidado com preocupação caracteriza a solicitude autêntica, distinguindo-o da ocupação desprovida de significação.

Nota-se, pelos depoimentos, que os familiares, diante da constatação de que a saúde estava ameaçada, assumiram uma atitude concreta, a fim de cuidar dos seus familiares.

Ela passou um tempo comigo, o marido praticamente não deu atenção, a sogra não apoia, ela tem dois filhos, uma pequenininha. Ela estava muito doente da cabeça, muito doente, muito agitada, ai eu fui buscar ela, pensando que só era depressão. [...] $A i$ chegando lá, uma hora dessas, ela estava desmaiada, vomitando sangue, não estava se alimentando, dai eu solicitei uma ambulância. Eu pedi lá no hospital psiquiátrico, dai levaram ela até o HGE e não levei exame nenhum, nem encaminhamento de nenhum médico. Cheguei lá só, com a cara e a coragem. Ela morrendo praticamente nos meus braços. $O$ médico disse que lá não era lugar pra ela. Eu disse que se lá 
não era lugar pra ela, era aonde então? [...] Fez um $R X$ que acusou metástase, [...] Ela esta com um tumor? Eu até agora não sabia, [...] Ele disse: "Então eu vou lhe dizer é um câncer, só que ela não vai poder ficar aqui, vai ser transferida e eu já vou pedir a transferência dela, vou pegar teu caso porque sei que você esta muito cansada." (F14)

Ela é minha mãe, ela descobriu esse tumor em janeiro. A médica pediu pra fazer a biópsia [...] dai descobriu esse tumor. [...] o tumor estava muito grande e tinha que fazer outro tratamento [...]. Ela fez a quimioterapia e a radioterapia. [...] Quando ela fazia, chegava em casa e agravava, eu levava ela pra o mini prontosocorro, lá perto de onde eu moro, lá ela passava a noite. Foi quando ela veio aqui pra minha casa. (F11)

Aí quando ela adoeceu, ligaram pra gente dizendo que ela tava internada por que adoeceu. Aí a gente foi atrás dela e o marido dela disse, que quem tem que tomar de conta dela era a família. Então, a gente, os irmãos e eu a mãe. A gente foi fazer por onde tomar de conta [...] (F7)

Durante o movimento de cuidar da saúde do seu familiar, surge a constatação da gravidade do diagnóstico, causando o primeiro impacto da doença na vida da família. Diante disso, os sentimentos de insegurança e sofrimento passam a ser companheiros constantes, enquanto permanecem imersos na responsabilidade de promover o cuidado.

Ao enfrentar a doença, passam a organizarem-se a partir dessa facticidade, assumindo a realidade que the foi imposta, relacionando-se com o mundo de uma maneira autêntica, isto é, acolhem a angústia e as suas revelações.

Abstraídos no compromisso de socorrer seu familiar que estava com a vida ameaçada, investiram, sem medir esforços, para 
vencer a luta contra a doença, dispondo de seus bens capitais, para a garantia de um tratamento de qualidade, porém esse fator não foi determinante para o êxito do objetivo proposto, enfatizam, ainda, que, nesse caminhar, a imprecisão no diagnóstico da doença mostrou-se como fator determinante para a impossibilidade da cura.

Faz um ano que ela está lutando contra essa doença, faz um ano. E a gente pagou tudo, foi tudo médico pago pra fazer exame, pra consulta, foi tudo pago, tudinho. Porque nós não esperava pelo SUS, não. Agora, depois a gente não teve mais. Aí foi o jeito, a gente gastou muito. (F3)

Porque ela estava com o seio normal, quando foi para a primeira médica, e a médica passou a biópsia. Ela ainda não veio na médica aqui do hospital, foi para outra médica, que passou uma biópsia, só que deu benigno, não sei como foi que fizeram. Gastou-se tanto e deu benigno. Só que progrediu depois que mexeu. (F1)

Diante da falta de condições econômicas, trilharam outros caminhos na busca da oportunidade de um tratamento digno, que propiciasse a possibilidade da cura, indo até a última instância, para legitimar o direito à saúde do seu familiar enquanto cidadão.

Constata-se, pelos depoimentos, que a forma como os serviços de saúde são organizados, a grande demanda de pessoas que nele buscam atendimento contribui para o difícil acesso.

Eu ainda procurei a Santa Casa pra pedir internamento, porque a pior coisa, quando a gente tá correndo atrás, e aquela pessoa tá doente. Aí, se ela morreu, você fez alguma coisa, você cumpriu com a sua parte, entendeu? Mas você ver aquela pessoa ali morrendo e você não poder fazer nada, e a pessoa ficar depois pensando, se eu tivesse corrido atrás, talvez. Mas ela está aí, eu batalhei, corri, nunca cheguei assim num 
negócio de justiça pra procurar nada, até hoje. Foi a primeira vez, foi pra ela para o internamento, mas só isso mesmo. (F11)

Aí a defensora disse: "Agora vamos dar um outro lá pro $\mathrm{HU}$, lá é lugar dela ficar. O HU, ou a Santa casa, mas já que teve este recurso todo na Santa Casa, vamos mandar para o HU". Eu trouxe o recurso pra aqui, entreguei nas mãos do secretário e da secretária do diretor daqui, e esperei um mês. Todos os dias eu ligava, enquanto isso ela estava no HGE. [...] Fiz a minha parte pra trazer ela pra um hospital melhor, pra ela morrer limpa e bem cuidada. (F14)

Na prática, os pacientes e seus familiares vêm implorando por atendimento nos hospitais públicos, não sendo acolhidos imediatamente, embora o artigo $5^{\circ}$, $\S 1^{\circ}$, da Constituição Federal garanta a inviolabilidade do direito à vida. Nesse caso, a busca pelo ajuizamento de ação judicial tem sido necessário, para alcançar seus direitos de poder lutar por um tratamento com dignidade e esperança.

Embora a decisão judicial, muitas vezes, torna-se ineficiente, dependendo do estágio da doença do paciente, pois além de demandar certo período de tempo, o serviço público pode não cumprir espontaneamente com a decisão judicial. $O$ ideal seria que os serviços públicos cumprissem com a ordem constitucional, prestando assistência necessária, evitando tamanho sofrimento para o paciente e seus familiares (ROSA, STURZA, 2013).

Após ter sido vencida a etapa da busca de um tratamento digno para seu familiar, os familiares passam a uma fase distinta na experiência que estão vivenciando.

Agora inseridos no ambiente hospitalar, mostram-se satisfeitos e agradecidos aos profissionais, enfatizando a sua percepção da forma como seu familiar está sendo cuidado pelos profissionais de saúde: 
[...] porque quando ela veio do (...) pra cá, ela chegou aqui completamente podre. Agradeço a Deus a cada enfermeiro a cada médico que vem acompanhando ela, todos, peço a Deus todos os dias, que ele abençoe a cada um, porque ela teve um bom tratamento aqui e está tendo, porque ainda está com vida. O que eu pude fazer eu fiz. Se ela se for hoje eu vou estar bem ciente que eu lutei e pelo menos morreu num hospital digno da doença dela. (F14)

Tá cuidado demais, demais, demais. Em casa, quando ele dizia, tão deixando eu morrer a míngua, eu dizia que não era a gente, não é a gente [...]. (F2)

Os familiares, quando inseridos no ambiente hospitalar, procuram observar se a equipe disponibiliza cuidados que viabilizem o bem-estar do seu paciente.

A partir dessa observação, o familiar estabelece o nível de segurança e confiança na equipe, que vai interferir na sua postura durante o período de internamento, podendo ser aliada à busca do bem-estar, ou tomar atitudes que venham a contribuir com a dificuldade do tratamento do seu familiar (KNOBEL; ANDREOLI; ERLICHMAN, 2008).

Nesse sentido, é indicado que os profissionais de saúde estabeleçam uma relação mútua de confiança e ajuda, com o familiar dando suporte para o enfrentamento da situação imposta durante o internamento (MARUITI; GALDEANO, 2007). Caso consiga estabelecer essa relação com os familiares, o profissional de saúde poderá desenvolver um plano de cuidados bem mais satisfatório, disponibilizando atenção, apoio, orientação, acolhimento e auxílio aos familiares em suas dificuldades, angústias, medos e dúvidas decorrentes da doença (LEAL et. al., 2009).

Conforme o familiar demonstra em seu depoimento, os familiares sentem-se mais próximos do paciente, quando 
profissionais aceitam sua participação, inserindo-os e incentivandoos a envolverem-se no cuidado.

Agora o jeito que tinha era com medicamento pra ir aliviando as dores dela, e ela também precisava da atenção de toda família. Aí desde que ela veio pra cá, já vai completando quase um mês, dei muita atenção, nós tudo aqui junto dela. (F7)

Porque enquanto o paciente ainda pode andar é o acompanhante que tem que fazer isso, e ele ainda anda, mas ta sendo muito difícil mesmo. (F12)

Esse mês que eu tô resolvendo esses problemas, é luta! As pernas ela não quer abrir a perna pra enfermeira limpar ela. Com ninguém da minha família ela quer. Não quer minhas filhas aqui, nem pra trocar uma fralda nela, aí fica tudo pra mim e pra minha filha. Só eu e minha filha que ela deixa, mas o resto das outras, as sobrinhas dela querem vir, mas ela não deixa nem pra trocar uma fralda dela, entendeu? Pra não verem ela pelada. (F11)

Santana (2008) salienta que manter o vínculo do familiar com o paciente tem fundamental importância na busca de cuidados para o paciente terminal. Segundo Gomes (2010) os últimos dias de vida devem ser para proporcionar paz, alívio, qualidade e dignidade de vida no processo de morrer, optando por um bem-estar físico e psicológico, a fim de refletir positivamente na condição do doente e da família

Foi observado, nos relatos, que o familiar não está preparado para desempenhar as atividades de cuidado, porém permanece imerso no propósito de cuidar do seu familiar até o fim.

Porque ele tem hemorragia em um tumor e, quando dá hemorragia, só Deus mesmo, porque os médicos estão lutando pra estancar, eu tenho que dar banho, estar lavando e vendo 
aquele negócio. Eu nunca me vi numa situação dessas e é difícil pra gente dar banho nele por causa dos curativos. Quando a gente tira, tem que ter muito cuidado. Uma vez eu tirei um curativo e o sangue jorrou e quase que eu me melava toda, aí, toda vez que eu vou dar o banho, eu fico com medo. Porque é a gente que tem que tirar, eles só vêm mesmo pra limpar mais e cobrir. (F12)

Sempre mamãe dizia que eu gostava mais de meu pai do que dela! E eu dizia que não. Mas, no fundo, meu pai era tudo pra mim, e pra ver ele como ele tá agora eu sofro cada vez mais, eu vejo as feridas dele, porque eu que levanto ele no banho. Os médicos dizem que está tudo sobre controle, mas a pessoa chora só de olhar. (F15)

Ela fica vomitando, aí deixo ela lá um pouquinho, aí depois tudo de novo, é assim que vou passar a noite toda com ela. Ás vezes, eu fico aqui de dia e, às vezes, eu fico de noite também. (F7)

A presença do familiar configura-se em uma necessidade, quando se busca continuidade dos cuidados no ambiente hospitalar. No entanto os familiares que prestam cuidados com o paciente em fase terminal necessitam de capacitação e de informações, para tornarem-se aptos e confiantes diante da sua realidade, pois estão permeados de necessidades emocionais, espirituais e físicas. Essa capacitação pode auxiliá-los a lidarem com suas dúvidas, preocupações (FONSECA; REBELO, 2011).

Além das dificuldades enfrentadas diante do cuidado na realização de procedimentos pelos familiares, soma-se a isso o convívio com a doença terminal, tornando o cuidado no processo de morrer uma missão permeada de devoção e despedida.

Mas é muito duro, muito duro, muito triste mesmo! Mas, a gente tem que se conformar, 
que a gente não pode fazer nada, a gente tem que, como eu disse aos meus irmãos: "olhe, a gente tem que mostrar o carinho que a gente sente por ele agora, a gente tem que deixar tudo o que a gente tem de fazer pra ficar perto dele agora, porque não adianta depois que ele tá no caixão, você dizer: Ah, o meu pai, o meu pai. Mostre a ele agora. (F2)

[...] tem que dar todos os cuidados pra que ela, pra que ela não esteja com dor, pra que não esteja sofrendo, mas, mesmo assim, é aquela sensação de perda. Não é assim que acontece? Quando eu estou com a minha vó, eu fico tentando não mostrar pra ela que eu estou triste, mas estou mal, muito mal (choro) e pra os meus meninos, tento ser forte o máximo que eu posso. Não sei até quando eu vou aguentar. (F5)

Desde que ela veio pra cá que eu fico aqui com ela[...] Tem hora que dá vontade de eu gritar, tem hora que dá vontade de eu falar, falar, falar. É, olho pra ela e peço: "Oh, meu Deus, me sustenta porque ela só tem a mim!" Porque as minhas irmãs, as minhas sobrinha vinha, mas ela não queria ficar com elas. (F6)

Aí, quando chegou aqui, que foi feita a tomografia, a médica explicou pra mim, pra gente, pra ser forte e a família ficar sempre do lado dela, aí que a gente ficou mesmo. ( F7)

Aí eu liguei pra minha outra irmã que mora no Jacintinho, aí ela veio e mais um monte de gente, que a família é grande. Aí numa hora dessas tem que se unir só não vem aqueles que não querem mesmo mais saber da família, mas [...].(F9)

Eu tirava meu tempo pra dar banho, que era pra não ficar infeccionada. Porque ela não abre muito a perna pra colocar a fralda. Eu 
dando banho, ajeitando, e ela sempre agressiva comigo. Mas eu ali, de dia e de noite, ali. [...] Ai, eu não sei, tem horas que eu não sei, essas pessoas assim de idade, falam tanta da coisa, às vezes, você sai fora do controle. Não sei... Porque, às vezes, ela reclama, e diz que é por que a gente quer matar ela. Aí eu digo que não, que a gente quer o bem dela, entendeu? Aí não sei, a gente fica cuidando direto, a pessoa não dorme direito, amanhece $o$ dia, é a noite todinha acordada. Tiro a roupa em casa, lavo a roupa suja. E o pior é que de uns dias pra cá, ela tá melhorando da disenteria, mas quando estava pior, o que batia dentro já tava saindo, isso era líquido, era tudo (choro). (F11)

Ele é meu pai, e eu amo muito o meu pai, mesmo a gente cuidando com tanto carinho a situação dele tá muito difícil mesmo. [...] Você tem de renunciar muitas coisas pra se dedicar só àquilo e principalmente você tem que ter amor no coração. Se você não tiver, você não consegue paciência, porque ele não tá mais com a memória boa, porque quando ele tava com a memória tava boa, ele se levantava e se lavava, agora ele não sabe mais o que faz, só quer estar sentado agora. Só que assim não tem circulação, ai os testículos dele estão inchando demais, ai tem que chamar a enfermeira pra me ajudar a convencer ele a se deitar [...]. (F12)

Sou sempre eu que estou acompanhando ele. Sempre! Direto! Não deixo ele só nunca, saio de manhã pra casa da minha prima e deixo uma pessoa com ele, às vezes o meu sobrinho. Nunca mais dormi pra não deixar ele sozinho parei de tomar remédio controlado, pra não dormir e não deixar ele sozinho. (F13)

O paciente em fase terminal necessita de cuidados extremos e necessários. Isso consequentemente demanda demasiado tempo 
de dedicação do familiar, sendo necessário que ele faça ajustes significativos na sua rotina familiar e adapte-se a essa nova rotina que inclui as exigências e demandas próprias do tratamento (INOCENTI; RODRIGUES; MIASSO, 2009).

Nesse movimento de cuidar do paciente terminal, é fundamental que o familiar reconheça a sua fragilidade perante o processo que vivencia e a necessidade de ser cuidado e de cuidarse.

Inocenti, Rodrigues e Miasso (2009) referem que os familiares requerem mais ajuda diante da iminência de morte do que o próprio paciente. Sentimentos de medo e impotência diante da doença são frequentes, em especial naquelas situações em que se percebem impotentes diante da dor e da condição da morte iminente.

O processo de morrer é difícil, e a família necessita do apoio de alguém, que não esteja envolto pelo mesmo sofrimento, com que possa dividir toda a angústia que está sentindo.

E hoje, a gente vê ele desesperado, pedindo ajuda de todo jeito, sabendo que ele não tem mais jeito, mas ele fica desesperado, fica pedindo, fica apelando que a gente faça as coisas pra ele. [...]. E a gente vendo que ele não pode andar, ele queria que a gente fizesse aquilo pra ele. Com ele tá sendo difícil pra gente, porque a gente nunca pensava que ele passaria por isso. (F2)

Neste dia, eu fiquei desorientada, assim, pensei que eu tinha que ser forte e cuidar da minha mãe. Mas eu estava sozinha aqui, ai eu comecei a chorar lá e ai eu vim pra aqui porque não da pra chorar lá. Não tinha aquela pessoa assim pra você ficar, como assim agora, tirar isto pra fora. Dai você fica mais conformada com uma pessoa conversando. [...] a família precisa muito de amparo das pessoas, às vezes de uma conversa como esta que eu estou tendo com você, às vezes desabafa. Com aquele modo que eu não posso falar com 
a minha mãe, não posso falar com uma pessoa que esta lidando com ele como a minha irmã, como eu posso falar com você. Não era pra ter uma pessoa como você, que escuta? A pessoa se sente muito melhor! Se não, o sofrimento é tão grande que acaba sufocando. [...] Você vê uma pessoa se acabando em quatro meses, $e$ você vendo que é uma coisa que não tem nada que você pudesse ter feito que animasse ele. Sempre foi já botando ele pra baixo, então a família toda esta muito abalada por causa disso.(F2)

Eu fico mal porque com a distância que tem da minha idade para a dele, eu tenho um sentimento de esposa e de filha. Eu me sinto como uma pessoa totalmente necessitada de ajuda, ter com quem conversar. A minha filha também precisa de ajuda, já tentei conversar com minha filha, mas ela não quer conversar. Minha irmã já sugeriu levar ela pra um psicólogo. [...] Muitas vezes sentimos algo e não sabemos expressar, a dor é grande, mas não sei colocar para fora. (F4)

E eu fico pedindo força, força pra eu conseguir, porque se eu desistir, não aguentar, tem minha mãe em casa, já tá muito aperreada, meu pai, é muito difícil, muito ruim. É cansativo estar aqui, mas é aquele cansativo assim (choro).(F6)

Quando eu estava desesperada, queria mais um buraco para me esconder e ficar lá. Aí, a menina conversou comigo. (F7)

Nesse tempo que eu estou aqui ninguém chega pra me ajudar, conversar comigo, saber se tô bem. (F11)

E pra você que nunca passou por uma situação dessas fica difícil, tem horas que eu choro, porque assim, porque ele não me entende e fica difícil de eu entender ele assim. Eu quero 
que ele me entenda, mas ele não ta mais entendendo, é muito difícil mesmo.[...] Ele esta chegando num estagio muito difícil mesmo e fica difícil mesmo. E fica difícil pra gente que esta acompanhando porque meche muito com a gente por mais que você esteja alertado, que você receba aquelas noticias. (F12)

E, aí ultimamente eu tenho tido crises de choro, daí a psicóloga veio conversar comigo só que eu já tô de um jeito agora que eu não tô suportando mais estar aqui dentro, estou vindo pelo meu pai, mas eu já cheguei ao meu limite, só que, ao mesmo tempo, eu tenho de ficar ao lado dele. (F15)

O existir solícito é uma característica existencial do homem em seu sendo-no-mundo, escutar e olhar atentamente configura-se em um instrumento necessário para aprender a compreender os pacientes e seus familiares em sua totalidade e singularidade, sendo fundamental entrar no mundo do outro, ver, por meio dos seus olhos e escutar com envolvimento sobre suas angústias em relação as experiências vividas (SALES et al., 2012).

O tratamento do paciente terminal influencia não somente o paciente com também a família, que constitui uma peça fundamental na fase final da doença e esta exposto aos mais variados tipos de sentimentos como o medo, a angústia e impotência diante da proximidade de morte do seu familiar em processo de morrer, o qual direciona cuidados, portanto torna-se importante que receba cuidados da equipe profissional (INOCENTI; RODRIGUES; MIASSO, 2009). Para Jardim et al. (2011), o apoio articulado disponibilizado para o familiar que vivencia o processo de morrer possibilitara ao familiar auxiliar o paciente em fase terminal na sua transcendência.

Promover o cuidado, preocupando-se com o lado emocional, é atuar incondicionalmente em beneficio da melhoria da qualidade de vida do paciente em fase terminal e de sua família, preparando-os 
para acompanhar e suportar a dor e a angústia e resgatar a vida num contexto de morte (SANTANA, 2008).

Pelos depoimentos, foi observado que os familiares buscaram fortalecimento e segurança no suporte espiritual, para o enfrentamento desse processo, a busca pela religiosidade institui forças para ajudá-los a vencer as dificuldades, amenizando o sofrimento e dando conforto.

[...] primeiramente vem Deus, abaixo de Deus vem os médicos que procuram ajudar e a assistente social também. Todos que procuram ajudar e a família, que todos estamos aqui. Deus primeiramente, abaixo de Deus ele vai dando a mão aos médicos e os médicos vão controlando. E Deus vai curar ele! Quando o médico chegou pra falar com a gente sobre o estado dele, eu particularmente me senti muito abatida. Mas Deus me conformou, sabe? (F9)

Eu sei que eu tô no meu limite, mas sempre vem aquela força que eu peço a Deus. Eu sou católica, assim, mas não tive mais tempo nenhum de ir na igreja que as vezes quando chega noite eu já tô tão cansada que nem falo. (F15)

Tanto é que você vê a situação do meu pai, eles queriam que ele fosse pra casa, do mesmo jeito. Agora, pense no sofrimento da família, a família fica desesperada sem saber. O meu pai, no dia em que ele se internou aqui, a gente não achava que ele ia amanhecer vivo, todo mundo rezando pra chegar de manha pra gente vir com ele pra cá. (F2)

Agora a gente tá indo pra igreja, fazendo corrente. Eu conversei com ela, disse que fizesse um voto com Deus pra sair dali. Que só ela quem pode falar com Deus, [...]. (F3) 
A espiritualidade, manifestada através da crença em Deus, nos discursos acima referidos, consistem em um meio de consolo que os familiares encontraram e uma motivação para acreditarem que as coisas vão resolver-se da melhor forma.

Para Inocenti, Rodrigues e Miasso (2009), diante do processo de morrer, a fé é um sentimento tão necessário quanto qualquer outra estratégia de enfrentamento. Diante das situações de angústia e sofrimento, a religiosidade ajuda a obter forças externas para superação, permitindo ao familiar sentir-se cuidado por uma proteção superior. Sapadacio e Barros (2009) corroboram que a religiosidade torna-se um meio facilitador para o enfrentamento da doença e da morte.

Os familiares projetam em Deus uma força superior que dará o conforto necessário para esse processo de morre. Assim, a espiritualidade é um dos aspectos marcantes diante da doença terminal, independente da crença religiosa, proporciona conforto e confiança para a família, a fé mantém a esperança de uma recuperação, tornando-se, assim, um refúgio, uma segurança (MENDES, 2013).

Assim, apesar de toda a dor sentida durante o processo de morrer, compreende-se que 0 cuidado apresentou-se como fundamental na experiência vivida pelos familiares, possibilitando uma redução do sofrimento, quando se dão conta de que permaneceram, presentes ao lado do familiar, resgatando o cuidado autêntico durante os tempos difíceis.

\section{Ser-aí no mundo do hospital}

Considerando que ser-aí é um ser lançado no mundo para existir, assim o familiar do paciente em processo de morrer é um ser lançado no mundo do hospital que vivencia, de forma velada ou explícita, os aspectos mais profundos da existência humana e revela os significados que atribui à vida, de forma consciente ou 
inconsciente, ao desenvolver o cuidado com o seu familiar em fase terminal de vida.

No mundo do hospital, a família tem ocupado um espaço importante, e a equipe de saúde gradativamente tende a reconhecer sua importância para a assistência ao paciente em processo de morrer, pois sua presença institui segurança para o paciente em fase terminal de vida, para a equipe de saúde que presta cuidados a ele e inclusive para o próprio familiar.

O primeiro vínculo com o mundo do hospital foi estabelecido com a descoberta da doença:

Eu corria aqui com ela pra o CACON, atrás de tratamento, não tem como não vir, aí eles botavam ela no soro. E assim foram esses meses todinhos, neste corre, corre, por causa desse tumor. Os familiares sofrem porque possuem consciência da dimensão do sofrimento e das privações do seu familiar doente. (F11)

Inserido no novo contexto, o familiar necessita de que a equipe disponibilize compreensão, apoio e ajuda para enfrentar as dificuldades inerentes ao cotidiano do mundo do hospital.

Os familiares sentem a ausência dessa interação de forma impactante:

Aí, a gente vinha, falava com um, falava com outro, que diziam "Olha, só a médica dele, só ela que vai dar a definição". (F2)

Por meio das verbalizações dos familiares, constata-se que a equipe que prestava cuidados com o seu familiar, não oferecia as informações necessárias sobre o diagnóstico e o prognóstico da doença.

Diante de um diagnóstico de terminalidade de vida, faz-se necessária uma conversa clara e estruturada, envolvendo o doente e a família, sendo direcionada e apoiada pelos profissionais envolvidos com o cuidado direto ao paciente. Esses profissionais devem 
apresentar disponibilidade para ouvir, pois um período de complexas decisões far-se-ão presentes, quando serão tomadas decisões e escolhas, sobre o tratamento, bem como referentes ao estado psicológico, espiritual, interpessoal e questões práticas associadas à morte daqueles envolvidos (WENRICH et al., 2001). Pereira e Dias (2007) corroboram a respeito da importância da eficácia da comunicação existir entre os familiares e o paciente em processo de morrer, referindo que, embora difícil, torna-se necessária.

Também foi observado pelos depoimentos, que os profissionais de saúde não informavam sobre a justificativa dos sintomas clínicos que seu familiar apresentava, deixando-os insipientes:

Agora ele não está mais conversando e nem falando. Ontem ele ainda conversou até às 22 horas, aí depois ele dormiu. Porque ontem ele ficou diferente, e eu fiquei preocupada. A moça veio, olhou e foi embora, e eu preocupada, já imaginando que ele ia morrer ali mesmo, me levantei fiquei de pé e disse: - Agora eu vou procurar os médicos! Porque ele estava todo frio e suado. (F13)

Desde ontem, aliás, desde anteontem, que eu falei pra médica que a minha irmã, tá piorando, o quadro dela tá piorando, ela tá pior! Ela foi, olhou e ficou calada [...]. (F6)

Por não compartilharem as informações com os familiares, os profissionais estão impossibilitando que o familiar vivencie o processo de forma participativa.

Frequentemente, o familiar, quando presente no mundo do hospital, não é compreendido pela equipe como facilitador de cuidado, sendo excluído, desrespeitado e não inserido como elemento participante e corresponsável no processo de tratamento (FARIA; PEREIRA, 2007). 
O não compartilhamento das condutas e condições de tratamento podem propiciar ao familiar a não aceitação do processo de morrer do paciente.

Desse modo, manter a família acolhida e esclarecida é importante para a tomada de decisão, o que a torna muito mais legítima para o enfrentamento do dilema (CHAVES; MASSAROLLO, 2009).

Conforme observado nos relatos, o acolhimento acontece de forma imparcial pela equipe de saúde, consequentemente os familiares sofrem um forte impacto quando são informados sobre o diagnóstico da doença com mal prognóstico, assim a notícia da impossibilidade da cura chega de forma cruel e traumatizante.

A médica vai falar com vocês [...]. Ela disse:
"Não se engane não, porque o quadro dela é
daí pra pior". Disse exatamente isso: "Não se
engane não, o quadro dela é daí pra pior. Você
sabe que ela está num último estágio da
doença. Ela está no estado terminal." E a gente
não sabia, quer dizer a médica dela falou pra o
meu esposo quando internou, ela disse que ia
deixar ela na UTI, quando ela estivesse mais
estável é que ia levar ela pra enfermaria,
avaliar o estado dela e se possível continuar o
tratamento, ela falou assim. E ela veio dizer
isso: "Não, não se engane não. Não estou aqui
par enganar ninguém não. Ela, é dali pra pior,
você não vai ver melhora nela". Tão fria! Às
vezes é porque [...] tudo bem que tem casos
que é uma realidade, mas eu acho que toda
realidade tem uma maneira de se falar, não é?
[...]. (F1)

Os familiares que agora se encontram lançados no mundo do hospital, vivenciando de forma intensa a finitude humana, conscientizam-se do consequente início da fase terminal, que acarretará uma série de dificuldades permeadas pela dor e pelo sofrimento. Os enfrentamentos dessas dificuldades pelos familiares 
vão depender de estratégias fortemente influenciadas pela forma de cada um lidar com a morte:

Aí, quando chegou aqui, que foi feita a tomografia, a médica explicou pra mim, pra gente, pra ser forte, e a família ficar sempre do lado dela. Aí que a gente ficou mesmo. Mas aí, quando ela disse isso, veio logo aquela reação pra mim, naquele momento de saber que era assim. (F7)

Agora você me pergunta: é difícil pra mim? É, porque eu lutar tanto, pedir tanto [...], e o médico chegar pra você e dizer assim: "É terminal! Não dá mais tempo de fazer quimioterapia, não tem remédio, não tem nada!". (F14)

Mas, a certeza mesmo a gente só teve quando a médica disse que não ia poder fazer mais nada, que ele ia viver agora uma vida só pra ele ter conforto, que agora não dependia mais de médico. Só, talvez, de um milagre de Deus. Pra Deus nada é difícil! (F2)

$\mathrm{Na}$ segunda-feira da semana passada, a médica me falou por alto; que ela fez a tomografia e deixou por alto que não tinha solução. Aí, ontem, minha mãe apareceu aqui no hospital, e a médica já pediu pra avisar totalmente à família, funerária, qualquer coisa pra não deixar em mão. Fica difícil, ela já tem oitenta e poucos anos. (F5)

Ai, quando foi hoje, ela foi e falou que eu tinha razão, que ela ainda não tinha falado nada, mas o quadro dela estava piorando e pediu que eu avisasse toda família que a qualquer momento [...]. Dai eu falei: -Tá bom, tem de ser, né? Às vezes a gente não entende? Só Deus! O jeito é pedir força pra Ele. Mas que é horrível é! (F6) 
Diante da experiência da finitude, é de suma importância que a comunicação interpessoal seja facilitadora da interação com os familiares, devendo transmitir atenção, compaixão e conforto. Independente da área de formação básica do profissional, faz-se necessário usar estratégias corretas para expressar suas ideias, clarificar e validar informações (ARAÚJO; SILVA, 2012).

Heidegger afirma que, na cotidianidade das relações, a qualidade de poder ser tocado por aquilo que the vem ao encontro no mundo refere-se fundamentalmente à disposição que revele o mundo a partir das diversas formas.

Nos relatos dos familiares entrevistados, o prognóstico da terminalidade parece vir ao encontro, dando-Ihes a dimensão de serem atingidos, fundando-se, assim, na disposição da ameaça, reconhecida que tem seu familiar como alvo. Destarte, o que se teme não está na morte, mas na relação que será estabelecida diante da presença da sua ameaça.

A reação da família é muito intensa diante o processo de morrer. Heidegger (2011) afirma que a possibilidade da finitude, embora a morte faça parte da existência, e de difícil aceitação.

A experiência do processo de morrer desvela-se no familiar de forma vigorosa à sensibilidade, à preocupação, à angústia e ao medo, sendo observada também a manifestação da solicitude entre as famílias no cotidiano do hospital.

[...] eu trabalhava neste andar, eu sei que aqui a maioria é neste estado. Eu sei do sofrimento da família, eu sei o sofrimento de todo mundo. $E$, quando eu vi meu pai aqui, eu já me imaginei. Às vezes, as pessoas dizem que eu estou sofrendo antecipado, eu digo não, porque eu vejo, eu vejo como é, entendeu? Eu sei que a gente só sabe como é, quando a gente passa. (F2)

Teve o seu Rafael que morreu esse mês de fevereiro, que a esposa dele estava conversando comigo, aí ele começou a cansar, 
cansar, cansar. Daí ela mandou eu segurar na mão dele pra correr e pedir ajuda, foi aí quando ele morreu. Assim, eu pensei que ele tinha desmaiado. Eu fiquei tão impressionada que à noite não consegui dormir. [...] Já morreu tanta gente no mundo, nesse lugar que o meu pai está, já teve até um homem que já foi meu vizinho numa chácara que eu tinha lá em Fernão Velho, também já morreu, chegou a morrer três numa semana. Isso é muito impressionante pra mim. (F15)

Esses sentimentos presentes no mundo do hospital são compartilhados pelas famílias que vivenciam o mesmo processo existencial. Essa relação que tem como base o sentimento de solicitude.

O mundo do hospital remete a uma realidade dolorosa, difícil e angustiante que o familiar obriga-se a enfrentar, sofrendo um impacto capaz de desestruturá-lo.

Então, você está na tua casa e já vem para o hospital, já não é uma coisa muito fácil pra pessoa. Principalmente eu que vim pra o hospital nesta fase, acompanhar minha avó, que é uma pessoa muito próxima e que você sabe que está ali em um processo final [...]. (F5)

Porque eu não aguento passar todos os dias e é muito cansativo por ser um hospital. A gente acaba vendo os outros pacientes também, e fica meio abalado. (F7)

Quando eu entro na UTI, eu me sinto triste, só em estar aqui, eu já venho com o coração apertado. E saio e fico em casa só pensando, pensando, pensando, esperando, só esperando alguma coisa acontecer, tipo ela morrer, porque a pessoa só espera isso, no estado que ela esta, do jeito que ela esta, só consigo pensar e esperar isso. (F8) 
[...] dentro o hospital se é difícil pro doente pra você também é porque você é responsável, você renunciou uma vida lá fora praticamente. (F12)

No pensamento heideggeriano, o sentimento de situação ou angústia é um aspecto fundamental do ser-aí e emerge do discurso do familiar de forma consciente ou inconsciente. Esse sentimento é a tomada de consciência do familiar de sua situação indefinida, de sua desproteção e desamparo, lançado ao mundo independente de sua vontade.

Ao ser lançado no mundo, consciente do que é o melhor para o seu familiar, assume esse fato existencial e passa a viver autenticamente, readaptando-se e buscando alternativas para conviver com a dura realidade.

Você aqui tem que aprender a conviver dentro do hospital com a comida, com tudo, pelo menos aqui no $\mathrm{HU}$, tem um cantinho só pra ele, lá [...] não era assim, aí, às vezes, ele ficava mais agitado, aí é melhor aqui. (F12)

A estrutura, a organização e a dinâmica do contexto hospitalar estão voltadas para a manutenção da vida, assim o mundo do hospital é visto como provedor de conforto para o paciente que está em fase terminal de vida.

[...] Se você perguntar se ele quer ir pra casa, ele diz logo: "Não, aqui eu tenho tudo, aqui eu como tudo, aqui o que puderem fazer por mim, vão fazer". [...] Aqui no hospital, ele se sente mais amparado, a gente falou com a médica dele, que queria dar alta pra ele hoje, ele me disse que não queria ir pra casa, que ele sabia que lá não ia ter condições... Aqui no hospital ele está bem tratado! [...] Ele sabe que em casa não é assim. E, agora, depois que ele veio pra aqui, que em casa ele estava sofrendo muito, $e$ a gente não estava tendo condições de colocar ele aqui, os médicos diziam "a gente não bota a mão, só o médico dele”. Mas o médico dele 
preferia que ele terminasse o resto da vida dele em casa. Mas o sofrimento dele estava muito grande. Tanto é que, se hoje você chegar lá e perguntar a ele: Você quer ir pra casa? Ele não quer, porque ele aqui está bem. (F2)

Está bem pesado pra mim. E ele dizia pra eu levar ele pra casa, pra eu pode ir dormir em casa também. Aí, eu dizia que se ele dormisse em casa, ele ia abrir mão da melhora pra ele mesmo, porque no hospital ele toma remédio, $e$ em casa? (F13)

A relação da família no mundo do hospital desvela dimensões existenciais do estar-com-o-outro no mundo. Entretanto esse é um mundo diferente e um mundo do ser doente que necessita de cuidado:

Ele ficar direto aqui é sofrido. Teve uma médica que me orientou a procurar o Ministério Público pra conseguir o Home Care e tiveram pessoas que disseram que eu ia sofrer mais, porque a pessoa que cuida, às vezes, sofre mais que $o$ paciente, mas eu ia ter o prazer de cuidar dele. Acho que eu ia me sentir melhor com ele em casa, mas não podemos pensar somente em nós, teria que ver as condições dele, se ele ia suportar, pois ele ficar totalmente dependente, como as pessoas dizem, ele ia ficar vegetando (choro). (F4)

Neste mundo, a família constitui-se como apoio para o seu familiar doente, quando se percebe envolta pela dependência instalada diante da gravidade do estado de saúde do seu familiar internado. Ela adapta-se, a fim de suprir essas necessidades (MILIORINI et al., 2008).

Ao assumir o cuidado do seu familiar, propõe-se a acompanhá-lo até o final de sua trajetória existencial. Oferece o seu afeto e apoio, cumprindo com o seu papel de ser-no-mundo, vivendo 
autenticamente, enfrentando a angústia de ser lançado no mundo com a dor de ter um familiar em fase final de vida.

[...] eu não sei nos outros lugares, quando o paciente está assim no estágio como o do meu pai, como tem outros aí também, que estão quase igual ao do meu pai, a família fica até o último minuto. Eles ficam até quando eles perdem o sentido, mas antigamente, você ia pra uma UTI, [...] hoje em dia aqui a gente não vê isso. Eles isolam, mas não tiram do quarto, ali você pode ver a família, vem uma pessoa distante que quer ver ele ainda com vida, pode ver, e na UTI não pode, nem todo mundo pode entrar. Aqui, o que eu acho bom é o acesso pra família fica perto, é bom, é doloroso, que a gente não quer ver uma pessoa morrendo na frente da gente, mas pelo menos você tá perto. (F2)

Outro aspecto que emerge dos conteúdos vivenciais é do internamento do paciente na UTI, remetendo ao familiar a percepção de que todo paciente que vai para esse setor é porque está em iminência de morte.

Mas agora na UTI é como se já fosse, já fosse preparando a gente pra morte dela. Mas, mesmo assim, a pessoa acaba não aceitando. (F8)

O fato de seu familiar estar internado na UTI, para alguns, já é indício de morte, considerando que esse setor carrega o mito de ser um lugar para a morte (COMASSETTO; ENDERS, 2009).

Nesse mundo da UTI, os familiares sentem-se roubados da oportunidade de acompanhar junto ao seu familiar os momentos que ainda Ihe restam:

Os médicos estão dizendo que não tem mais cura, então seria muito bom, bem melhor, que a gente pudesse ficar mais próximo dela. Assim, porque seria melhor que, nos últimos 
dias, os últimos momentos, a gente pudesse estar perto, é isso. (F10)

Acompanho tudo e venho todos os dias na visita. [...] Eu entrei de férias pra ficar com ela na enfermaria né, ai ela já veio direto pra UTI, ai o único contato que a gente tem com ela é na visita. [...]. (F8)

Os familiares de pacientes internados nesse setor sofrem com o sentimento de angústia, por serem proibidos de permanecer juntos diante de um momento em que estão fragilizados emocionalmente, $\mathrm{e}$ o apoio mútuo seria traria consolo (COMASSETTO; ENDERS, 2009).

Dessa forma, Hennezel e Leloup (2009) afirmam que os hospitais não estão preparados para cuidar, acolher e acompanhar os envolvidos no processo de morrer, seja ele o paciente, ou o familiar. A fim de melhorar a assistência hospitalar aos pacientes em fase final de vida, Fridh, Forsberg e Bergbom (2007) consideram necessário investir na melhoria do ambiente, promovendo a privacidade e a proximidade do paciente com o seu familiar.

A finitude é uma realidade vivida pela família, e a morte é uma realidade de todo ser-no-mundo. Entretanto experienciar essa realidade existencial é doloroso e difícil, principalmente, quando inserido em um mundo onde o limite entre a vida e a morte é tão estreito. 


\section{CONSIDERACÕES FINAIS}

A minha trajetória na busca para compreender a experiência do familiar de pacientes em fase terminal de vida, que enfrentam o processo de morrer no mundo do hospital, deveu-se à minha inquietação diante da vivência dos familiares, no decorrer da minha vida profissional, relativa à possibilidade da perda.

A escolha pelo referencial da fenomenologia propiciou-me apreender algumas facetas que surgiram durante a realização deste estudo, que não seriam possíveis com outro referencial. Com o apoio no referencial filosófico de Martin Heidegger, realizei a análise e a interpretação das vivências que os familiares externaram através dos seus discursos e, com isso, elucidou-se o que se mostrava oculto aos meus olhos.

Reconheço e revelo que me senti fragilizada ante o manifesto nas narrações, permeadas de emoções do vivido pelos familiares que, acima de tudo, eram mães, filhas, esposas, ou que mantinham outro grau de parentesco, enriquecido pela condição de afinidade com o paciente que estava em processo de morrer. Entretanto o desejo de compreender suas experiências constituiu-se em um incentivo que impulsionou o meu caminhar ao encontro da possibilidade de desvelar o que eu desconhecia.

Acredito ter desvelado os significados que o familiar experienciador dessa vivência atribuía ao fenômeno, que se torna inesgotável, permitindo a outro ser vê-lo "com outros olhos". Entretanto não é fato que, ao ser analisado em outro contexto, o fenômeno desvelar-se-á semelhante, mas, sim, que os resultados obtidos neste estudo poderão enriquecer a sua compreensão.

Apreendi a dimensão do sofrimento que o familiar enfrenta, quando imposto à condição de estar-no-mundo, vivenciando o processo de morrer do seu familiar em fase final de vida, quando a possibilidade da terminalidade fez-se presente na vida da família, ocasionando um caminhar para a concretude, permeado de 
inúmeros sentimentos complexos, intensos e difíceis de serem superados. O familiar tem a possibilidade de encontrar a sua autenticidade e começa a enxergar a existência humana com "uma outra lente".

Os sentimentos expressos remeteram a pensar que o familiar despertou para o seu existir-no-mundo, percebendo a importância do cuidado e da solicitude. Doa-se para ofertar o cuidado ao seu ente querido, mas também se manifesta como dependente e carente do cuidado, que, muitas vezes, não recebe, principalmente dos profissionais da saúde com quem convive no mundo do hospital, local onde o limite entre a vida e a morte é tão estreito, tornando-se um lugar desagradável, porém provedor de conforto para o momento de fragilidade que seu familiar está passando.

Ficou evidente que se veja o familiar como um sujeito aliado ao tratamento do paciente e como um ser merecedor de assistência. Faz-se necessária a inserção do familiar na promoção de ações de acolhimento e cuidados específicos frente às necessidades individuais de cada familiar. Essas ações devem ser ofertadas por profissionais de saúde capacitados, portanto, torna-se relevante que o tema "morte" seja inserido na formação dos profissionais de saúde, sinalizando a importância da reflexão dessa temática, para desenvolver uma assistência que seja compatível com a situação vivenciada pelos familiares diante da terminalidade.

Vale ressaltar a satisfação de ver o fenômeno que este estudo propôs revelar, tornar-se claro, possibilitando um maior conhecimento para uma melhor compreensão por parte dos enfermeiros e demais profissionais da equipe de saúde frente à assistência ao familiar, compatível com a necessidade deste, visando ao bem-estar tanto do familiar em questão, quanto do paciente inserido nesse contexto. 


\section{REFERÊNCIAS}

AGRA, L.M.C.; ALBUQUERQUE, L.H.M. Tanatologia: uma reflexão sobre a morte e o morrer. Pesquisa Psicológica, Maceió, ano 1, n. 2 , jan. de 2008.

ALENCAR S.C.S.; LACERDA M.R.; CENTA, M.L. Finitude Humana e Enfermagem: reflexões sobre 0 (des) cuidado integral e humanizado ao paciente e seus familiares durante o processo de morrer. Família Saúde e Desenvolvimento, vol. 7., n. 2, p. 171-180, Curitiba. 2005.

ALVES, P.C. A fenomenologia e as abordagens sistêmicas nos estudos sócio-antropológicos da doença: breve revisão crítica. Cadernos de Saúde Pública, Rio de Janeiro, vol. 22, n. 8, p. 15471554, 2006.

ÂNGELO, M. Com a família em tempos difíceis: uma perspectiva de enfermagem. 1997. Tese (livre docência) - Escola de Enfermagem da USP, Universidade de São Paulo. 1997.

ÂNGELO, M. Família como categoria de análise e campo de investigação em enfermagem. Revista da Escola de Enfermagem da USP, vol. 43, p.1337-1341, 2009.

ANGERAMI, V.A. Psicoterapia Existencial, 4. ed, São Paulo: Thomson Learning Brasil, 2007.

ARAÚJO M.M.T.; SILVA M.J.P.A. Estratégias de comunicação utilizadas por profissionais de saúde na atenção à pacientes sob cuidados paliativos. Revista da Escola de Enfermagem da USP, vol. 46, n. 3, p. 626-632. 2012.

ARAÚJO, P.A. Nada, angustia e morte em ser e tempo, de Martin Heidegger. Revista Ética e filosofia politica, vol. 10, n. 2, 2007.

ARIÈS, P. História da morte no ocidente: da idade média aos nossos dias. Rio de Janeiro: ALVES, F., 2003.

BECKSTRAND, R.L.; CALLISTER, L.C.; KIRCHHOFF, K.T. Providing a "Good Death": Critical Care Nurses' suggestions for Improving end-of-life care. American Journal Of Critical Care, vol. 15, n. 1, January, 2006.

BELLO, S.S.; VERGARA, V.P.; O'RYAN, S.L.; ALFARO, B.A.M.; ESPINOSA, S.A. Estudio de las percepciones y actitudes del personal de una unidad hospitalaria frente a enfermos terminales. Revista chilena de enfermedades respiratorias. vol. 25, n. 2, p. 91-98. Santiago jun. 2009. 
BERTOLDO, C.; GIRARDON-PERLINI, N.M.O. A trajetória de uma família no adoecimento e morte de um familiar por câncer: Compromisso e solidariedade Revista contexto \& saúde, ljuí, Unijuí, vol. 6, n. 12, p. 49-58, jan/jun 2007.

BICUDO, M.A.V. Sobre a fenomenologia. In: BICUDO, M.A.V.; ESPÓSITO, V.H.C. Pesquisa qualitativa em educação: um enfoque fenomenológico. Piracicaba: Unimep, 1994.

BITENCOURT, A.G.V; NEVES, F.B.C.S.; DURÃES, L.; NASCIMENTO, D.T.; NEVES, N.M.B.C.; TORREÃO, L.A.; AGARENO, S. Avaliação do Conhecimento de Estudantes de Medicina sobre Morte Encefálica. Revista Brasileira de Terapia Intensiva, vol. 19, n. 2, p.144-150, 2007.

BORGES, MS; MENDES, N. Representações de profissionais de saúde sobre a morte e o processo de morrer. Revista Brasileira de Enfermagem, Brasília, vol. 65, n. 2, p. 324-331, mar./abr. 2012.

BOUSSO, R.S. Um tempo para chorar: a família dando sentido à morte prematura do filho. 2006. Tese (livre-docência) - Escola de Enfermagem da Universidade de São Paulo, São Paulo. 2006.

BRYSIEWICZ, P. The lived experience of losing a loved one to a sudden death in KwaZulu-Natal. Journal of Clinical Nursing, vol. 17, p. 224-231, 2008.

CAPALBO, C. Considerações sobre o método fenomenológico e a enfermagem. Revista Enfermagem UERJ, Rio de Janeiro, vol. 2, n. 2, p. 192-97, out. 1994.

CARVALHO, M.V.B. O cuidar no processo de morrer na percepção das mulheres com câncer: uma atitude fenomenológica. Tese de Doutorado - Escola de enfermagem da Universidade de São Paulo, 179 p., São Paulo, 2003.

CESTARI, M.E.W. Estar infectada com Papilovirus Humano: vivências das mulheres e necessidades de cuidados. Tese de Doutorado, Escola de Enfermagem da Universidade de São Paulo. São Paulo, 2010.

CHAVES, A.A.B.; MASSAROLLO, M.C.K.B. Percepção de enfermeiros sobre dilemas éticos relacionados a pacientes terminais em Unidades de Terapia Intensiva. Revista da Escola de Enfermagem da USP, São Paulo, vol. 43, n. 1, Mar. 2009.

COMASSETTO I; ENDERS B.C. Fenômeno vivido por familiares de pacientes internados em Unidade de Terapia Intensiva. Revista Gaúcha Enfermagem, vol. 30, n. 1, p. 46-53, Porto Alegre, mar. 2009. 
DARTIGUES, A. O que é a Fenomenologia? 3 ed., 174 p. Editora Moraes, São Paulo, 1992.

DOWNEY, L.; ENGELBERG, R.A.; CURTIS, J.R.; LAFFERTY, W.E.; PATRICK, D.L. Shared priorities for the end-of-life period. Journal of Pain and Symptom Management, vol. 37, n. 2, p. 175-188, 2009.

DRIESSNACK M.; SOUSA V.D.; MENDES, I.A.C. Revisão dos desenhos da pesquisa relevantes para a enfermagem: parte 2: desenhos da pesquisa qualitativa. Revista Latino-americana Enfermagem, vol. 15, n. 4, julho-agosto 2007.

DUARTE R.; NAVES G. O ser-para-a-more em Heidegger. Revista Católica, v. 2, n. 4, p. 64-82, Uberlândia. jul/dez. 2010.

DUARTE, M.R; ROCHA, S.S. As contribuições da filosofia heideggeriana nas pesquisas sobre o cuidado em enfermagem. Cogitare Enfermagem, Abr/Jun 2011.

DUBOIS C. Heidegger: introdução a uma leitura. Rio de Janeiro: Zahar. 248 p. 2004.

DURÁN G.A.; GARANHANI M.L.; BORTOLETTO M.S.S.; ALMEIDA M.J., REGINA M.; ALMEIDA N.E.F.P. Fenomenologia heideggeriana como referencial de para estudos sobre formação em saúde. Interface - Comunicação, Saúde, Educação (Botucatu) vol.16, n. 42, p. 809-817, Set. 2012.

EDNAMARE, O.S.; SUDIGURSKY, D. Concepções sobre cuidados paliativos: revisão bibliográfica. Acta Paulista de Enfermagem. vol. 21, n. 3, São Paulo, 2008.

FARIA M.D.; PEREIRA M.S. Cuidados paliativos - O olhar do enfermeiro na assistência aos familiares de clientes fora de possibilidades terapêuticas. WebArtigos. 2007. Citado em 24 Mar 2013. Disponível em:

http://www.webartigos.com/articles/2832/1/cuidados-paliativos-oolhar-do-enfermeiro-na-assistencia-aos-familiares-de-clientes-forade-possibilidades-terapeutica/pagina1.html

FONSECA J.V.C.; REBELO T. Necessidades de cuidados de enfermagem do cuidador da pessoa sob cuidados paliativos. Revista Brasileira de Enfermagem. vol. 54, n. 1, p. 180-186, 2011.

FREIRE, M.C.B. O som do silêncio: isolamento e sociabilidade no trabalho de luto. Natal: Edufrn, 2006.

FRIDH, I.; FORSBERG, A.; BERGBOM, I. Family presence and environmental factors at the time of a patient's death in an ICU. Acta 
Anaesthesiologica Scandinavica, vol. 51, n. 4 , p. 395-401, abril 2007.

GIGLIO, A.D. O preparo do médico e a comunicação com familiares sobre a morte. Revista da Associação Medica Brasileira, São Paulo, vol. 51, n. 1, Fev. 2005.

GOMES, A.M.R. O cuidador e o doente em de fim de vida - família e/ou pessoa significativa, Enfermería Global, n. 18, Fev. 2010.

GUINART, Z.N. Cómo atender a la familia del enfermo terminal. Revista Cubana de Medicina General Integral, vol. 22, n. 1, 2006.

GUTIERREZ, P.L. Ó Que é O Paciente terminal? . Revista da Associação Médica Brasileira, vol. 47, n. 2, p. 92-92. 2001.

HAWKER, S.; KERR, C.; PAYNE, S.; SEAMARK, D.; DAVIS, C.; ROBERTS, H.; JARRETT, N.; RODERICK, P.; SMITH, H. End-of-life care in community hospitals: the perceptions of bereaved family members. Palliative Medicine, vol. 20, n. 5, p. 541-547, Jul. 2006.

HEBERT, R.S.; SCHULZ, R.; COPELAND, V.C.; ARNOLD, R.M. Preparing Family Caregivers for Death and Bereavement. Insights from Caregivers of Terminally III Patients. Journal of Pain and Symptom Management, vol. 37, n. 1, Jan. 2009.

HEIDEGGER, M. Ser e Tempo, Petrópolis - RJ, $5^{\text {a }}$ edição, Edit. VOZES e Edit. Universitária, São Francisco, 2011.

HENNEZEL, M.; LELOUP, J.Y. A arte de morrer: tradições religiosas e espiritualidade humanística diante da morte na atualidade. 10 ed., Edt. Vozes, Petrópolis, RJ, 2009.

HEYLAND, D.K.; DODEK, P.; ROCKER, G.; GROLL, D.; GAFNI, A.; PICHORA, D.; SHORTT, S.; TRANMER, J.; LAZAR, N.; KUTSOGIANNIS, J.; LAM, M. What matters most in end-of-life care: perceptions of seriously ill patients and their family members. Canadian Medical Association Journal, vol. 174, n. 5, Feb. 2006.

INABA, L.C.; SILVA, M.J.P.; TELLES, S.C.R. Paciente crítico e comunicação: visão de familiares sobre sua adequação pela equipe de enfermagem. Revista da Escola de Enfermagem da USP, vol. 39, n. 4, p. 423-429, 2005.

INOCENTI, A.; RODRIGUES, I.G.; MIASSO, A.I. Vivências e Sentimentos do cuidador familiar do paciente oncológico em cuidados paliativos. Revista Eletronica de Enfermagem. vol. 11, n. 4, p. 858-65, 2009.

INWOOD M. Dicionário Heidegger. Tradução Luisa Buarque de Holanda. Rio de Janeiro: Zahar, 2002. 
JARDIM D.M.B.; BERNARDES R.M.; CAMPOS A.C.V.; PIMENTA G.S.; RESENDE F.A.R.; BORGES C.M. et al. O cuidar de pacientes terminais: experiência de acadêmicos de enfermagem durante estágio curricular. Revista Baiana de Saúde Pública, vol. 34, n. 4, p. 796, 2011.

JOSGRILBERG, R.S. O método fenomenológico e as ciências humanas. In: CASTRO, D.S.P. et al. Fenomenologia e análise do existir. Universidade Metodista de São Paulo: Sobraphe, p. 75-93, São Paulo, 2000.

KING, N.; BELL, D.; THOMAS, K. Family carers' experiences of outof-hours community palliative care: a qualitative study. In International Journal of Palliative Nursing, vol. 10, n. 2, p. 76-83, Feb. 2004.

KIRCHHOFF, K.T.; WALKER, L.; HUTTON, A.; SPUHLER, V.; COLE, B.V.; TERRY, C. The Vortex: Families' Experiences With Death in the Intensive Care Unit. American Journal of Critical Care, vol. 11, p. 200-209, 2002.

KNOBEL, E.; ANDREOLI, P.B.A.; ERLICHMAN, M.R. Psicologia e humanização assistência aos pacientes graves. 375 p., Editora Atheneu, 1 edição, 2008.

KOMESSU, J.H. Assistir familiares de pacientes fora de possibilidades terapêuticas; competências do enfermeiro. 2009. Dissertação (mestrado) - Escola de Enfermagem da Universidade de São Paulo, São Paulo. 2009.

KOURY, M.G.P. Como os habitantes da cidade de João Pessoa, Paraíba, definem as noções de perda, dor, morte e morrer. Revista Sociologia da Emoção, vol. 8, n. 23, p. 256-290, João Pessoa, 2009.

KOVÁCS, M.J. Desenvolvimento da Tanatologia: estudos sobre a morte e o morrer. Paidéia, vol. 18, n. 41, p. 457-468, Ribeirão Preto, 2008.

KOVÁCS, M.J. Educação para a morte, Cap. 3, p. 45-76, In: SANTOS F.S. (Org.). Cuidados paliativos: Discutindo a vida, a morte e o morrer. 1 ed., São Paulo: ATENEU, 447 p., 2009.

KOVÁCS, M.J. Educação para a morte: desafio na formação de profissionais de saúde e educação. São Paulo: Casa do Psicólogo: FAPESP, 180 p., 1 ed., 2003.

KOVÁCS, M.J. Psicologia ciência e profissão. Educação para a morte. vol. 25, n. 3, p. 484-497, Brasília, 2005. 
KREITZSCHITZ, K.; MACPHERSON, C.C. End of life care. Perspectives from families and caregivers. West Indian medical Journal, vol. 52, n. 4, p. 311-316, Dec. 2003.

LACERDA, M.R.; OLINISKI, S.R. O familiar cuidador e a enfermeira: desenvolvendo interações no contexto familiar. Acta Scientiarum. Helt Sciences. Maringá: Eduem, vol. 26, n. 1, p. 239-248, 2004.

LEAL, D.T.; FIALHO, F.A.; DIAS, I.M.A.V.; NASCIMENTO, L.; ARRUDA, W.C. Diabetes na infância e adolescência: o enfrentamento da doença no cotidiano da família. HU Revista, vol. 35, n. 4, 2009.

LEVY, M.M.; McBRIDE, D.L. End-of-life care in the intensive care unit: state of the art. in. Critical Care Medicine, vol. 34 (11 Suppl):S306-8. Nov. 2006.

LIMA, A.B.; ROSA, D.O.S. O sentido de vida do familiar do paciente crítico. Revista da Escola de Enfermagem da USP, vol. 42, n. 3, p. 547-53, 2008.

LINS, R.R. Análise das atitudes de familiares, médicos e enfermeiros a respeito das decisões de tratamento final em pacientes na UTI. 2007, 95 p., Tese (Doutorado), Fundação Antônio Prudente, São Paulo, 2007.

LISBOA, M.L.; CREPALDI, M.A. Ritual de despedida em familiares de pacientes com prognóstico reservado, Paidéia, vol.13, n. 25, p. 97-109, 2003.

LOWEY, S.E. Letting go before a death: a concept analysis. Journal of Advanced Nursing, vol. 63, n. 2, p. 208-215, 2008.

LYNN-MCHALE, D.J.; DEATRICK, J.A. Trust between family and health care provider. Journal of Family Nursing, p. 210-230, 2006.

MAIN, J. Improving management of bereavement in general practice based on a survey of recently bereaved subjects in a single general practice. The British Journal of General Practice, vol. 50(460), p. 863-866, Nov. 2000.

MAIN, J. Management of relatives of patients who are dying. Journal of Clinical Nursing, p. 794-801, Nov. 2002.

MARENGO, M.O.; FLÁVIO, D.A.; SILVA, R.H.A. Terminalidade de vida: bioética e humanização em saúde. Revista Faculdade de Medicina de Ribeirão Preto, vol. 42, n. 3, p. 286-93, 2009.

MARTINS, J.; BICUDO, M.A.V. A pesquisa qualitativa em psicologia: fundamentos e recursos básicos. São Paulo, ed. Centauro, 2005. 
MARTINS, J; BICUDO, M.A.V. Estudos sobre existencialismo, fenomenologia e educação. 112 p., ed. Centauro, São Paulo, 1983.

MARUITI, M.R.; GALDEANO, L.E. - Necessidades de familiares de pacientes internados em unidade de cuidados intensivos. Acta Paulista de Enfermagem, vol. 30, n. 1, p. 37-43. 2007.

MCCONNELL-HENRY, T.; CHAPMAN, Y.; FRANCIS, K. Husserl and Heidegger: exploring the disparity. International Journal of Nursing Practice., vol.15, n. 1, p. 7-15, 2009.

MENDES, J.A.; LUSTOSA, M.A.; ANDRADE, M.C.L. Paciente terminal, família e equipe de saúde. Revista da Sociedade Brasileira de Psicologia Hospitalar, vol. 12, n. 1, jun. 2009.

MERIGHI, M.A.B.; CARVALHO, M.V.B. O cuidar no processo de morre com dignidade. In: PIMENTA, C. A.M.; MOTA, D.D.C.F.; CRUZ, D.A.L.M. Dor e cuidados paliativos: enfermagem, medicina e psicologia. Barueri, São Paulo: Manole, 498 p. 2006.

MERIGUI, M.A.B. Fenomenologia. In: Merigui M.A.B., Praça N.S. Abordagens teórico-metodológicas qualitativas: a vivência da mulher no período reprodutivo. Rio de Janeiro: Guanabara Koogan, p. 31-38. 2003.

MILIORINI J.P.; FERNANDES M.V.; DECESARO M.A.; MARCON S.S. A família no contexto hospitalar: apreendendo os anseios e expectativas relacionadas com a doença crônica. Revista Rene Fortaleza, vol. 9, n. 3, p. 81-91, jul./set. 2008.

MINAYO, M.C.S. O desafio do conhecimento: pesquisa qualitativa em saúde. 9ª edição. Edit. Hucitec, São Paulo, 2006.

MORAN, D. Introduction to phenomenology. London: Routledge. 2000.

MOREIRA V. Possíveis contribuições de husserl e heidegger para a clínica fenomenológica. Psicologia em Estudo, vol. 15, n. 4, p. 723731, Maringá, out./dez. 2010.

MOREIRA, R.C.R.; LOPES, R.L.M.A; SANTOS, N.A. Entrevista fenomenológica: peculiaridades para la producción científica en enfermería. Index de Enfermería, vol. 22, n. 1-2, p. 107-110, 2013.

OLIVEIRA, E.A.; VOLTARELLI, J.C.; SANTOS, M.A.; MASTROPIETRO, A.P. Intervenção junto à família do paciente com alto risco de morte. Revista Faculdade de Medicina de Ribeirão Preto. vol. 38, n. 1. ano 05, Ribeirão Preto, 2005. 
OLIVEIRA, S.G.; QUINTANA, A.M.; DENARDIN-BUDÓ, M.L.; MORAES, N.A.; LÜDTKE, M.F.; CASSEL, P.A. Internação domiciliar do paciente terminal: o olhar do cuidador familiar. Revista Gaúcha Enfermagem, Porto Alegre, vol. 33, n. 3, set. 2012.

PARKES, C.M. Amor e perda: raízes do luto e suas complicações. São Paulo: Summus, 2009.

PEREIRA, L.L.; DIAS, A.C.G. O familiar cuidador do paciente terminal: o processo de despedida no contexto hospitalar, Psico, Porto Alegre, PUCRS, vol. 38, n. 1, p. 55-65, jan./abr. 2007.

PESSINI, L. Distanásia: algumas reflexões bioéticas a partir da realidade brasileira. Capit. 22 in: SANTOS F.S Cuidados paliativos: discutindo a vida, a morte e o morrer. Ed. Atheneu, São Paulo. 2009.

PESSINI, L. Eutanásia: por que abreviar a vida? Editora Loyola, 376 p., 2004.

PESSOA, R.L. O estudo da morte na formação do enfermeiro: percepção de estudantes. Dissertação Mestrado, Universidade Federal do Rio Grande do Norte, 85 p., 2012.

POPE C.; MAYS N. Pesquisa qualitativa na atenção à saúde. 3 ed., ARTMED, 2009.

QUINTANA, A.M.; KEGLER, P.; SANTOS, M.S.; LIMA, L.D. Sentimento e percepções da equipe de saúde frente ao paciente terminal. Paidéia. vol. 16, n. 35, Ribeirão Preto, 2006.

RABOW, M.W.; HAUSER, J.M.; ADAMS, J. Supporting Family Caregivers at the End of Life "They Don't Know What They Don't Know". Journal of the American Medical Association (JAMA), vol. 291, n. 4, Jan. 2004.

RITTER, R.S.; STUMM, E.M.F.; KIRCHER, R.M. Análise de Burnout em profissionais de uma unidade de emergência de um hospital geral. Revista Eletrônica de Enfermagem, vol. 11, n. 2, p. 236-48, 2009.

ROSA A.C.; STURZA, J.M. Limites e possibilidades para assegurar o direito à saúde ao paciente oncológico: estudo acerca das decisões do tribunal de justiça do Rio Grande do Sul. Direito em debate, revista do departamento de ciências jurídicas e sociais da UNIJUI. n. 39, p. 41-59, Jan-Jun 2013.

ROSENBAUM, M.E.; LOBAS, J.; FERGUSON, K. Using Reflection Activities to Enhance Teaching about End-of-Life Care. Journal of Palliative Medicine, vol. 8, n. 6, p.1186-1195, 2005. 
SALES C.A. O ser-no-mundo e o cuidado humano: concepções heideggerianas. Revista enfermagem. UERJ; vol. 16, n. 4, p. 563568, Rio de Janeiro, out/dez 2008.

SALES C.A., GROSSI A.C.M., ALMEIDA C.S.L., SILVA J.D.D., MARCON S.S. Cuidado de enfermagem oncológico na ótica do cuidador familiar no contexto hospitalar. Acta Paulista de Enfermagem, vol. 25, n. 5, p. 736-42, 2012.

SALMAZO-SILVA, H., ZEMUNER, M.N., RODRIGUES, P.H.S., ANDRADE, T.B., MARTINIANO, V.; FALCÃO, D.V.S. As Representações da Morte e do Luto no Ciclo de Vida. Revista Temática Kairós Gerontologia, São Paulo (SP), Brasil:FACHS/NEPE/PEPGG/PUC-SP, p. 185-206, ago. 2012.

SANTA ROSA, D.O.; FONTOURA, E.G. Bioética e cuidados paliativos. In: SILVA, R.S., AMARAL, J.B., MALAGUTTI, W. (Org.). Enfermagem em cuidados paliativos cuidando para uma boa morte. Cap. 4, p. 59-76. Editora Martinari, São Paulo, 2013.

SANTANA J.C.B. Avanços tecnológicos e os limites dentro de uma unidade de Terapia Intensiva no processo ético do cuidar: significado para os acadêmicos de enfermagem. Revista Bioethikos. Vol. 2, n. 1, p. 73-80, 2008.

SANTOS E.M.; SALES C.A. Familiares enlutados: compreensão fenomenológica existencial de suas vivências. Texto Contexto Enfermagem, Florianópolis, 20 (Esp), p. 214-222, 2011.

SANTOS F.S. Tanatologia: a ciência da educação para a vida, Cap. 1, p. 1-29. In: SANTOS F.S. (Org.). Cuidados Paliativos: Discutindo a vida, a morte e o morrer. 1 ed. SÃO PAULO: ATENEU, p. 447, 2009.

SAPADACIO C., BARROS N.F. Terapêuticas convencionais e não convencionais no tratamento do câncer: os sentidos das praticas religiosas. Interface Comum Saúde Educação, vol. 13, n. 30, p. 4552, 2009.

SILVA, A.R.B. Convivendo com o câncer ginecológico avançado: em foco a mulher e seus familiares. Tese doutorado, Universidade de São Paulo - Escola de Enfermagem, p. 211, São Paulo, 2002.

SILVA, A.S.A. Sussurros ao falar da morte: a significação da morte na senescência. Revista Temática Kairós Gerontologia,15(4), "Finitude/Morte \& Velhice", p. 273-294. São Paulo (SP), Brasil: FACHS/NEPE/PEPGG/PUC-SP, Agosto, 2012.

SILVA, J.M.O.; LOPES, R.L.M.; DINIZ, N.M.F. Fenomenologia. Revista Brasileira de Enfermagem, Brasília, vol. 61, n. 2, p. 254257, abr. 2008. 
SOARES, M. Cuidando da família de pacientes em situação de terminalidade internados na unidade de terapia intensiva. Revista Brasileira de Terapia Intensiva, vol.19, n. 4, 2007.

SOUZA L.G.A, BOEMER M.R. O cuidar em situação de morte: algumas reflexões. Medicina (Ribeirão Preto), Simpósio: Morte: valores e dimensões, Capítulo VII. p. 49-54, Ribeirão Preto, 2005.

SOUZA, R.P. Identificação e abordagem inicial do sofrimento. In: Cuidados paliativos nas unidades de Terapia intensiva, organizadora: Raquel Duarte Moritz. São Paulo. Editora Atheneu, 2012.

SPICHIGER, E. Living with terminal illness: patient and family experiences of hospital end-of-life care. In: Journal Palliative Nurse, vol.14, n. 5, p. 220-228, May. 2008.

STARKS, H.; BACK, L.A.; PEARLMAN, R.A.; KOENIG, A.B.; HSU, C.; GORDON, R.J.; BHARUCHA, A. Family Member Involvement in: Hastened Death. Death studies, vol. 31, p. 105 - 130, 2007.

STEINHAUSER, K.E.; CLIPP, E.C.; MCNEILLY, M.; CHRISTAKIS, A.N.; MCINTYRE, L.M.; TULSKY, J.A. In Search of a Good Death: Observations of Patients, Families, and Providers. Annals of Internal Medicine, vol. 132, n.10, p. 825-932, May 2000.

TENO, J.M.; CLARRIDGE, B.R.; CASEY, V.C.; WELCH, L.C.; WETLE, T.; SHIELD, R.; MOR, V. Family Perspectives on End-ofLife Care at the Last Place of Care. Journal of the American Medical Association (JAMA), vol. 291(1), p. 88-93, 2004.

TRINCAUS, M.R.; CÔRREA, A.K. A dualidade vida-morte na vivência dos pacientes com metástase. Revista da Escola de Enfermagem USP, vol. 41, n. 1, p. 44-51, São Paulo, 2007.

TURATO, E.R. Tratado de metodologia da pesquisa clinicoqualitativa. Petrópolis: Vozes, 685 p. 2003.

VICTOR, A.C.S; MATSUDA, L.M.; SAALFELD, S.M.S.; ÉVORA, Y.D.M Comunicação verbal de uma equipe médica: percepções e necessidades de visitantes de uma UTI. Acta Scientiarum. Health Science. vol. 25, n. 2, p. 199-206, Maringá, jul.-dez. 2003.

VIEIRA, J.M.; MATOS, K.A.P.; ANDRADE-BARBOSA, T.L.; XAVIERGOMES, L.M. Sentimentos vivenciados por familiares de pacientes internados há centro de terapia intensiva adulto. Revista Cubana de Enfermagem, Havana, vol. 29, n. 1, mar. 2013.

VISHNEVSKY T.; BEANLANDS $H$. Interpreting research in nephrology nursing: Qualitative research. Nephrology Nursing Journal, vol. 31, n. 2, p. 234-238, 2004. 
WALSH, F.E.; McGOLDRICK, M. Morte na Família Sobrevivendo às Perdas. Tradução: ROLLAND J., ARTMED, Porto Alegre, 1998.

WENRICH, M.D.; CURTIS, R.; SHANNON, S.E.; CARLINE, J.D.; AMBROZY, D.M.; RAMSEY, P.G. Communicating With Dying Patients Within the Spectrum of Medical Care From Terminal Diagnosis to Death. Arch Internal Medicine, vol. 161, Mar. 2001.

WERLE, M.A. A angústia, o nada e a morte em Heidegger. Trans/Form/Ação, vol. 26, n. 1, p. 97-113, São Paulo, 2003.

WIEGAND, L.M.H. Withdrawal of life-sustaining therapy after Sudden, unexpected life-threatening illness or Injury: interactions between patients' families, Healthcare providers, and the healthcare system. American Journal of Critical Care, vol.15, n. 2, p.178-187, Mar. 2006.

WILLARD, C.; LUKER, K. Challenges to end of life care in the acute hospital setting. Palliative Medicine, vol. 20, n. 6, p. 611-615, September 2006.

WRIGHT, L.; LEAHEY, M. Enfermeiras e famílias: um guia para avaliação e intervenção na família. 3ํㅡㄹ. Edão Paulo: Roca, 2002.

WRIGHT, L.M. Softening Suffering Through Spiritual Care Practices: One Possibility for Healing Families. Journal of Family Nursing, vol. 14, n. 4, p. 394-411, Nov. 2008.

ZAYAS, G.N. Cómo atender a la familia del enfermo. Revista Cubana de Medicina General Integral, vol. 22, n. 1, mar. 2006. 


\section{APÊNDICE A}

\section{TERMO DE CONSENTIMENTO LIVRE E ESCLARECIDO}

Eu, Isabel Comassetto, enfermeira, docente da Universidade Federal de Alagoas - UFAL e aluna do Programa Interunidades de Doutoramento em Enfermagem da Escola de Enfermagem da Universidade de São Paulo - EEUSP, estou realizando a pesquisa intitulada "Tempos difíceis: a vivência do familiar cuidador no processo de morrer no contexto hospitalar", orientada pela Prof. Dra. Ana Cristina Mancussi e Faro e convidamos você a participar como colaborador voluntário do nosso estudo.

Esta pesquisa buscará compreender a sua experiência de acompanhar a situação do seu familiar atualmente. Para tanto serão realizadas duas entrevistas com você, previamente agendadas, em local de sua escolha, que serão gravadas em áudio.

Durante todo o período da pesquisa você tem o direito de tirar qualquer dúvida ou pedir qualquer outro esclarecimento, bastando para isso entrar em contato, com a pesquisadora. Será garantido sigilo e anonimato quanto aos dados que possam identificar os colaboradores, evitando qualquer tipo de constrangimento quanto aos resultados coletados. As informações serão divulgadas apenas em eventos ou publicações científicas. Você poderá retirar seu consentimento, em qualquer fase da pesquisa sem penalização alguma a você ou ao seu familiar.

O termo é assinado em duas vias, devendo uma delas permanecer com você e a outra com a pesquisadora.

Esclarecemos que não está prevista qualquer remuneração aos colaboradores pela participação na pesquisa e que em caso de desconforto emocional você poderá ser encaminhado a atendimento psicológico nesta instituição.

Caso sinta necessidade de contatar a pesquisadora, poderá fazêlo através do telefone (82) 88831260 ou pelo E-mail: icomassetto@usp.br. Caso sinta necessidade de contatar o Comitê de Ética e Pesquisa da Escola de Enfermagem da Universidade de São Paulo, poderá fazê-lo no telefone (11) 30617548 ou pelo E-mail: edipesq@usp.br

\section{CONSENTIMENTO PÓS-ESCLARECIDO}

Acredito ter sido suficientemente informado a respeito das informações que li ou foram lidas para mim. Discuti com a pesquisadora sobre minha decisão em participar deste estudo. 
Ficaram claros para mim quais são os propósitos do estudo, os procedimentos a serem realizados, seus desconfortos e riscos, as garantias de confidencialidade e de esclarecimentos permanentes. Concordo voluntariamente em participar deste estudo e poderei retirar o meu consentimento a qualquer momento, antes ou durante o mesmo, sem penalidades ou prejuízo para qualquer membro da minha família.

Maceió, de de 2013.

Assinatura do Colaborador:

Assinatura do Pesquisador: 
Anexo A

\section{ESCOLA DE ENFERMAGEM DA \\ UNIVERSIDADE DE SAO \\ PAULO - EEUSP}

\section{PAFECER CONSUBSTANCIADO DO CEP}

\section{CAEOS DO PHOULTB DE PLDOUISA}

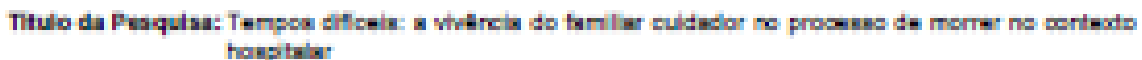

Fenplawer inatato

Are Tendiea:

Ment: 2

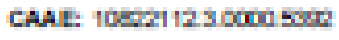

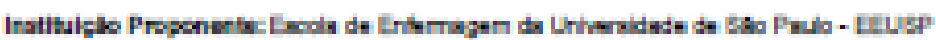

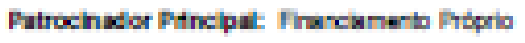

cacos CO PARLCLH

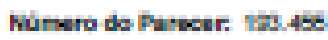

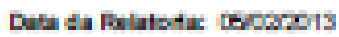

Apnsantaplo da Propk:

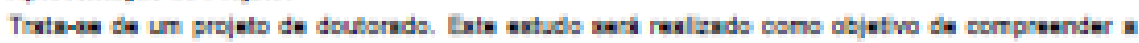

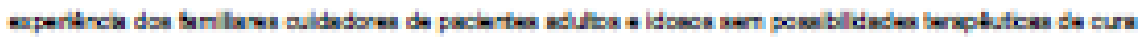

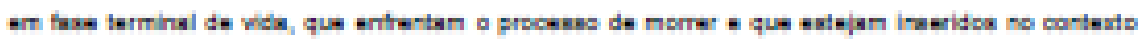

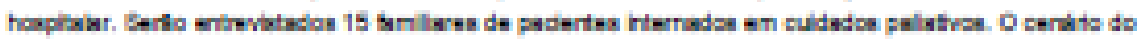

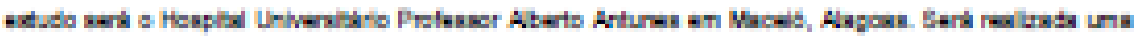

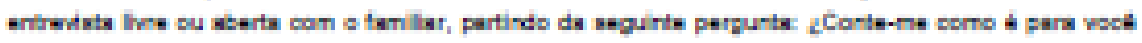

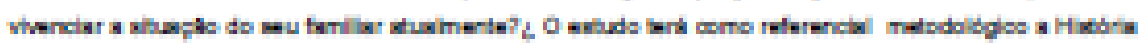
Chel inda

coptive da Finulsa:

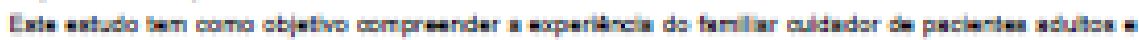

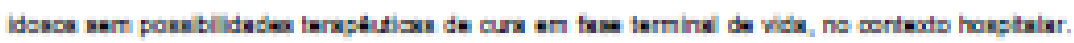

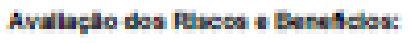

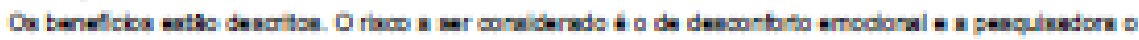

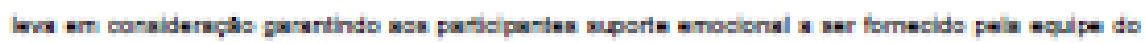

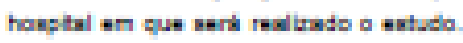

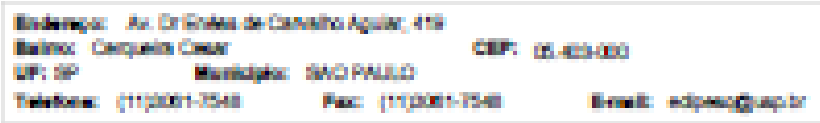




\section{ESCOLA DE ENFERMAGEM DA UNIVERSIDADE DE SAO PAULO - EEUSP}

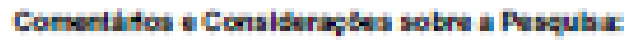

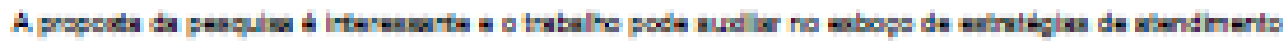

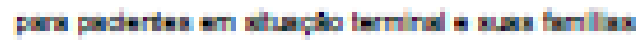

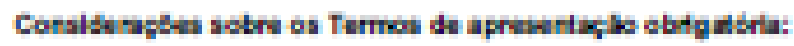

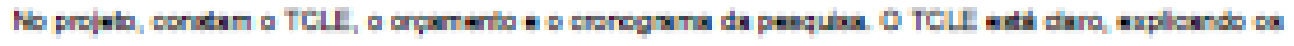

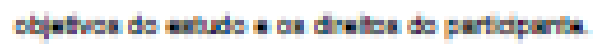

Fucomind podes:

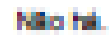

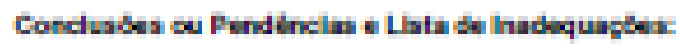

Phate aprote

Btukb ds Pancer:

Answdo

Fonsta Apreikelo do COHLF:

Ning

Corabis agha Pinuh acribib do cLP:

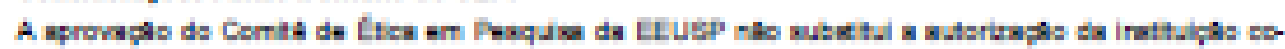

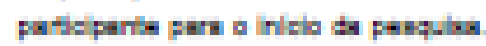

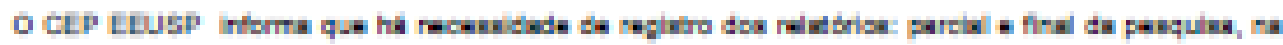
phatarna Brali.

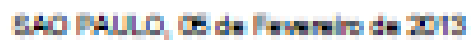

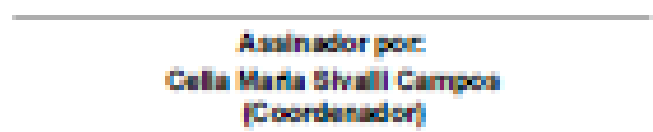

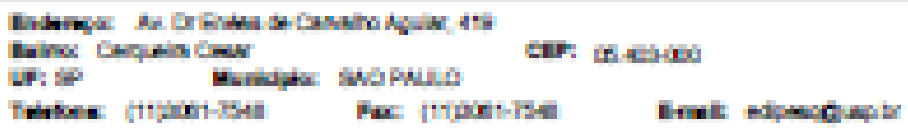

